UNIVERSIDADE DE SÃO PAULO

ESCOLA DE COMUNICAÇÕES E ARTES

CALAC NOGUEIRA SALGADO NEVES

Máquina, corpo e erotismo nos filmes

de Andy Warhol

SÃO PAULO

2017 
CALAC NOGUEIRA SALGADO NEVES

\title{
Máquina, corpo e erotismo nos filmes de Andy Warhol
}

\author{
Versão corrigida \\ (Versão original encontra-se disponível na Biblioteca da ECA-USP e na Biblioteca \\ Digital de Teses e Dissertações da USP — BDTD)
}

Dissertação apresentada à Escola de Comunicações e Artes da Universidade de São Paulo para obtenção do título de Mestre em Meios e Processos Audiovisuais

Área de Concentração: Meios e Processos Audiovisuais

Orientador: Prof. Dr. Cristian Borges 
Autorizo a reprodução e divulgação total ou parcial deste trabalho, por qualquer meio convencional ou eletrônico, para fins de estudo e pesquisa, desde que citada a fonte.

Catalogação na Publicação

Serviço de Biblioteca e Documentação

Escola de Comunicações e Artes da Universidade de São Paulo

Dados fornecidos pelo(a) autor(a)

Nogueira, Calac

Máquina, corpo e erotismo nos filmes de Andy Warhol /

Calac Nogueira. -- São Paulo: C. Nogueira, 2017.

129 p.: il.

Dissertação (Mestrado) - Programa de Pós-Graduação em Meios e Processos Audiovisuais - Escola de Comunicações e Artes / Universidade de São Paulo.

Orientador: Cristian Borges

Bibliografia

1. Andy Warhol (1928-1987) 2. Cinema Experimental I. Borges, Cristian II. Título.

CDD 21.ed. - 791.43 


\section{FOLHA DE APROVAÇÃO}

Calac Nogueira Salgado Neves

Máquina, corpo e erotismo nos filmes de Andy Warhol

Dissertação apresentada à Escola de Comunicações e Artes da Universidade de São Paulo para obtenção do título de Mestre em Meios e Processos Audiovisuais.

\section{Banca Examinadora}

Prof. Dr.:

Instituição:

Assinatura:

Prof. Dr.

Instituição:

Assinatura:

Prof. Dr.

Instituição:

Assinatura: 


\section{Agradecimentos}

Ao Cristian, pelo acolhimento, a abertura, o diálogo e a orientação tranquila.

Ao Prof. Dr. Carlos Adriano e à Prof.a Dra. Monica Tavares, pela leitura atenta do relatório de qualificação e pelas ideias estimulantes.

Aos colegas do Programa de Pós-Graduação em Meios e Processos Audiovisuais, pela amizade e troca intelectual, em especial Edson Costa, Lucas Baptista, Maria Chiaretti, João Vitor Leal, Pedro Faissol, Raul Arthuso e Tainah Negreiros.

À Livia Lima, pela revisão e por tornar os últimos meses de escrita menos solitários.

Aos meus pais, pelo apoio imenso, sempre.

À Capes (Coordenação de Aperfeiçoamento Pessoal de Nível Superior), pela bolsa concedida. 
NOGUEIRA, C. Máquina, corpo e erotismo nos filmes de Andy Warhol. 2017. 132

p. Dissertação (Mestrado) - Escola de Comunicações e Artes, Universidade de São Paulo.

\section{RESUMO}

O trabalho discute os filmes realizados por Andy Warhol entre 1963 e 1969. No primeiro capítulo, "A máquina", discutimos algumas questões mais gerais e teóricas sobre a passagem de Warhol pelo cinema, em especial a constituição de um estilo impessoal e maquínico, que o artista parece trazer diretamente de sua prática anterior na pintura. No segundo capítulo, "Corpo, superfície e erotismo", observaremos como essa máquina atua na prática, submetendo os corpos filmados a um rígido dispositivo, trazendo à tona reflexões sobre temas como a performance e o erotismo nesses filmes.

Palavras-chave: Warhol, Andy (1928-1987); cinema experimental; erotismo

\section{ABSTRACT}

NOGUEIRA, C. Máquina, corpo e erotismo nos filmes de Andy Warhol. 2017. 132 p. Dissertation (Masters) - Escola de Comunicações e Artes, Universidade de São Paulo.

The present work is focused on the films directed by Andy Warhol between 1963 and 1969. On the Chapter 1, "The Machine", we'll deal with more wide and theoretical questions concerning Warhol's itinerary through cinema, in particular the setting up of an impersonal and machinic style brought to cinema by the artist from his previous practice on painting. On the Chapter 2, "Body, Surface and Eroticism", we'll see how this machine works in practical terms by subduing the bodies to its rigid apparatus, bringing out issues such as the performance and the eroticism in those films.

Keywords: Warhol, Andy (1928-1987); experimental cinema; eroticism 


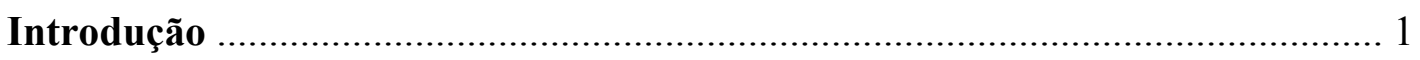

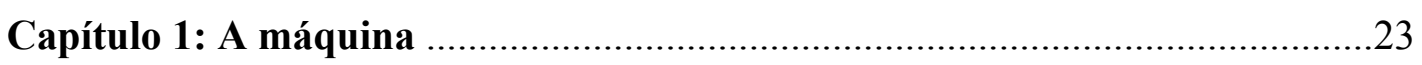

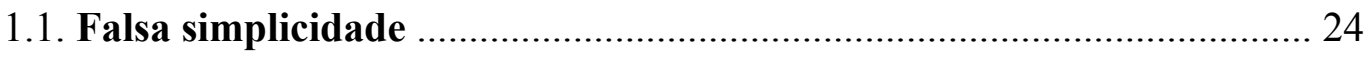

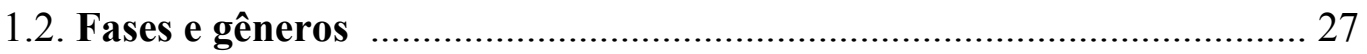

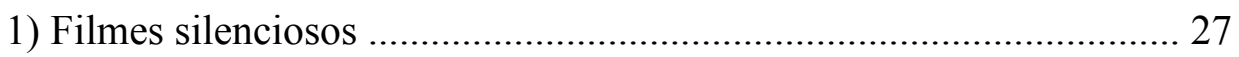

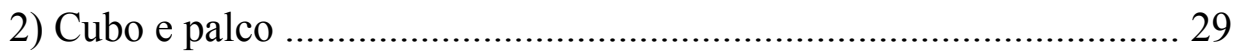

3) Arquétipos e sexplotation ………………………………………........ 31

Filmes-retratos ……………………………………………….... 35

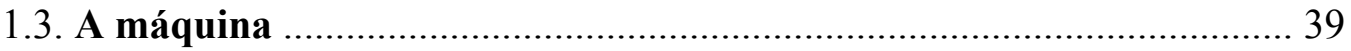

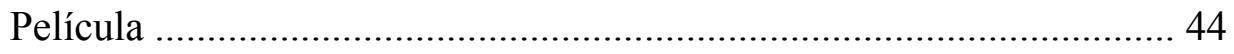

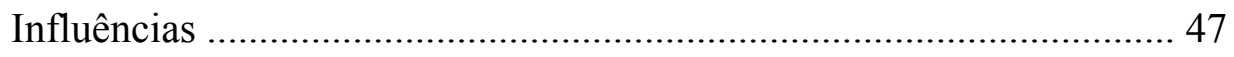

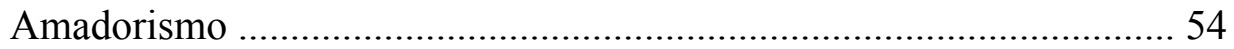

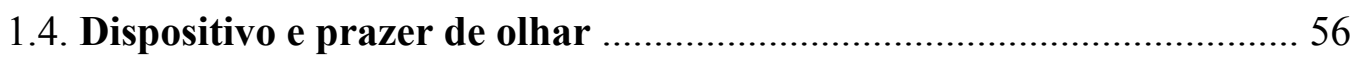

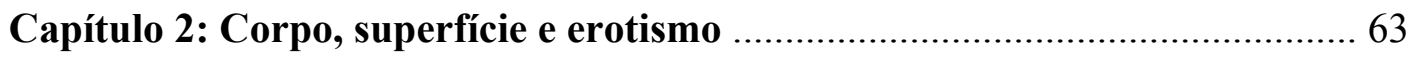

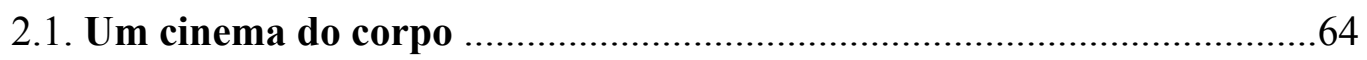

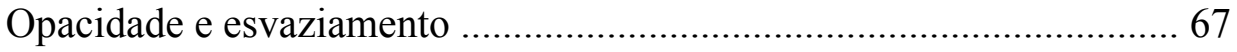

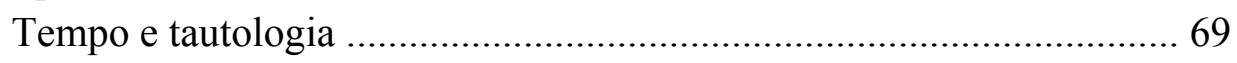

Cinema materialista ..............................................................................

Performance e presença …………………………………………..... 75

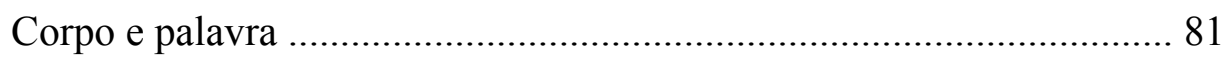

Histórias do corpo: Vinyl e I, a Man ..................................................... 84

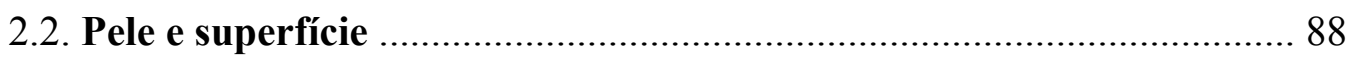

Sentido de superfície .............................................................................. 91

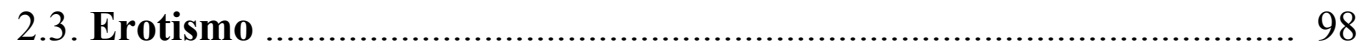

Objetificacão e voyeurismo ………………………………........... 102

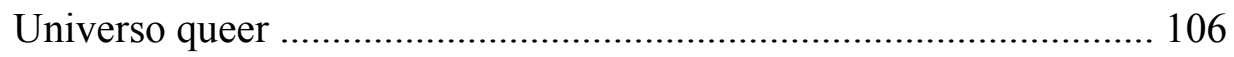

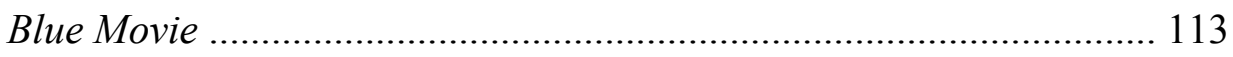

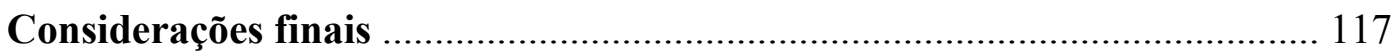

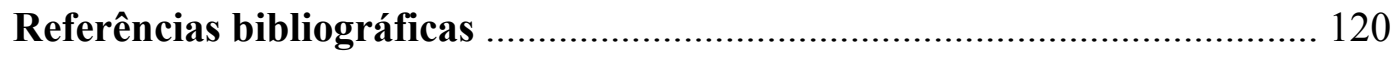

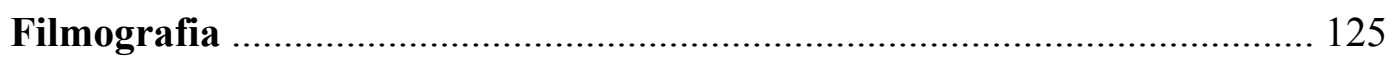




\section{Introdução}

Embora por muito tempo tenham sido vistos como uma produção marginal dentro da obra de Andy Warhol, os filmes ocuparam um espaço significativo no trabalho do artista nos anos 1960. Foram dezenas e dezenas filmes das mais diversas durações, entre obras acabadas e inacabadas, ultrapassando em muito a marca das centenas se contarmos os famosos Screen Tests, pequenos filmes com duração de um rolo $16 \mathrm{~mm}$ de cerca de três minutos, rodados com praticamente qualquer um que aparecesse na Factory. ${ }^{1}$ Do ponto de vista do volume de produção, Warhol tem lugar assegurado entre os realizadores que mais filmaram, o que é surpreendente se considerarmos o pouco tempo que dedicou ao cinema: o grosso da produção foi realizada de 1963 a 1968, quando Warhol sofre a tentativa de assassinato por Valerie Solanas em seu estúdio. Após esse episódio, o artista filmaria ainda algumas produções tardias, entre as quais Blue Movie (1969) e L'Amour (1972), dando aqui por encerrada sua passagem pelo cinema.

Os filmes aparecem em meio a um período decisivo de sua carreira como artista plástico. Embora já pintasse e viesse expondo desde meados dos anos 1950, é apenas no início dos anos 1960, com a ascensão do pop no mundo da arte, que o nome do artista passa a ganhar projeção. O ano de 1962 parece particularmente decisivo em sua trajetória. É nesse ano que Warhol consegue realizar suas primeiras exposições individuais. Na primeira delas, em Los Angeles, na galeria Ferus, expôs pela primeira vez as latas de sopa Campbell que, mesmo se bastante criticadas à época, acabariam por criar o ruído necessário para alavancar a publicidade em torno de seu nome no mundo da arte. Na segunda, em novembro, na galeria Stable, em Nova York, apresentou os primeiros trabalhos em serigrafia, técnica que criaria uma mudança profunda em seu estilo como pintor, tornando-se sua grande marca estilística. Entre as serigrafias exibidas na Stable, estavam justamente algumas das hoje famosas telas de Marilyn Monroe, realizadas imediatamente após a morte da atriz e que marcariam o início da célebre Disaster Series

\footnotetext{
${ }^{1}$ Sem contar Screen Tests, existem hoje cerca de 50 títulos da filmografia de Warhol disponíveis para circulação. É difícil, no entanto, estipular o número preciso de filmes realizados pelo artista, uma vez que nem todos eram finalizados e apresentados a público em sua época. A ideia do "filme acabado", contudo, nos parece um critério artificial e pouco produtivo para se lidar com a produção cinematográfica de Warhol, para quem os filmes eram resultado de uma relação orgânica, em algumas épocas diária, com o fazer artístico. Optamos então por inscrever a marca da imprecisão no texto. Quanto aos Screen Tests, eles são de longe a produção mais volumosa na obra do Warhol cineasta. No catálogo da exposição Andy Warhol: Motion Picures, no KW Institute for Contemporary Art, em Berlim, em 2010, eles são estimados por Thomas Sokolowski, então diretor do The Andy Warhol Museum, em nada mais nada menos do que 500.
} 
(1962-1964) — série à qual viriam se juntar as telas de Jackie Kennedy, os acidentes de carro, as cadeiras elétricas, num dos conjuntos mais ressonantes de toda a obra de Warhol. Vista de hoje, portanto, entre o fim de 1962 e o início de 1963, a carreira do artista parecia ter atingido um equilíbrio notável entre maturação artística e reconhecimento significativo no mundo da arte.

É em julho de 1963 que Warhol adquire sua primeira câmera, uma Bolex 16mm. As primeiras produções começam já no segundo semestre desse ano: Kiss (1963-64), Sleep (1963), Eat (1963), entre outros. Na mesma época, fim de 1963, Warhol muda seu ateliê para a primeira sede da Factory, ambiente que teria grande peso em sua breve mas intensa passagem pelo cinema. Mais do que um simples ateliê, a Factory se tornaria um lugar de convivência, atraindo a fauna de indivíduos que eventualmente viria a figurar nos filmes de Warhol. O local funcionaria como um pequeno estúdio independente, e se há uma experiência dentro do cinema de vanguarda norte-americano que mimetiza, à maneira de um pastiche, o sistema de estúdios de Hollywood (produção em massa, local próprio de filmagem, estrutura hierarquizada com funcionários fixos, divisão das tarefas, fluxo de trabalho diário e contínuo), sem dúvida ela pode ser encontrada na Factory. Com ela, ao longo da década de 1960 o cinema tomaria uma importância cada vez maior na carreira de Warhol.

Entre 1963 e 1964, a produção de filmes e de telas coexistem a todo vapor na Factory. O ano de 1964 é ainda de notável diversificação no trabalho de Warhol como artista plástico: é quando ele realiza as caixas Brillo, o painel encomendado, mas recusado, 13 Most Wanted $M^{2}{ }^{2}$ e inicia a série Flowers. Como é de se imaginar, nenhum retorno financeiro vinha dos filmes. Na prática, a Factory continuava a ser sustentava pelas telas, inclusive alguns retratos feitos sob encomenda - um dos mais famosos hoje é Ethel Scull 36 Times (1963). Os filmes, quando muito, asseguravam um certo burburinho em torno do nome do artista, mesmo que não fossem vistos por quase ninguém. Eles ganham significativamente mais espaço em 1965, quando sua obra como artista plástico atravessa um certo esgotamento. É o ano em que Warhol anuncia que “desistiu da pintura". ${ }^{3}$ Dessa época, destacam-se os filmes em colaboração com o então

\footnotetext{
${ }^{2}$ No início de 1964 foi encomendado a Warhol um painel para ocupar a fachada do prédio da Feira Mundial de Nova York, no bairro do Queens. O artista entregou um painel composto por fotos de identificação de fugitivos da polícia, que chegou a ser instalado ao lado de um trabalho de Robert Rauschenberg. Dias depois, no entanto, ordens vindas do governador exigiram a retirada ou substituição do painel. Diante do impasse, Warhol optou por cobrir tudo de cinza (BOCRKIS, 2003, p. 416).

${ }^{3}$ Cf. BOCRKIS, 2003, p. 512; BERG, 1989, p. 54. Na verdade, Warhol nunca parou de pintar, mas a produção de 1965 é bastante escassa.
} 
dramaturgo iniciante Ronald Tavel (Vinyl, Kitchen, The Life of Juanita Castro, todos de 1965) e, sobretudo, com Edie Segdwick, sua musa inspiradora, com quem Warhol fez um punhado de filmes e manteve uma breve e intensa amizade. ${ }^{4}$ Em 1966, apesar de uma exposição individual na galeria Lou Castelli, os maiores êxitos vêm de empreitadas laterais, como o agenciamento do Velvet Underground e o sucesso de público de Chelsea Girls (1966), que alcançou projeção e retorno financeiro como nenhum outro filme de Warhol jamais conseguiria.

Embora Warhol tenha passado por diversas práticas artísticas, os filmes constituem um conjunto relativamente coeso e fechado no interior de sua obra. Sem entrar no debate mais profundo sobre a especificidade do meio, o fato é que os filmes eram concebidos mais como um projeto paralelo - que foi ganhando cada vez mais espaço do que como algo a ser apresentado junto com as telas. Até onde se sabe, em sua época, os filmes de Warhol nunca foram projetados em galerias. Esse fato, evidentemente, precisa ser colocado em seu tempo: a noção de "artista multimídia" não era institucionalizada nos anos 1960 como é hoje e a prática de "filmes de galeria" se tornaria mais comum a partir dos anos 1970, com o fenômenos como o cinema expandido e a disseminação do vídeo. Warhol vem antes disso. Nos anos 1960, ele era visto como "um pintor que fazia filmes underground", que experimentava num outro campo. Houve um pequeno flerte com o cinema expandido nas apresentações do Exploding Plastic Inevitable em 1966, em que um show do Velvet Underground era acompanhado por projeções de filmes, slides e luzes e até mesmo algumas performances no palco. Fora isso, os filmes de Warhol tinham dois destinos principais: projeções na própria Factory e exibições em salas de cinemas, via de regra na Film-Makers' Cooperative, então programada por Jonas Mekas.

Nos anos 1970, os filmes são progressivamente deixados de lado e Warhol passa a se interessar cada vez mais pelo vídeo e pela televisão. Já em 1970 ele compra sua primeira câmera de vídeo, uma Sony Portapak. Muito embora haja pontos de contato entre os filmes e a produção em vídeo, o próprio fato de o vídeo não ser exibível em cinemas naquela época demonstra que, quando passa para esse suporte, Warhol pensava mesmo em televisão. No fundo, sua crescente produção em vídeo dos anos 1970 parece acompanhar um movimento multimídia mais consciente, que encontrará seu outro braço na revista Interview, criada em 1969, mas que se estabelece apenas alguns anos mais

\footnotetext{
${ }^{4}$ A ruptura entre os dois viria já no ano seguinte, 1966. Um capítulo inteiro da Filosofia de Andy Warhol é sobre Edie, a quem Warhol se refere pelo epíteto de "Táxi”.
} 
tarde. Assim, na década de 1970, o envolvimento de Warhol com cinema é errático e se dá principalmente como produtor dos filmes realizados por Paul Morrissey: Trash (1970), Heat (1972), Flesh for Frankenstein (1973) e Blood for Dracula (1974).

Neste trabalho, nos concentraremos nos filmes que Warhol assina como diretor. Nosso interesse é estético: queremos entrever a assinatura de Warhol como diretor de cinema. Para tanto, nos concentraremos no núcleo duro de sua produção, os filmes produzidos entre 1963 e 1969, nos quais Warhol tinha envolvimento mais direto, muitas vezes operando a própria câmera. As colaborações com Paul Morrissey serão objeto de discussão, volta e meia aparecendo no texto. Mas nosso escopo se encerra em Blue Movie, filme que, como veremos ao fim de nosso percurso, condensa muitas preocupações de Warhol como diretor de cinema.

\section{Filmando pessoas}

Não é difícil observar as continuidades que os filmes de Warhol mantêm com seu trabalho como artista plástico. Como as telas, os filmes se interessam por motivos banais: Warhol pintava objetos do dia a dia, como latas de sopa e notas de dinheiro, e, em seus primeiros filmes, registrará gestos cotidianos (comer, dormir, beber, cortar o cabelo). Há um mesmo anseio anti-heroico que une filmes e telas, e que se manifesta concretamente numa abertura ao particular e ao banal. Com frequência, os filmes também desenvolvem uma veia retratista presente nas telas - o retrato é um gênero importante tanto para o Warhol pintor quanto para o Warhol cineasta. No entanto, para além dos motivos, e de maneira ainda mais decisiva, quadros e filmes partilham estilisticamente do mesmo impulso criativo em direção ao automatismo, a mesma adesão ao maquinal e ao apagamento da subjetividade do autor.

Dito isso, o que muda? A "ruptura", ou, melhor, a abertura que os filmes de Warhol realizam em sua obra toca em algo específico do cinema: diferentemente da pintura, o gesto artístico do cinema implica no encontro direto com uma realidade contingente que se apresenta diante da câmera. Essa "realidade contingente", no caso de Warhol, tomará uma forma principal: pessoas. ${ }^{12}$ Isso não é tão óbvio quanto pode soar à primeira vista. Há uma ampla tradição no cinema experimental que não tem o homem como seu centro, e dentro dela até mesmo uma parte voltada para o inorgânico, na qual

\footnotetext{
12 Devo esta constatação central ao trabalho ao meu orientador, o professor Cristian Borges, que foi o primeiro a formulá-la para mim.
} 
poderíamos citar como exemplo o chamado cinema estrutural, tendência com que Warhol mantém algumas relações, como veremos. No entanto, o cinema de Warhol é radicalmente centrando no registro de pessoas e do corpo humano. Um breve olhar sobre sua filmografia confirma que Empire (1964) é uma exceção. Seus filmes são pautados pelo encontro entre alguém que olha (a câmera) e alguém que é olhado (o corpo).

Embora a fotografia já fosse um elemento fundamental em seu trabalho como artista plástico, até aquele momento o uso de fotos era pautado sobretudo por imagens pré-existentes, trabalhadas à maneira de um ready-made, como nas serigrafias a partir de stills de filmes comerciais de Marilyn, Elvis e Liz Taylor. Para o retrato encomendado de Ethel Scull, Warhol levou-a a uma cabine de fotografia instantânea e deixou que a máquina tirasse dezenas de fotos, dando algumas poucas instruções e depois selecionando as fotos no ateliê: um método ainda muito indireto, não comparável à relação imediata que os filmes mantém com seus retratados. Assim, mesmo que boa parte dos procedimentos de Warhol no cinema possam ser vistos como análogos àqueles das serigrafias (apagamento do gesto, incorporação dos acidentes mecânicos à fatura da obra), o cinema impõe, por suas condições intrínsecas, uma nova relação ontológica com o fazer artístico em sua obra.

Os primeiros filmes, como Kiss, Eat, Blow Job (1964) e os diversos Screen Tests silenciosos, chamam atenção pelo caráter estático. São rostos e gestos cuidadosamente enquadrados, isolados em closes ups e mantidos ali, em silêncio, expostos ao tempo. À primeira vista, eles nos remetem às telas de Marilyn ou Liz Taylor, refazendo no cinema um impulso retratista já presente nos quadros de Warhol. Aqui compreendemos o ponto de vista de alguns comentadores que tendem a ler os filmes de Warhol como uma mera continuidade de sua obra como artista plástico. Esses comentadores tendem a ressaltar, de um lado, uma certa qualidade pictórica dos filmes e, de outro, a repetição da figura no tempo, que seria um correspondente fílmico à repetição serializada da figura sobre a tela. Essa analogia não é sem razão. Mas, no fundo, ela implica uma apreciação demasiadamente superficial, quase decorativa, dos filmes, ignorando justamente o que há de mais profundo neles: o fato de que os filmes de Warhol se colocam nesse lugar de limite entre a estaticidade e o movimento, criando uma estase que está o tempo todo sendo rompida por um movimento suave, discreto, que escoa dentro do enquadramento. Assim, mesmo que o tempo em Warhol seja serializado (como discutiremos no capítulo 2), é preciso analisar o que esse tempo aporta na prática, qualitativamente, a esses filmes. 
Aqui tocamos num ponto muito importante dos filmes de Warhol: pois é muito claro que o tempo desses filmes não é um tempo qualquer, mas um tempo excessivo, obstinado, ostensivo. É sua grande marca estilística no cinema. E o que resulta desse tempo inflexível, que muitas vezes excede a própria capacidade do espectador de manterse ligado ao filme, de assisti-lo do início ao fim? Diante dos filmes de Warhol, nos vemos ora com a percepção aguçada, atentos aos mínimos detalhes da imagem, ora frente a uma sensação de tédio profundo. Há os que dizem que o tempo estendido nos torna conscientes do processo, do fato de estarmos assistindo a um filme. No entanto, não é nossa intenção aqui tirar conclusões gerais sobre a experiência, excessivamente subjetiva, de uma espectatorialidade "contemplativa". Se vamos falar do tempo em Warhol, é analisando suas consequências no interior dos filmes: o tempo como estrutura formal. É verdade que não há como "sair" da espectatorialidade, e não é absolutamente nossa intenção recusar a experiência como centro de nossa apreensão dos filmes. Mas digamos que o que nos interessa aqui é menos "o que se passa com um espectador que contempla um plano fixo e monótono de meia-hora?" e mais "como o tempo excessivo de um plano sem cortes afeta a performance de um ator?".

Retornando aos desvios que o cinema traz à obra de Warhol: os filmes substituem as vedetes icônicas por vedetes reais (suas superstars, como ele gostava de chamá-las). O ícone descarnado dá lugar ao corpo concreto. O cinema de Warhol se funda no aqui e no agora, na captura de uma realidade viva que se desfaz e se refaz. Não que Warhol negligenciasse o aspecto pictórico da imagem. ${ }^{14}$ No fundo ele era, sempre foi, um "esteta", e mesmo quando escolhe "filmar pessoas" é seguindo esse mesmo impulso: registra as pessoas porque as acha bonitas. ${ }^{16}$ Mas a força vital de seus filmes reside no que eles conseguem revelar da realidade no momento em que esta é transposta para a câmera. Dissemos revelar, não inventar. Os Screen Tests não são retratos embelezadores: eles são justamente "testes" que revelam alguma coisa de seus retratados, uma verdade ou uma beleza invisível no dia a dia, a olho nu.

Nesse sentido, Warhol não estava longe de Jean Epstein, para quem a expressão máxima do cinema era a "fotogenia". Para Epstein, a fotogenia é a revelação de uma verdade e uma harmonia já contida nas coisas, mas que era amplificada e percebida

\footnotetext{
${ }^{14}$ Segundo J.J. Murphy (2002, p. 112), “para Kitchen, ele [Warhol] disse a Tavel que queria 'branco', enquanto para Chelsea Girls ele lhe disse: 'Quero duas energias... Quero preto e branco ao mesmo tempo'."

16 "Nunca encontrei ninguém que não pudesse chamar de uma beleza" (WARHOL, 2008, p. 77).
} 
através do cinema. Essa "verdade", que Epstein chama de "valor moral", reside no aspecto móvel e vivo das coisas (numa palavra: ela é a própria vida), e por isso mesmo tem no cinema sua principal máquina revelatória em potencial. ${ }^{17}$ Veremos as consequências dessa ideia da câmera como máquina revelatória quando falarmos de questões como a performance e a presença nos filmes de Warhol no capítulo 2. Por ora, sublinhamos apenas que esses filmes não são estáticos como parecem: eles lidam, ao contrário, com uma realidade fugidia que, uma vez captada, constitui o seu principal foco de interesse.

\section{Fazer cinema}

Antes de continuar, no entanto, seria interessante se perguntar: por que Warhol decidiu fazer cinema? Por que fazer cinema naquele momento? Por que explorar um outro campo, com pouca ou nenhuma garantida de retorno financeiro, no momento em que o pragmatismo o empurrava a permanecer na pintura, com suas telas começando a valer cada vez mais e o fluxo de trabalho aumentando a cada dia? Por que não se especializar? Quando decidiu experimentar-se no cinema, Warhol rigorosamente nada sabia dos processos técnicos envolvidos na produção de um filme - e mesmo depois a situação não mudaria muito: Warhol jamais deixaria de encarnar uma experiência de cinema essencialmente amadora, como discutiremos mais adiante.

De muitas maneiras, a incursão de Warhol pelo cinema se revela uma etapa coerente com a trajetória do artista. Do ponto de vista da práxis artística, ela apenas mais um movimento em sua trajetória em direção ao maquinal. O cinema seria apenas o passo seguinte à serigrafia, técnica que já acenava um duplo interesse pelo automatismo: de um lado, pela técnica do estêncil em si mesma, que suprimia parcialmente o gesto do artista e facilitava a reprodução ad infinitum da mesma imagem; de outro, pela fotografia, que exerce papel crucial na estética serigráfica de Warhol (a obra como "testemunho" mais do que como expressão, ${ }^{18}$ o congelamento assombrado do fotográfico: o uso da fotografia

\footnotetext{
${ }^{17}$ Epstein (1974, p. 138): "Dizia há pouco: é fotogênico todo aspecto cujo valor moral é aumentado pela reprodução cinematográfica. Digo agora: apenas os aspectos móveis do mundo, das coisas e das almas podem ter seu valor moral amplificado pela reprodução cinematográfica".

${ }^{18}$ Segundo Thierry De Duve (1989, p. 6), a obra de Warhol "não promete nada; ela testemunha [...]. Mas testemunhar não é nem prometer nem simplesmente expor; é atestar a realidade como ela é, no passado ou no presente. É também reabrir as possibilidades de interpretar essa realidade e forçar uma nova tradução dela; e, no caso de Warhol, testar as possibilidades de uma condição artística 'abaixo' do nível da mercadoria".
} 
abre toda uma nova dimensão estética na obra de Warhol). Sabe-se que por toda a sua vida Warhol se interessou por apetrechos tecnológicos: a partir dos anos 1970, ele teria sempre à mão gravadores de voz e câmeras polaroides. Nesse projeto artístico global, portanto, o cinema é apenas mais uma entre diversas outras manifestações da famosa máxima warholiana do "I want be a machine" — uma máquina objetiva, fria, impessoal.

Por outro lado, o cinema é também o primeiro passo de Warhol num movimento de exploração multimídia que seria essencial à consolidação de sua faceta de artista empreendedor, o business artist que ele tanto comenta. A Factory e os filmes, mesmo não sendo exatamente empreendimentos comerciais, marcam o início de uma outra relação com o fazer artístico, na qual o "pintor de ofício" cede lugar à ideia do artista como personalidade aglutinadora, que gerencia um ecossistema e capitaliza em torno de si mesma. Os filmes talvez sejam o grande testemunho dessa passagem à ideia do produtor como artista, ou do artista como produtor. Mais do que uma experiência com uma outra práxis, portanto, eles representam uma abertura na obra de Warhol. São o começo de uma aventura que iria culminar na produção de festas, no gerenciamento do Velvet Underground e, a partir dos anos 1970, de publicações impressas e do vídeo para a TV.

Todavia, embora significativos, esses pontos parecem insuficientes se queremos entender o que levou Warhol a fazer cinema. Pois que as ideias do automatismo e do business artist nos dão a ver é, sobretudo, um ponto de vista exterior e teleológico sobre a trajetória do artista, um raciocínio autorista que se fecha em si mesmo, na consistência da entidade autor. Em outras palavras, a coerência artística, embora seja um dado central no movimento de Warhol para o cinema, pode até justificar, mas não explica esse movimento. O fato de um movimento ser coerente não elucida as forças que o geraram. Se quisermos, então, compreender as razões que levaram Warhol a fazer cinema, talvez seja preciso deixar o autor todo-poderoso um pouco de lado e se focar no homem.

Sem dúvida, para um artista pop como Warhol a atração pelo cinema tinha qualquer coisa de natural. $\mathrm{O}$ cinema era, naquele momento, o hábitat das estrelas que tanto serviram de inspiração para suas telas. Assim, antes mesmo de passar a realizar filmes, Warhol já "tematizava" o cinema em quadros como Eight Elvis (1963) e Cagney (1962), ambos baseados em stills publicitários de filmes e nos quais a repetição da mesma imagem representando cenas de ação chegava, inclusive, a criar uma sugestão de movimento. Em termos simbólicos, o cinema representava tanto a concretização de uma arte popular, comercial e industrial em termos que a arte pop jamais conseguiria atingir, quanto o lugar de um certo glamour que, sem dúvida, exercia atração sobre Warhol. O 
lugar onde a ilusão se tornava completa, onde era possível passar totalmente para o "lado de lá" e viver dentro da imagem: "o melhor clima em que consigo pensar é o do cinema, porque é tridimensional fisicamente e bidimensional emocionalmente", diz Warhol em sua Filosofia (2008, p. 182). No entanto, que um artista plástico se interesse e anseie pelo cinema, e que isso represente um passo coerente em sua trajetória artística, tudo is so ainda assim não explica por que Warhol, o indivíduo, passou a realizar filmes.

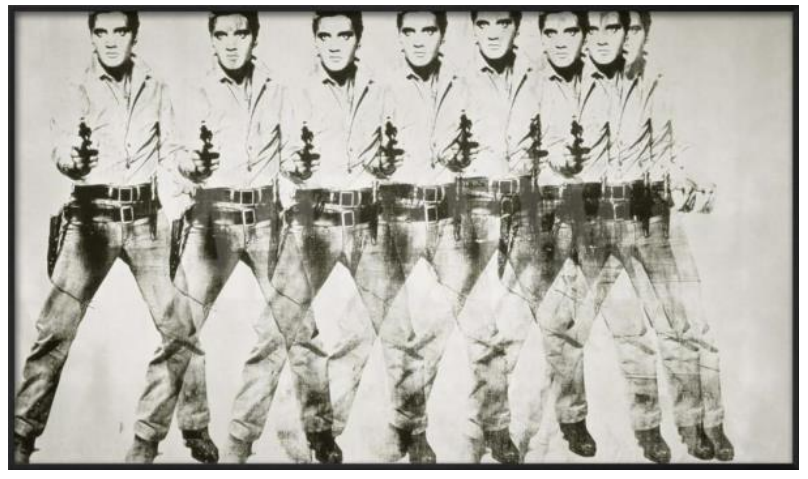

Eight Elvis (1963)

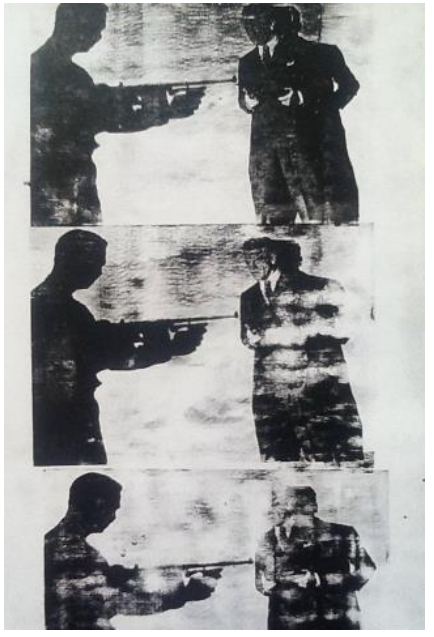

Cagney [imagem cortada] (1962)

Os filmes de Warhol despontam num contexto cultural específico: o cinema independente nova-iorquino dos anos 1950 e 60, particularmente em sua faceta underground e de vanguarda. Eles são fruto de idas à Film-Makers' Cooperative, ao Charles Theater e a outros espaços da época voltados para a exibição de filmes alternativos, bem como de uma rede de relações que envolvia artistas e cineastas. Essa "cena" era relativamente incipiente e porosa, frequentada por cineastas, artistas plásticos, músicos, poetas. Na realidade, um meio especificamente cinematográfico independente estava apenas em vias de se constituir, e nisso um homem teria papel fundamental: Jonas Mekas. Apesar do esforço anterior de figuras como Maya Deren e Amos Vogel no sentido de aproximar e associar os cineastas de vanguarda, é graças a Mekas, com as exibições na Film-Makers' Coop, suas colunas no jornal Village Voice, a revista Film Culture e sua premiação anual (o "Independent Film Award") que a ideia de um meio especificamente cinematográfico 
alternativo parece se consolidar. ${ }^{19}$ Para que haja uma "cena", é preciso não apenas que os cineastas façam filmes, mas que eles sejam exibidos, discutidos, teorizados (Sitney se incumbirá desse papel mais tarde), e é aí que o papel de Mekas como uma espécie de agitador cultural, antes de produzir sua obra mais fecunda como cineasta, se revela fundamental. É a Mekas que Warhol mostrará seus primeiros filmes, e é por meio dele que esses filmes virão a público, ganhando suas primeiras exibições públicas. É essa abertura de Mekas que legitima, por assim dizer, os filmes de Warhol como "cinema", na medida em que eles deixam de se restringir a projeções privadas na Factory e ganham o espaço público da sala do cinema, sendo articulados de um ponto de vista curatorial e exibidos junto com filmes de outros cineastas de vanguarda da época.

No entanto, a incursão de Warhol pelo cinema talvez tenha sua maior causa na porosidade do meio na época. Uma boa prova dessa porosidade é o fato de que uma grande parte dos cineastas experimentais que despontam nos anos 1960 vinha de outras práticas artísticas: Marie Menken estudara pintura; Hollis Frampton começara como fotógrafo e era muito próximo de artistas plásticos como Carl Andre e Frank Stella; Jack Smith era ao mesmo tempo cineasta, ator e performer; Michael Snow já possuía uma carreira de multi-artista no Canadá antes de chegar a Nova York; e o próprio Mekas começara como poeta antes de vir para os Estados Unidos. Isso para falar apenas daqueles que se tornaram cineastas em sentido estrito. Entre os artistas que preferiram permanecer na "fronteira", mas que passaram em maior ou menor extensão pela realização de filmes, podemos citar o artista plástico Joseph Cornell, o fotógrafo Robert Frank, o músico Tony Conrad, que colaborara nas trilhas sonoras de Jack Smith antes de realizar seu próprio filme, The Flicker (1966), George Maciunas, Yoko Ono e o grupo Fluxus, a coreógrafa Yvonne Rainer e, na costa leste, o artista plástico Bruce Conner, entre outros. Warhol faz parte dessa tradição de artistas-cineastas que, em algum momento, buscaram no cinema um meio para se expressar - e à qual poderíamos acrescentar uma longa genealogia que se estende por toda a primeira metade do século XX, que incluiria Marcel Duchamp, Hans Richter, Fernand Léger, Man Ray, entre outros. O "fetiche do cinema", seja a atração, seja a repulsão violenta que ele exerce sobre os artistas enquanto máquina produtora de imagens, é sem dúvida um tema que atravessa a arte do século XX. Warhol, como artista

\footnotetext{
${ }^{19}$ Entre os esforços de articulação podemos citar também a declaração do Novo Cinema Americano, que tinha entre seus signatários Mekas e cineastas como Robert Frank, Shirley Clark, Gregory Markopoulos, Emile De Antonio, entre outros.
} 
e vítima de seu tempo, não apenas flertará, como mergulhará de cabeça nisso. O resultado é decisivo, para ele e para o cinema.

Assim, o que importa constatar aqui é que a interpenetração do cinema de vanguarda com diversos campos artísticos na Nova York dos anos 1960 tornava, para Warhol, a realização de filmes uma possibilidade real e concreta: fazer cinema era algo palpável. No círculo pessoal de Warhol, essa possibilidade se cristalizava sobretudo em três figuras: Marie Menken, Emile De Antonio e Jack Smith. Menken e o marido, o poeta e professor Willard Maas, eram figuras conhecidas na cena artística e intelectual novaiorquina (em Popismo, Warhol se refere ao casal como "os últimos dos boêmios" [2013, p. 38]). Pintora de formação, Menken realizava pequenos filmes em $16 \mathrm{~mm}$ desde meados dos anos 1940 e tinha em seu círculo de amizades outros cineastas, como Kenneth Anger e Stan Brakhage. Ela e Warhol serão apresentados alguns meses antes de o artista se decidir a se aventurar no cinema, e consta que numa ocasião Menken inclusive chegou a instruir Warhol em como utilizar a Bolex. ${ }^{20}$

Emile De Antonio era agente de artes plásticas nos anos 1950 e um dos principais amigos de Warhol na época. Desde o início dos anos 1960, no entanto, ele passara a produzir documentários políticos, sendo os mais conhecidos hoje Point of Order (1964) e In the Year of the Pig (1968). Como o próprio Warhol relata em Popismo, De Antonio foi um dos principais responsáveis por sua aproximação com o ambiente do chamado “cinema underground", ${ }^{21}$ seja frequentando sessões na Film-makers' Coop e no Charles Theater, seja apresentando-o a figuras como Mekas, Ron Rice, o ator Taylor Mead e o fotógrafo e diretor de cinema Robert Frank (Warhol inclusive relata ter sido levado por "De" a uma sessão de dublagem de Pull My Daisy em que estavam Frank, Alfred Leslie, Jack Kerouac, entre outros).

No entanto, entre todas as figuras ao redor de Warhol que faziam cinema naquele momento, nenhuma teve mais importância para ele do que Jack Smith. Ator, performer e cineasta, Smith vinha rodando alguns filmes inacabados com Bob Fleischner desde meados dos anos 1950 — parte desse material seria futuramente montado por Ken Jacobs, resultando em Blonde Cobra (1963). Entre as primeiras imagens capturadas por Warhol com sua câmera Bolex estava justamente um making of do set de Normal Love (1963), de

\footnotetext{
${ }^{20}$ Cf. o documentário Notes on Marie Menken (2006), de Martina Kudlacek.

21 "Filme underground" era um termo muito usado na época para se referir a parte do cinema independente, como os filmes ligados à tendência beat, bem como aqueles de Jack Smith, do próprio Warhol, entre outros. O termo remete à presença de comportamentos desviantes (como uso de drogas) e sexualidade nãonormativa nesses filmes. Quando usarmos o termo, estamos recuperando esse sentido histórico.
} 
Smith, rodado numa fazenda em Old Lyme, Connecticut. Neste mesmo ano, 1963, Smith faria o papel de Drácula num filme inacabado de Warhol. Ele posteriormente apareceria também em Camp (1965) e Hedy (1966).

A influência de Smith sobre Warhol, no entanto, não se limita à esfera pessoal. É, sobretudo, em termos estéticos que parece haver entre os cineastas uma conexão, da qual Warhol é devedor. Smith está para os filmes de Warhol como Jasper Johns estava para suas telas. Como Warhol, Smith também encarna uma ideia de cinema que se resolve no set de filmagens, em que a experiência do set tem prevalência sobre os processos de pósprodução (montagem, edição de som). Vale o que se captou na filmagem, o que explica o aspecto bruto e a pouca consistência narrativa e ficcional desses filmes. Warhol irá incorporar tudo isso para dentro de seus filmes (os strobe cuts rapidamente se tornarão marcas estilísticas e as indistinções entre ator e personagem uma questão em seu cinema), ao passo que Smith trilha um caminho ainda mais radical: ele sequer se dá ao trabalho de terminar seus filmes. $\mathrm{O}$ que valia era a farra do set, mais do que qualquer outra coisa. Apesar de muito ativo nos anos 1950 e 60, pouquíssimos filmes de Smith foram finalizados. Seu único longa acabado é o célebre Flaming Creatures (1963), e mesmo este ele teria, segundo consta, "tentado mudar, e muito provavelmente destruir", ao longo dos anos (SITNEY, 2002, p. 396). Sitney nota que a entropia e o inacabamento constituem a força central do trabalho de Smith, seja em suas peças e apresentações, seja nas projeções de seus filmes, eventos "que invariavelmente começavam atrasados, interrompiam-se diversas vezes e envolviam o próprio Smith produzindo, instruindo atores, arrumando equipamentos e repentinamente mudando o curso da obra" (p. 396).

Filmados praticamente sem roteiro e sem diálogos, os filmes de Smith operam numa estética carnavalesca centrada no travestismo, encarnado tanto na própria figura da drag queen (Flaming Creatures) quanto em referências a ícones do cinema popular (a Sereia, a Múmia e a Mulher-Cobra em Normal Love). Um dos filmes inacabados que o cineasta roda ainda no fim dos anos 1950 é justamente um "remake" de Cobra Woman (1944), produção aventuresca da Universal estrelada por Maria Montez (é dela que o ator Mario Montez, ícone de diversos filmes de Warhol e intérprete principal de Normal Love, tira seu pseudônimo). No filme de Smith, no entanto, a narrativa é descartada e cede lugar a sequências performáticas e musicais que se encerram em si mesmas. Retirado da economia narrativa, o ícone (seja a drag, sejam os arquétipos da cultura pop) é esvaziado e adquire um sentido puramente decorativo. Tal qual um Paradjanov do underground e do lixo, Smith submete os corpos a um cerimonial do artifício, criando imagens chapadas 
que encarnam o que André Antônio Barbosa (2017), num trabalho recente, denomina "estética da frivolidade": uma estética superficial, ociosa, centrada no artificial e no falso.

Da relação Warhol-Smith, é preciso reter essa ideia do esvaziamento do ícone e de um sentido de superfície. Os filmes de ambos partilham de uma mesma lassidão contemplativa, uma ociosidade que esvazia as imagens de todo sentido mais profundo. A diferença reside no cerimonial a que os corpos são submetidos: lá onde Smith trabalha ornamentando o corpo com o artificial, a fantasia, o kitsch, Warhol se volta, ao contrário, para um corpo nu, absolutamente despojado, reduzido à pele. Os filmes de Smith em geral têm caráter espetaculoso e exibicionista, ao passo que os filmes de Warhol são marcados pelo voyeurismo - o cineasta é como um vampiro que suga a vida de seus intérpretesmodelos. Ainda assim, ambos se comunicam por um mesmo gosto camp, pelo interesse na performance mais do que na narrativa, pelo erotismo marginal e por uma certa fetichização da imagem em si mesma e por si mesma, dotada de um sentido autônomo, destacado da obra acabada.
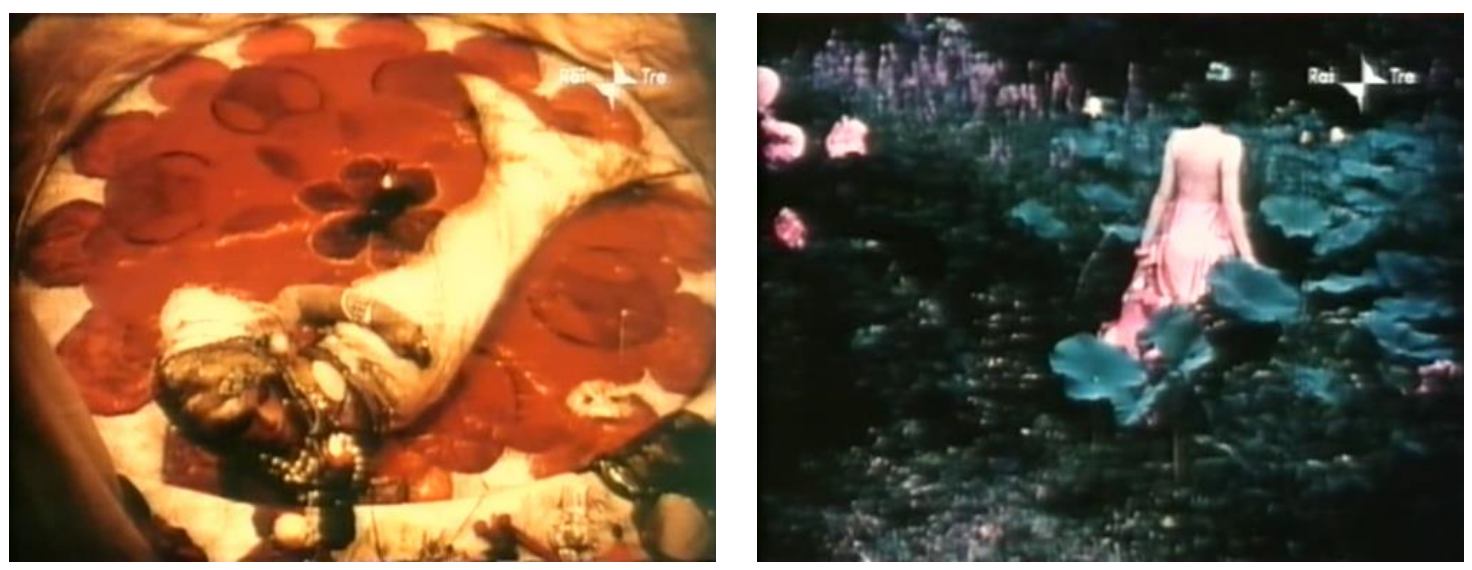

Frames de Normal Love (1963), de Jack Smith

Num trecho de Popismo, Warhol descreve um dos sets de Smith em que esteve: "Os preparativos para cada filmagem eram como uma festa - horas e horas de pessoas pondo maquiagem, vestindo figurinos e construindo cenários" (2013, p. 45). Para além do filme acabado (ou não acabado), havia nos filmes de Smith o já mencionado aspecto de farra: o cinema era também uma forma de divertir-se em grupo, travestindo-se, performando. Vendo os filmes, percebe-se que os atores também se divertem (como na cena em que os atores fantasiados de Normal Love se reúnem para comer melancia ou fumar maconha). 
Aqui gostaríamos de levantar a hipótese de se uma das razões que levaram Warhol ao cinema não foi também um interesse por esse tipo de experiência social, por uma troca coletiva ausente no ritmo solitário e introspectivo, naturalmente imposto pela pintura. "Pessoas em geral me influenciam; detesto meros objetos, eles não têm interesse algum para mim" (BERG, 1989, p. 54), ele diz numa dessas declarações que podem sempre ser negadas por outras logo adiante. À medida que a carreira de Warhol evolui, fica muito claro seu interesse por uma vida social: basta lermos seus diários, observar o afinco com que um Warhol já célebre narra os compromissos sociais, sem qualquer deslumbre, e, no entanto, transmitindo um enorme prazer naqueles encontros, em estar com pessoas.

É possível ler tudo isso (diários, vida social) pelo viés da celebridade e da autopublicidade. No entanto, como dizíamos mais acima, em sua truculência, o autorismo corre sempre o risco de mistificar e, consequentemente, de desumanizar o artista. Por trás da fama há sempre o homem. Um homem que viveu, com anseios e fraquezas tão mundanos quanto os nossos. Um homem certamente tímido, evasivo diante de conflitos, e, no entanto, movido por um enorme desejo de ser aceito, às vezes num sentido francamente arrivista. Sem querer explicar a obra através do homem, por meio de um psicologismo redutor, gostaríamos apenas pontuar o seguinte: apesar de seu fascínio pelo maquínico, Warhol amava pessoas, respirava e se alimentava delas, como deixam claro os diários, as conversas telefônicas, sua intensa vida social em geral. É nesse sentido que o cinema e a Factory podem ser vistos como a concretização de um anseio pelo encontro. A Factory como espaço de convivência por excelência, os filmes como o encontro entre alguém que filma e alguém que é filmado, entre alguém que olha e alguém que é olhado. Essa relação, evidentemente, vem sempre carregada perversidade e desejo (são incontáveis as menções em relatos à palavra "manipulador" para se referir à atuação de Warhol dentro da Factory). Mas tudo isso é também o que confere riqueza e complexidade à obra de Warhol, ao trabalho de um homem que não apenas fez de sua vida obra (o efeito celebridade), mas para o qual a obra era sua própria maneira de experimentar a vida.

\section{Estrutura do trabalho}

Nosso trabalho se estrutura em duas partes, que correspondem a seus dois capítulos. No primeiro, “A máquina”, abordaremos as relações entre os filmes de Warhol e sua carreira como artista em geral, apontando progressivamente para a descrição de um "estilo 
maquínico" que ele importa das artes plásticas e que ganha contornos específicos no cinema. Observaremos como essa "máquina" funciona na prática nos filmes e analisaremos diversos problemas conceituais levantados pela ideia de um cinema impessoal, mecânico, em que o autor dá a impressão de ter sido absorvido pelo maquinal. De certa maneira, podemos dizer que o primeiro capítulo oferece um ponto de vista "exterior" dos filmes, descrevendo-os tanto em sua estrutura externa quanto em suas relações com o contexto em que aparecem.

O segundo capítulo, "Corpo, superfície e erotismo", faz o caminho contrário: aqui trata-se de analisar o que há de fato no interior dos filmes, para além de sua fachada impessoal e maquínica. Nos deteremos sobretudo na forma como Warhol filma o corpo, o qual ocupa, a nosso ver, o centro dos filmes. Abordaremos diversos problemas relativos a esse pôr-em-cena do corpo, como as relações corpo-palavra e corpo-performance, discutindo por fim o conteúdo erótico latente que, em nossa opinião, esses filmes guardam dentro si.

Em resumo, o primeiro capítulo busca uma descrição da instância que olha (a máquina), o segundo daquilo que é olhado (o corpo). O primeiro se volta mais para problemas teóricos e questões biográficas, enquanto o segundo ensaia uma abordagem imanente dos filmes. Ele é, nesse sentido, também mais especulativo e mais pessoal. Por fim, em alguma medida, o segundo capítulo é uma negação dialética do primeiro: o primeiro afirma a máquina warholiana como "olho de vidro", o segundo procura atestar que essa máquina tem afinal uma sensibilidade e um gosto particulares.

\section{Breve revisão crítica}

Em dezembro de 1964, Jonas Mekas ofereceu a Andy Warhol o sexto Independent Film Award, premiação concedida por sua revista, a Film Culture, aos cineastas independentes da época. ${ }^{25} \mathrm{O}$ prêmio foi entregue a Warhol e sua trupe em uma mini-cerimônia na Factory, registrada por Mekas. ${ }^{26}$ Por ocasião do prêmio, Mekas também escreveu na Film Culture um dos primeiros registros críticos que se tem sobre os filmes de Warhol:

\footnotetext{
${ }^{25}$ Os premiados em outros anos foram: John Cassavetes por Shadows (1959); Robert Frank e Alfred Leslie por Pull My Daisy (1960); Ricky Leacock, Don Pennebaker, Robert Drew e Al Maysles por Primárias (1961); Stan Brakhage por The Dead and Prelude (1962); Jack Smith por Flaming Creatures (1963); entre outros.

${ }^{26} \mathrm{O}$ registro da cerimônia pode ser visto em https://vimeo.com/13327002. Acesso em 18 de novembro de 2017.
} 
Warhol está reconduzindo o cinema a suas origens, aos dias dos Lumière, a um rejuvenescimento e uma purificação. Em sua obra, ele abandonou todas a formas "cinemáticas" e adornos temáticos que o cinema havia reunido junto de si até o momento. Focou suas lentes nas imagens mais simples e da forma mais simples possível. (...) Algo estranho acontece. O mundo se torna transposto, intensificado, eletrificado. Vemo-lo mais definidamente do que antes. Não dentro de contextos e significados rearranjados, dramáticos, não a serviço de algo além (mesmo o cinema verité não escapou dessa sujeição da realidade objetiva às ideias), mas tão puro quanto ele é em si mesmo: o comer enquanto comer, o dormir enquanto dormir, o cortar o cabelo enquanto cortar o cabelo. (MEKAS, 1964, p. 1)

O mundo "tão puro quanto ele é em si mesmo". É preciso colocar as coisas em seu devido contexto. Essa pureza recuperada de que fala Mekas, embora exista nos filmes de Warhol, não é exatamente algo peculiar e restrito a ele. Antes, ela constitui um mito vanguardista que anima outros cineastas experimentais da época e, especialmente, o próprio Mekas. Um desejo de ir além dos códigos então estabelecidos pelo cinema e retornar às coisas mesmas. Lendo outros textos de Mekas do período percebemos que a ideia de um "retorno a Lumière" como expressão desse mito de pureza retorna com alguma frequência. Escrevendo sobre Pull My Daisy (1959), o filme beat de Robert Frank com roteiro de Jack Kerouac, ele também diz que o filme retorna o cinema "ao ponto em que Lumière deixou" (MEKAS, 2013, p. 57). No fundo, a ideia de um olhar puro sobre as coisas, essa busca da plenitude no banal, da beleza no "insignificante, no efêmero" (p. 72), são frutos de uma filosofia zen que informa o pensamento de Mekas como tudo e que irá pautar seus próprios filmes-diários, centrados no registro de momentos "menores", montados de maneira desierarquizada. $O$ que não quer dizer que essas características não existam nos filmes de Warhol - muito embora elas ocorram de maneira talvez menos orgânica e inocente do que Mekas sugere. Acima de tudo, há em Warhol um sentido de positividade que a fórmula de Mekas capta bem, a reivindicação da beleza num rosto em si mesmo e por si mesmo, sem "significados rearranjados, dramáticos" — uma positividade que depois seria sublinhada por Baudrillard (1997, p. 195), quando diz que em Warhol "todas as imagens são boas [...] todas as pessoas são formidáveis [...], basta fotografá-las”.

A despeito do artigo de Mekas, no entanto, a maior parte da recepção crítica de Warhol nos anos 1960 e 1970 tendia a ressaltar o aspecto "estrutural-materialista" dos filmes. Num texto também publicado na revista Film Comment, o crítico de arte Henry Geldzahler (1964, p. 13) notava que os filmes de Warhol "escondem sua arte exatamente como suas pinturas" e que neles "estamos constantemente conscientes do processo filme, 
às vezes até mesmo vendo os frames que encerram os rolos" ${ }^{27}$, algo que também será ressaltado por Peter Gidal, para quem Warhol é pura e simplesmente um "cineasta materialista" (discutiremos um pouco essa ideia no capítulo 2). Esse ponto de vista também informa, embora de modo indireto, o olhar de P. Adams Sitney, que, em seu amplo estudo sobre o cinema experimental, Visionary Film, publicado pela primeira vez em 1974, percebe Warhol como um precursor do que chama de "cinema estrutural". Falaremos melhor das aproximações entre Warhol e o cinema estrutural no capítulo 1, mas basicamente o que os aproxima, na visão de Sitney, é uma mesma postura “antirromântica" e, no caso de Warhol, uma concepção de tempo serializada que remete ao desenvolvimento por meio de padrões dos filmes estruturais.

Embora distantes, os pontos de vista de Sitney e Mekas não são excludentes, mas complementares. Elas constituem dois polos muito nítidos quando nos defrontamos com os filmes de Warhol. Por um lado, esses filmes apresentam uma estrutura rígida, calcada na serialização temporal. Por outro, eles visam a captura do mundo, da realidade contingente, que em muitos casos foge do controle do cineasta e assume uma qualidade entrópica. O que é surpreendente é que o próprio Sitney não tenha feito a relação entre esses dois polos em seu estudo: em Visionary Film (2002), o capítulo anterior a "Structural Film" se chama justamente "Recovered Innocence" [inocência recuperada]. Nele, o autor comenta alguns filmes de Ken Jacobs, Jack Smith, Joseph Cornell, entre outros, e fala de "uma confiança crescente no início dos anos 1960 no processo de compor um filme dentro da câmera", em um "método direto que encontraria seu porta-voz e um de seus principais praticantes em Jonas Mekas" (SITNEY, 2002, p. 398). Com efeito, como não notar que os filmes de Warhol se dão justamente nessa passagem entre uma "inocência recuperada" (como proposta por Mekas) e o surgimento do estrutural?

Saindo do pequeno mundo do cinema experimental, o primeiro estudo de fôlego exclusivamente sobre os filmes de Warhol publicado nos Estados Unidos foi o livro de Stephen Koch, Stargazer, de 1973. Antes dele, Peter Gidal havia publicado Andy Warhol: Films and Paintings: The Factory Years em 1971, livro que tem a particularidade de reunir as pinturas e os filmes de Warhol sob um mesmo ponto de vista "materialista", perspectiva essa que em muitos momentos parece obliterar o olhar de Gidal para o que as obras nos dão, de fato, a ver. O livro de Koch, ao contrário, é um mergulho fascinado no universo dos filmes de Warhol. Ainda que pouco sistemático e frequentemente

${ }^{27}$ Geldzahler (1964, p. 13) continua: "Uma história mais repleta de incidentes tirariam nossa atenção do fato de que estamos vendo um filme". 
aproximando a obra e traços da personalidade de Warhol (Koch visitou a Factory algumas vezes), trata-se de um dos testemunhos mais sensíveis do que os filmes de fato são, independentemente de tentativas de categorização em sistemas críticos. Foi Koch o primeiro a notar o conteúdo altamente erótico dos filmes de Warhol, bem como o contorno voyeurista de sua relação com o cinema, algo ausente no contexto das discussões da Film Culture.

Entre as perspectivas de língua não inglesa, vale mencionar os trabalhos dos italianos Adriano Aprà e Enzo Ungari e de Gilles Deleuze. Embora não cite Warhol em mais do que uma página de $A$ imagem-tempo, Deleuze estava no caminho certo quando, em sua taxonomia, posiciona Warhol entre os "cineastas do corpo". Essa perspectiva aparece também em Aprà e Ungari, que em seu estudo panorâmico Il cinema di Andy Warhol, de 1971, desenvolvem de forma certeira a ideia de um divórcio entre corpo e palavra nos filmes de Warhol, uma questão muito importante e que retornará em nosso trabalho.

É relevante o fato de que, ainda no início dos anos 1970, envolvido com outros interesses, Warhol retirou a maior parte de seus filmes de circulação. Eles só reapareceriam após sua morte, em 1987, quando se observa o surgimento de uma nova onda de publicações. ${ }^{28}$ Entre elas, destacam-se Andy Warhol: Film Factory (1989), coletânea organizada por Michael O'Pray e publicada pela BFI, em Londres, e toda a produção de Callie Angell, então diretora do Andy Warhol Film Project, autora de Something Secret: Portraiture in Warhol Films (1994) e editora dos catálogos do Whitney Museum.

A partir dos anos 1990, os estudos culturais também fariam sua entrada na obra de Warhol via teoria queer. Nessa perspectiva, sobre os filmes de Warhol em particular, destaca-se o artigo "Cockteaser" (1996), de Thomas Waugh, publicado na coletânea Pop Out: Queer Warhol (1996), e Our Kind of Movies (2012), livro de Douglas Crimp. Por fim, já fora dos estudos queer, mencionamos o livro de Steven Shaviro, O corpo cinemático, publicado originalmente em 1993 e no qual os filmes de Warhol são discutidos como parte de um quadro mais amplo proposto pelo autor, denominado "teoria da fascinação do cinema”. Shaviro e Waugh, em particular, se colocam como referências importantes para nós na medida em que, para além da questão do corpo já presente em

\footnotetext{
${ }^{28}$ É verdade que o projeto de retornar os filmes de Warhol à circulação pelo Whitney Museum datava de 1982, com autorização do próprio Warhol. No entanto, ele só veio à luz após a morte do artista em 1987. Isso é relatado no prefácio de John G. Hanhardt para ANGEL, 1994b, p. 6.
} 
Deluze e Aprà e Ungari, observam as relações do cinema de Warhol com o erotismo e a pornografia, que constituirão um dos polos de nossa discussão neste trabalho.

\section{Nota metodológica: autorismo}

Como já deve estar claro a esta altura, este trabalho se insere numa perspectiva autorista. Isso quer dizer que pretendemos oferecer uma visão de conjunto sobre os filmes de Warhol a partir dos aspectos que mais nos chamam atenção - o que não quer dizer, é claro, que não existam outros pontos de ancoragem possíveis. Em nosso caso, decidimos abordar a obra de Warhol entre dois polos: de um lado, a ideia de um estilo maquínico; de outro, o fato de este ser também um cinema centrado no registro do corpo.

Uma análise autorista da obra de Warhol se vê presa, de saída, num jogo de dissimulação. Embora o artista jamais tenha deixado de assinar suas obras, a incorporação por Warhol de um imaginário maquínico, com a automatização do gesto e o consequente apagamento das marcas de estilo pessoal, torna seus filmes objetos limítrofes, frágeis dentro do cinema. A simplicidade desses filmes faz com que seja muito fácil questionar seu próprio estatuto de "arte". É nesse sentido que uma investigação autorista dos filmes de Warhol pode, em nosso entendimento, ser interessante. Olhar os filmes em conjunto elucida impulsos que passam batidos num Screen Test visto isoladamente. Não se trata, assim, de afirmar que os filmes de Warhol são arte porque "são assinados por alguém", mas de precisar como, por trás de seu caráter aparentemente amorfo, esses filmes podem constituir um conjunto coeso que expressa algo, uma visão pessoal, uma maneira de olhar as coisas.

Boa parte das críticas recentes à abordagem autorista no cinema é centrada no problema do "controle": é possível postular o diretor enquanto autoridade soberana numa prática artística essencialmente coletiva como o cinema, na qual concorrem os esforços criativos de toda uma equipe, atores etc.? Ou ainda: como falar em controle quando o que se imprime no interior da câmera quando se grita "ação" é uma realidade contingente, fugidia, incontrolável por definição? Embora importantes para desmistificar a figura do autor todo-poderoso no cinema, essas objeções não implicam exatamente num questionamento do lugar do diretor como figura central na criação cinematográfica. Sobre o problema, intrínseco ao cinema, de uma realidade que escapa às mãos do diretor, diríamos simplesmente que há diretores mais ou menos inclinados ao controle, e que uma tal postura representa nada mais do que uma escolha estética: aquela entre impor uma 
forma à realidade contingente ou dar a ela maior margem de liberdade. Veremos como Warhol ocupa uma posição peculiar aqui, quando discutirmos a questão do dispositivo em seus filmes. Quanto à participação da equipe, um bom número de análises transversais (muito bem-vindas) tem ressaltado a participação criativa de fotógrafos, atores, entre outros, na elaboração dos filmes. No entanto, a própria noção de obra de arte pressupõe um todo coerente e unitário que concilie suas partes heterogêneas: alcançar essa unidade expressiva no cinema é tradicionalmente tarefa do diretor — é sua obrigação, por assim dizer, já que é ele quem responderá pelo prestígio artístico da obra. Aqui, gostaríamos de lembrar a interessante posição de Jean Renoir, para quem “o autor de um filme é o mais forte", isto é, aquele que, entre os diversos agentes envolvidos na sua produção (ator, diretor, roteirista, produtor), consegue "impor aos outros a linha fundamental" da obra. ${ }^{29}$ Longe de ser assegurada, a posição do diretor como autor de um filme, sua plena expressão individual por meio da obra, passa por um teste de força que é preciso ganhar para ascender à condição propriamente de autor.

Acreditamos que uma boa análise autorista se apoia em dois pontos: 1) profundidade especulativa em relação àquilo que este autor expressa, via seu estilo pessoal, na obra; 2) percepção clara das descontinuidades e paradoxos inerentes ao confronto entre expressão pessoal deste autor e os meios materiais de produção de um filme. Assim, não é suficiente um inventário das marcas de estilo visíveis de um diretor. É preciso buscar também o que ele expressa em termos de uma sensibilidade pessoal, seu olhar sobre o mundo, por assim dizer. No caso de Warhol, o fascinante é observar como o artista, num conjunto tão amplo de filmes, produzidos de maneira tão caótica, foi capaz de imprimir um olhar pessoal (e não simplesmente "mecânico, como tentaremos argumentar no segundo capítulo), dotado de obsessões próprias.

Em nossa análise, gostaríamos de nos aproximar de Peter Wöllen:

Como um sonho, o filme que o espectador vê é, por assim dizer, um filme-fachada, o produto final de uma "revisão secundária", que esconde e mascara o processo que permanece latente no inconsciente do filme. Às vezes a "fachada" é tão trabalhada, tão polida, ou então tão entulhada de elementos díspares, que é impossível enxergar além dela, ou enxergar qualquer coisa além dos personagens, dos diálogos, da história e por aí vai. Mas em outros casos, por um processo de comparação com outros filmes, é possível decifrar não uma mensagem coerente ou uma visão de mundo, mas a estrutura que subjaz e dá forma

\footnotetext{
${ }^{29}$ Cf. Jean Renoir: "Contrato dos diretores" in Escritos sobre cinema, 1926-1971. Rio de Janeiro: Nova Fronteira, 1990.
} 
ao filme, conferindo-lhe um certo padrão de energia catexial. É essa estrutura que a análise autorista libera do filme.

A estrutura é associada com um único diretor, um indivíduo, não porque ele fez o papel do artista, expressando a si ou a sua visão no filme, mas porque é pela força de suas preocupações que um significado inconsciente, não intencional, pode ser decodificado no filme, frequentemente para a surpresa do próprio indivíduo envolvido. $\mathrm{O}$ filme não é uma comunicação, mas um artefato que, num certo sentido, é construído inconscientemente. A análise autorista não consiste em retraçar o caminho do filme em direção à sua origem, à sua fonte criadora. Consiste em traçar a estrutura (não a mensagem) dentro da obra, que pode ser atribuída post factum a um indivíduo, o diretor, a partir de uma base empírica. (WÖLLEN, 1998, pp. 114-15)

Desse pensamento de Wöllen de cunho estruturalista-psicanalítico, gostaríamos de reter seguinte: o filme não é uma mensagem, ele não "comunica" a visão de mundo do autor; ele é um artefato a partir do qual o analista pode remontar a uma sensibilidade pessoal desse autor - que Wöllen chama de "estrutura". Esse ponto de vista é valioso para nós, uma vez que os filmes de Warhol, como aliás sua obra em geral, prezam pela mudez, pela recusa em articular um discurso. Resta disso uma sensibilidade pessoal, o testemunho de uma forma de olhar as coisas, impresso nas imagens, e com o qual iremos lidar.

Em nosso percurso autorista, nosso objetivo é discernir o olhar de Warhol em meio ao jogo de dissimulação proposto pelo artista em sua adesão ao maquínico. Encontrar o homem por trás da máquina - pois aceitar os filmes de Warhol como um mero registro objetivo, maquinal, é comprar de maneira excessivamente fácil o discurso de um artista que sempre fez de tudo para dissimular-se. Partimos da premissa de que assistir a um filme é ver através dos olhos de alguém, um outro.

Ver com outros olhos: essa ideia está intimamente ligada, por sua vez, ao mote comum a uma parcela do cinema experimental, para a qual trata-se justamente de propor uma outra relação perceptiva do espectador com a realidade empírica. Em outras palavras, enxergar a realidade já conhecida, já vista, com outros olhos. É Stan Brakhage quem melhor define essa ideia, cara ao cinema de vanguarda, em seu manifesto Metáforas da visão:

Imagine um olho não governado pelas leis fabricadas da perspectiva, um olho livre dos preconceitos da lógica da composição, um olho que não responde aos nomes a que tudo se dá, mas que deve conhecer cada objeto encontrado através da aventura da percepção. Quantas cores há num gramado para um bebê que engatinha, ainda não consciente do "verde"? (BRAKHAGE, 1983, p. 341) 
Para o cineasta, não se trata, portanto, de imaginar ou construir um outro mundo, mas de perceber a realidade já existente com outros olhos. Ver as coisas de um ângulo inexplorado, que revele uma força oculta ou provoque um estranhamento no já-visto. A realidade em si permanece a mesma: não à toa, a banalidade e o cotidiano permanecem como motivos absolutamente centrais para o cinema de vanguarda.

É o caso de Warhol. Seu cinema se volta justamente para a banalidade, porém propondo um outro tipo de relação perceptiva com essa realidade, que em Warhol passa menos por um ângulo inexplorado do que por uma outra relação com o tempo. Veremos a partir de agora como isso ocorre na prática. 
CAPÍTULO 1

A máquina 


\subsection{Falsa simplicidade}

Procuro sempre a coisa mais fácil, porque, se é a mais

fácil, para mim é geralmente a melhor ${ }^{1}$

Andy Warhol

A primeira impressão deixada pelos filmes de Warhol, e com a qual é preciso se confrontar, é a de sua simplicidade. Realizados de maneira um tanto amadora e desleixada, esses filmes parecem se colocar no limite entre o cinema e o que seria um mero "registro" das pessoas e das coisas. Dominique Païni (1997), curador e pesquisador de cinema, não à toa definirá o cinema de Warhol como "o mais simples aparelho", em referência à sua economia de meios. Uma economia que se estende também ao conteúdo dos filmes: reputados pela fama de que neles "nada acontece", os filmes de Warhol se limitam a registrar pessoas, corpos, gestos ou situações radicalmente isolados, que se esgotam em si mesmos, desconectados de uma narrativa ou de uma relação com o mundo exterior.

Assim, o cinema de Warhol se impõe como um limite: se suas caixas Brillo testavam os limites da arte em geral, seus filmes de muitas maneiras testam os limites do cinema. Neles, trata-se sobretudo de mostrar, de reduzir o cinema a um mero exercício do olhar - e muitos defenderão que em Warhol até mesmo esse olhar está ausente, que sua câmera não passa de um "olho de vidro". São "documentários" cujo tema é a própria presença das coisas diante da câmera, filmes cujo tema frequentemente parece ser o próprio ato de filmar.

Jonas Mekas, como vimos, enxergará nessa simplicidade dos filmes de Warhol um retorno a uma pureza perdida do primeiro cinema, ao território virgem dos irmãos Lumière. Os "ensaios cotidianos" de Warhol (Sleep, Kiss, Eat), em sua literalidade, sua recusa à produção de significados e sua positividade diante do que é oferecido pelo mundo, seriam a expressão de um olhar não codificado, análogo ao das reportagens lumièrianas. Um olhar capaz de nos oferecer as coisas tão puras quanto são "em si mesmas": "o comer enquanto o comer, o dormir enquanto o dormir, o cortar o cabelo enquanto o cortar o cabelo" (MEKAS, 1964, p. 1).

\footnotetext{
${ }^{1}$ WARHOL (2008), p. 99.
} 
A impressão de Mekas em relação a um anseio de retorno, nos filmes de Warhol, a uma pureza perdida do cinema parece ser confirmada por uma anedota. Conta-se que Warhol teria tido a ideia de realizar Kiss, um de seus primeiros filmes, após assistir a um pequeno filme de Thomas Edison, The Kiss, produzido por volta de $1896 .{ }^{2}$ Com efeito, mais até do com os Lumière, talvez seja com os filmes de seu concorrente americano, Edison, que o cinema de Warhol guarda maior proximidade. Realizados em seu estúdio, o Black Maria, os primeiros filmes de Edison tinham como característica marcante a apresentação de pequenos "números" (uma dança, uma acrobacia, um beijo) isolados sob um fundo escuro. Esse isolamento da figura e da cena será também central em Warhol, como veremos. Seus filmes, em sua imensa maioria, se passam em internas, e mesmo quando se voltam para o tema, lumièriano por excelência, do cotidiano, trata-se de um cotidiano apartado do mundo, examinado em seu laboratório particular: via de regra, no espaço da Factory.
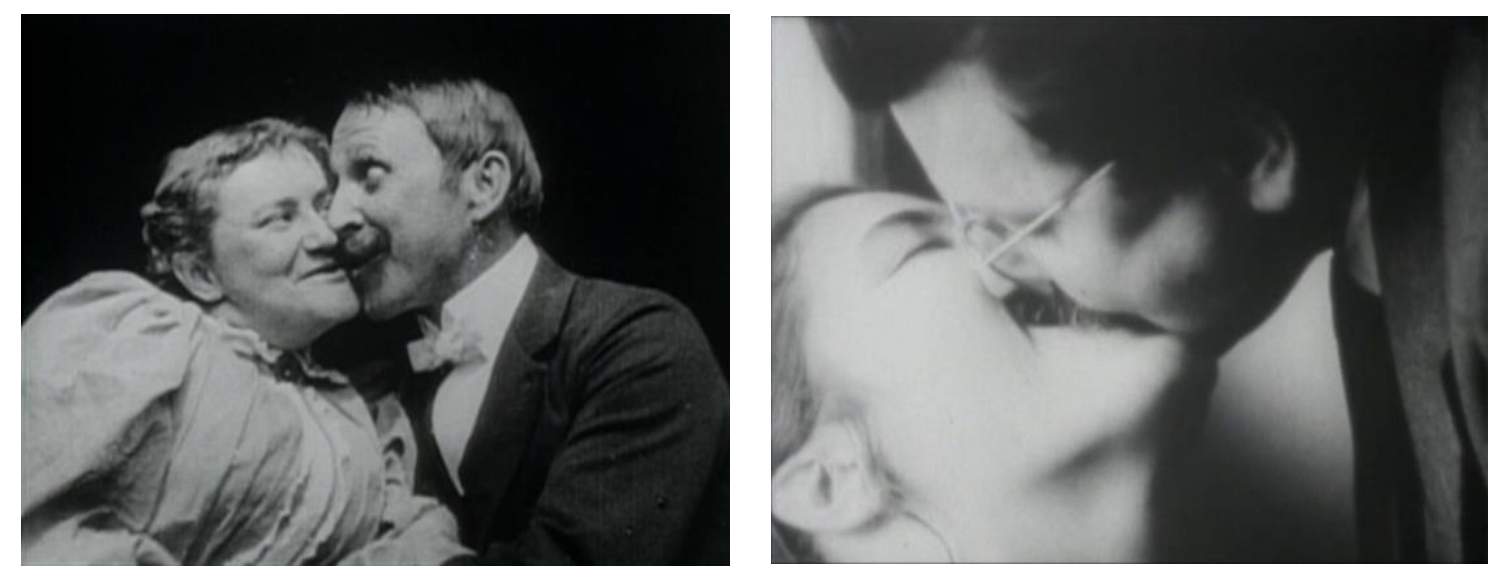

À esquerda, uma das versões de The Kiss feita por Thomas Edison em 1896. À direita Kiss (1963-64), de Warhol

No entanto, se há de fato um anseio de retorno a uma pureza originária do cinema em Warhol, é preciso que se diga este é um retorno consciente de seu tempo. Já mencionamos que o sonho retornar às coisas mesmas, de transcender o código, é um mito vanguardista que muito frequentemente animou os cineastas, numa tradição que vai do construtivismo de Vertov ao próprio Mekas. ${ }^{3}$ A questão que se coloca aqui é: como ser Lumière, ou

\footnotetext{
${ }^{2}$ A anedota é relatada em RAYNS (1989, p. 164) e BOCKRIS (2003, p. 512)

${ }^{3}$ É Jacques Rancière (2012) um dos que melhor sintetiza o projeto vertoviano de levar o olho às coisas: "O que a câmera de Dziga Vertov suprime é aquela demora ou o intervalo que dá ao olhar a possibilidade de
} 
Edison, nos anos 1960? Como reconduzir o olhar do espectador (já saturado de códigos) a uma relação puramente física, denotativa e sensorial com as imagens? Como fazê-lo tão somente ver as coisas, tão puras quanto são "em si mesmas"? "O comer enquanto comer, o dormir enquanto dormir, o cortar o cabelo enquanto cortar o cabelo." Como retornar a esse território virgem, a essa relação inocente com as imagens? Em 1963, como também agora, só é possível "retornar a Lumière" com a ajuda de alguns dispositivos bastante complicados, e é por isso que é preciso olhar o cinema de Warhol para além de sua simplicidade e de sua banalidade aparentes.

Veremos neste capítulo que esse retorno a um olhar "puro" em Warhol é, na realidade, mediado por um ambicioso projeto: aquele de tornar-se máquina. É o estilo maquínico, frio e impessoal que Warhol traz consigo da pintura para o cinema que, como uma máscara, permite ao artista dissimular-se e almejar este "grau zero" em que as coisas apenas são o que são. Em outras palavras, é preciso tornar-se máquina, ser absorvido por ela, para registrar as coisas "tão puras quanto são em si mesmas". E, na medida em que se trata de um processo de dissimulação, essa máscara maquínica da indiferença precisa ser ostensivamente ressaltada, de muitas formas. Veremos algumas delas nas páginas que se seguem.

Ao longo deste capítulo, examinaremos as origens e alguns problemas teóricos envolvendo este projeto maquínico de Warhol. Antes, no entanto, traçaremos um breve percurso pela produção fílmica de Warhol como um todo. Propomos aqui uma divisão em fases: a primeira compreendendo os filmes silenciosos, incluindo aí seus trabalhos mais conhecidos, como Kiss, Eat, Sleep e Empire; a segunda os primeiros filmes sonoros, cuja encenação é montada numa espécie de cubo/palco; e a terceira os chamados filmes de sexplotation, que explicitam uma tensão presente no cinema de Warhol como um todo Com esse percurso, pretendemos mostrar que a obra de Warhol no cinema é mais complexa, e mais rica, do que a invisibilidade que por anos deu a tônica dos comentários sobre seus filmes pode sugerir.

colocar uma história em um rosto" (p. 41). Essa história, ou narrativa, é a prestidigitação por meio da qual o cinema de ficção tradicionalmente manipula as aparências. Essa falsidade é recusada pelo cine-olho, cuja objetividade consiste em fazer equivaler todos os movimentos: "o automatismo do olho máquina dissolve tanto o imperialismo do olhar quanto suas sujeições [...] a verdade da máquina de movimento é a igualdade de todos os movimentos" (pp. 42-43). 


\subsection{Fases e gêneros}

1) Filmes silenciosos

Dizíamos então que é possível distinguir três fases na produção fílmica de Warhol. A primeira compreende os filmes silenciosos, realizados em sua maior parte entre $1963 \mathrm{e}$ 1964: Kiss, Sleep, Eat, Haircut, Empire, Blow Job, toda a produção de Screen Tests silenciosos, entre outros. Nesses filmes, Warhol põe em prática um projeto relativamente simples: isolar e registrar corpos/gestos cotidianos. É a fase mais conhecida de sua filmografia, que responde pelo senso comum que se costuma ter de seus filmes: sabe-se que são filmes em que "nada acontece", registros da "banalidade" e do "cotidiano". A fama conquistada por essa parte da produção responde também pela maior parte dos equívocos difundidos sobre a obra cinematográfica de Warhol, como o de se tratariam de meras peças conceituais que, a rigor, sequer precisariam ser vistos ou de que são filmes "sobre o tempo", que nos colocam em contato com um "tempo real" puro.

Nesses primeiros filmes, a câmera normalmente isola um corpo que realiza um gesto banal. Esse corpo em geral é seccionado: na maioria das vezes, a câmera é atraída pelos rostos em close ups (Eat, Kiss, Blow Job, os Screen Tests), mas pertencem igualmente a essa época filmes como Shoulder (1964), em que Warhol filma o ombro da coreógrafa Lucinda Child, e Taylor Mead's Ass, que registra a bunda do ator Taylor Mead, sem falar da variedade de pontos de vista sobre o corpo em Sleep. Esses corpos eram registrados quase sempre sem cortes em rolos de aproximadamente 2 minutos e 45 segundos de duração, que Warhol, via de regra, deixava rodar até o fim, incluindo pontas. Em alguns casos, o registro se estendia por vários rolos sem mudança de enquadramento (as oito horas de Empire, os 40 minutos de Eat), enquanto em outros, como os Screen Tests, a filmagem de um rolo correspondia ao filme acabado. Nem todos os filmes, porém, eram absolutamente estáticos: em Sleep e Haircut, por exemplo, há variações de ponto de vista sobre a cena (Sleep, o suposto filme de um homem dormindo "em tempo real", na realidade possui um considerável trabalho de montagem, com Warhol tendo filmado bem menos material do que as 5 horas finais e repetindo tomadas em loop). Por fim, o mais importante: todos os filmes dessa fase silenciosa eram projetados a 16 fotogramas por segundo, portanto, numa velocidade mais lenta do que os 24 fotogramas por segundo habituais. 


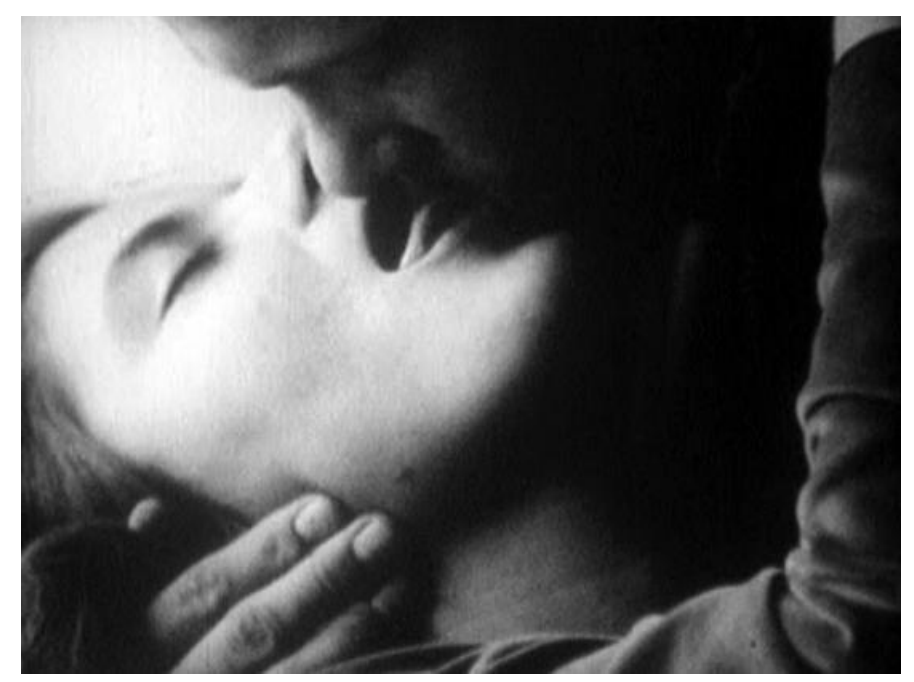

Kiss (1963-64)

A ausência de som, a ralentação e o retalhamento do corpo fazem desses filmes uma experiência muito particular e distinta dos filmes posteriores de Warhol, quando o corpo retoma sua integralidade e seu poder da fala. A projeção a 16 fotogramas por segundo cria o que Stephen Koch (2002, p. 39) chama de um "tempo literal alucinado": as lentas repetições dos gestos (comer, beijar, respirar) nos colocam numa espécie de transe. Ficamos presos numa estrutura espaço-tempo em forma de espiral, composta por movimentos circulares que sempre retornam ao mesmo lugar (contração-descontração da respiração, circularidade da boca que beija ou mastiga). Daí a sensação, comentada por Pamela Lee (2004), de que os filmes de Warhol nos atiram num "presente perpétuo" (pp. 278-288). Tudo isso acaba por provocar um estranhamento em relação a esses corpos cotidianos e banais. O cotidiano é isolado como num laboratório e observado sob um olhar clínico, a uma velocidade mais lenta, revelando tessituras não observáveis no dia a dia.

Essa fase silenciosa costuma ser mais associada, não sem razão, ao trabalho de Warhol como artista plástico. A mudez desses filmes é análoga àquela das latas de sopa Campbell: são corpos que se limitam a estar ali, auto-evidentes, ao mesmo tempo absolutamente expostos e absolutamente misteriosos. O caráter estático desses filmes sem dúvida também contribuiu para a tendência de lê-los como simples telas pintadas acrescidas da dimensão do tempo: assim, críticos como Dominique Païni (1997) ressaltarão as "virtudes plásticas da imagem" (p. 91), entrevendo olho de pintor no Warhol cineasta. Numa outra via, há também uma tendência, igualmente derivada do intercâmbio com as artes plásticas, de se ler esses filmes num plano excessivamente 
conceitual. Nesse sentido, alguns enfatizam a serialidade: uma vez que Warhol renuncia ao poder do "corte", o filme se torna apenas um sequenciamento dos rolos: um rolo após o outro, após o outro, após o outro. ${ }^{4}$ Outros se concentram no suposto caráter autorreflexivo desses filmes: o filme se torna meditação sobre o tempo ou sobre o próprio ato de ver um filme.

Embora compreensíveis, essas leituras muitas vezes se pautam por um olhar excessivamente exterior às obras, negligenciando ir ver o que há efetivamente no interior desses filmes: o olhar do cineasta sobre aquilo que filma. É justamente esse olhar que atravessa a obra filmica de Warhol como um todo e faz dela uma expressão coerente em termos especificamente cinematográficos. Não raro, críticos inclinados a ler os filmes de Warhol como uma continuidade de suas telas se focarão apenas nesta primeira fase da produção, rejeitando o resto como uma concessão ao cinema narrativo, comercial ou, pior, pornográfico. Para nós, no entanto, os diversos filmes de Warhol se comunicam mais do que sua aparência pode sugerir: a forma dos filmes certamente muda, mas a visão do cineasta sobre aquilo que filma, suas obsessões vitais, permanece as mesmas. É nesse ponto que uma abordagem autorista pode ser valorosa: pois não gostaríamos de nos limitar a ver nos filmes o que nos interessa, mas atentar também para aquilo que interessa aos próprios filmes e seu autor - em outras palavras, ver com os olhos de outro.

\section{2) Cubo e palco}

A segunda fase compreende os primeiros filmes sonoros e tem como marca a criação de um espaço cênico rígido, concebido à maneira de um cubo ou palco. Fazem parte dessa época os filmes Vinyl, Beauty \#2 (1965), Chelsea Girls, Kitchen, Poor Little Rich Girl (1965), The Life of Juanita Castro, Screen Test \#1 (1965), entre outros. Talvez seja a fase mais eclipsada da carreira cinematográfica de Warhol, mas também na qual se encontram alguns de seus melhores filmes. É significativa nesse período a parceria com o dramaturgo Ronald Tavel, que se tornaria mais conhecido pelo movimento nova-iorquino "teatro do ridículo", cujas ideias parecem se frutificar já nesses primeiros trabalhos com Warhol. Os dois se conheceram no fim de 1964, quando Warhol acabara de adquirir sua primeira câmera com som sincronizado, uma Auricon que lhe permitiria também usar rolos de maiores, de 1200 pés (cerca de 33 minutos de duração a 24 fotogramas por segundo). $O$

\footnotetext{
${ }^{4}$ Segundo Peter Gidal (1991, p. 80) os rolos que compõem Kiss inicialmente seriam reunidos sob o título de Andy Warhol Serial.
} 
primeiro filme sonoro rodado é Harlot (1964). Filmado com a câmera sempre fixa, o que se tornaria um dos traços marcantes dessa fase, o filme estabelece uma composição tipo tableau com Mario Montez, Carol Koshinskie, Gerard Malanga e Philip Fagan sobre um sofá enquanto todo o som vem de conversas fora de campo. Aqui, Warhol já lança mão de um procedimento sonoro que reapareceria em outros filmes, fundado na separação entre detentores da palavra e detentores do corpo, o que se torna nítido em filmes como My Hustler (1965) e Screen Test \#1 (1965) e que comentaremos melhor no segundo capítulo.

Os filmes dessa fase possuem um claro diálogo com o teatro, fruto, sem dúvida, da influência de Tavel. Mas esse "teatro" nos interessa apenas na medida em que é transformado em algo especificamente cinematográfico: na criação de um espaço cênico fixo e anterior ao próprio filme e/ou à cena em si. Essa fixidez e esse caráter a priori do espaço se estende também ao próprio tempo: pois não é a cena em si mesma que determina a duração aqui, pois a duração também é um dado a priori: o tempo de um ou mais rolos de cerca de 33 minutos. Assim, Warhol constrói aqui aquele que é provavelmente o dispositivo mais vital de sua carreira como cineasta, em que os corpos e performances são aprisionados num espaço-tempo a priori que os exaure, fazendo-os passar por um contínuo processo de construção e desconstrução. Esse “dispositivo de tortura" é também a base funcional de todos os Screen Tests (dos silenciosos inclusive). A câmera revela uma beleza e uma verdade do corpo (a tal da "fotogenia"), mas a que preço?

Quase todos os Warhol eram rodados em internas, e isso é importante. Há, claro, exceções, como Empire (filmado de um terraço), a primeira metade de My Hustler, bem como alguns filmes inacabados. ${ }^{5}$ Mas a filmagem em interna era a regra, o que possui grande influência na sensação de confinamento e de náusea provocada pelos filmes. Se podemos falar numa influência teatral nesta época, portanto, ela deve ser entendida como algo rapidamente assimilado por um projeto maior. Assim, o dispositivo-cubo talvez tenha sua matriz no palco, mas ele prossegue numa série de projetos posteriores rodados sem Tavel: Chelsea Girls, Beauty \#2, Poor Little Rich Girl, entre outros. Em Chelsea Girls, cada cubo de espaço-tempo parece corresponder conceitualmente a um dos quartos

\footnotetext{
${ }^{5}$ Entre os inacabados, Warhol relata por exemplo ter filmado o bailarino Freddy Herko andando de patins pelas ruas numa ideia intitulada Roller Skate. Reforçamos aqui que não contamos os filmes dirigidos por Paul Morrissey, como Flesh, Trash e Heat, que fogem ao nosso corpus. O fato de que esses filmes são em grande parte rodados em externa responde em parte, aliás, embora não totalmente, ao motivo de eles não provocarem a mesma náusea e a mesma lassidão que sentimos nos filmes dirigidos por Warhol.
} 
do Hotel Chelsea, estrutura esta que é reforçada pela dupla projeção, que dá a entender a apresentação de duas situações em "cômodos" adjacentes. O que interessa reter, portanto, da ideia de palco é a criação de uma área interna isolada com uma câmera posicionada de maneira fixa: é criado, assim, um espaço “ideal”, uma área limpa e laboratorizada, onde os corpos são dispostos e devem performar, submetidos ao escrutínio da câmera. Uma câmera que pode ora permanecer fixa e impassível, ora passear pelos corpos e rostos por meio de zooms, portanto sem sair do lugar, sem comprometer o espaço instituído a priori.

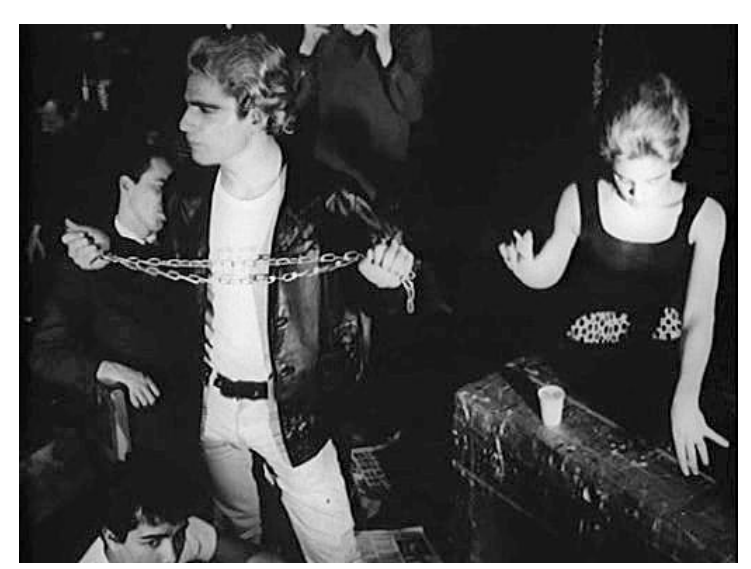

Vinyl (1965)

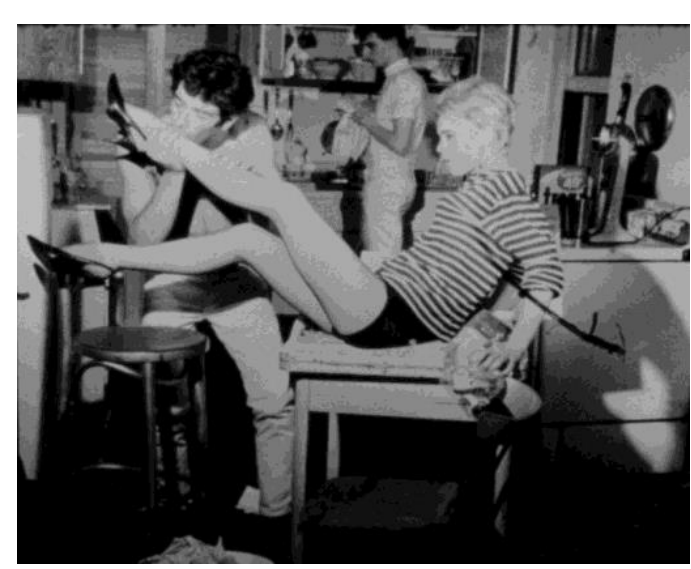

Kitchen (1965)

\section{3) Arquétipos e sexplotation}

A terceira fase é aquela normalmente associada ao gênero do sexplotation, expressão usada para designar filmes com conteúdo erótico anteriores à disseminação da pornografia. Pertencem a essa época I, a Man (1967), Lonesome Cowboys (1967-68), Bike Boy (1967-68), The Nude Restaurant (1967), Blue Movie e San Diego Surf (1968). Os filmes aqui passam a ter alguma montagem e, em alguns casos, a esboçar alguma narrativa (Lonesome Cowboys). A montagem na maior parte das vezes era feita diretamente na câmera, com os chamados strobe cuts. A câmera $16 \mathrm{~mm}$ criava flashes na imagem toda vez que o obturador fechava e abria, marcando a passagem entre os takes. Esses flashes são incorporados por Warhol à fatura dos filmes, dando a entender que, mesmo havendo cortes, o resultado final do filme correspondia rigorosamente à ordem em que os planos foram rodados. Ainda que isso nem sempre fosse verdade: Lonesome Cowboys passou por um processo de montagem. Mais do que qualquer outra coisa, esses 
flashes nos cortes se tornariam uma marca estilística dos filmes de Warhol — sendo inclusive incorporados por Paul Morrissey em Flesh.

Esta "fase" se inicia após Chelsea Girls, que seria o filme comercialmente mais rentável de Warhol e que marca um ponto de virada em sua produção fílmica. Lançado em setembro de 1966, logo após as apresentações do Exploding Plastic Inevitable com o Velvet Underground, o filme causou alguma excitação, sobretudo por apresentar pessoas explicitamente drogadas ("uma imagem da total degeneração da sociedade americana", como propagandeou na época o jornal underground $E V O$ ), conseguindo extrapolar o circuito underground usual e ganhar exibições em outros cinemas em Nova York. Até então, os filmes de Warhol eram exibidos apenas para pequenas plateias específicas e haviam dado rigorosamente nenhum retorno, com exceção de My Hustler, que após a estreia na Filmmakers' Coop ganhara uma sobrevida no Hudson Theatre, seguindo a onda de sessões noturnas de filmes de sexplotation em cinemas nova-iorquinos na década de 1960 (MURPHY, 2012, pp. 191-192; BOCKRIS, 2003, p. 539). Segundo Victor Bockris (2003), Chelsea Girls rendeu a Warhol cerca de US\$ 300 mil (metade da renda da bilheteria), além de notoriedade nos jornais e alguns processos. Desde o ano anterior, 1965, a faceta de "artista comercial" de Warhol ganhava cada vez mais espaço. Com o agenciamento do Velvet e a ascensão de Paul Morrissey na Factory como uma espécie de gerente e assistente pessoal de Warhol, os filmes passaram a se orientar cada vez mais para o nicho em potencial do sexplotation.

O nome "Paul Morrissey" sempre provoca certa confusão quando o assunto são os filmes de Warhol. O teor abertamente sexual dos filmes de Warhol da fase 1967-68 e a própria parceria com Morrissey nesse momento faz com que esses filmes sejam frequentemente colocados no mesmo balaio de Flesh (1968), Trash (1970 e Heat (1972), a trilogia dirigida por Morrissey e produzida por Warhol. Embora haja pontos de contato entre os últimos filmes de Warhol e a trilogia de Morrissey, há igualmente diferenças claras de temperamento e teor. Não se trata apenas de uma questão de assinatura: o discernimento da sensibilidade de Warhol como diretor de cinema não apenas impõe, como torna natural e evidente a distinção entre seus últimos filmes e aqueles totalmente controlados por Morrissey.

De maneira geral, os filmes dessa época são centrados na construçãodesconstrução de arquétipos masculinos tais como o cowboy (Lonesome Cowboys), o biker (Bike Boy) e o surfista (San Diego Surf). I, a Man, o primeiro desses filmes, trabalha com esse jogo arquetípico de forma menos icônica e mais elementar: Tom Baker encarna 
uma masculinidade neutra, comum, que entra em contado com uma variedade de estereótipos femininos, como a adolescente que vive com os pais (Cynthia May); a garota de programa (Stephanie Graves — "tenho muitos amigos", ela diz para explicar seu apartamento); a lésbica (Valerie Solanas); a mulher casada (Bettina Coffin). Episódico, o filme estabelece a estrutura circular que será a marca dos filmes desse período. Assim, diferentemente da fase anterior, centrada no confinamento do cubo cênico, aqui as cenas (e os cenários) se multiplicam, mas jamais se conectam numa narrativa linear que avança,

No interior das cenas, a estagnação, a fadiga e a exaustão seguem consumindo os corpos. Diferentemente da estética softporn, o sexo aqui não é exatamente "encenado": o que vemos são antes tentativas, ensaios, esboços laterais de algo que nunca chega a se consumar. O sexo é sempre algo já passado ou em vias de acontecer — mas que não se concretizará. Enquanto isso, os arquétipos vão sendo dissolvidos na experiência de um corpo que tagarela, ensaia uma série de poses provisórias, se enfastia (veremos melhor como esse processo se dá no segundo capítulo).

Os filmes dirigidos por Paul Morrissey irão retomar a maior parte das marcas estilísticas do cinema de Warhol: os strobe cuts, a circularidade episódica, o humor camp, o homoerotismo declarado. No entanto, em Morrissey esses elementos são submetidos a uma economia narrativa mais eficaz: há significativamente mais cortes do que em Warhol, e se um filme como Flesh pode, como afirma Deleuze (2005, p. 230), contemplar o "tempo de espera" do "prostituto", é apenas enquanto tema: muito diferentemente do tempo desértico dos filmes de Warhol, o tempo aqui é recheado por uma série de acontecimentos (Joe D'Alessandro lê um jornal, anda, joga conversa fora: ele nunca para). Mesmo no plano-sequência que abre o filme a duração prolongada é atenuada pela canção jazzística Makin’ Wicky Wacky Down in Waikiki.

Mais do que isso, a circularidade de Flesh opera em torno de um conceito: os diferentes usos do corpo, ou da "carne": prostituição, modelo/muso, academia de ginástica, cirurgia plástica, todos esses temas ressurgem nos diálogos do filme, numa clareza conceitual que quase não se vê nos filmes de Warhol. Também o corpo excessivamente esculpido de Joe D'Alessandro representa uma mudança em relação aos superstars de Warhol, escolhidos mais por seu carisma, desinibição e espontaneidade do que por um ideal de beleza pronto para o consumo - basta lembrar da flacidez dos corpos de alguns atores recorrentes em Warhol, mesmo nesta última fase, como Viva, Taylor Mead e Ondine. O que diferencia os filmes de Morrissey dos de Warhol, em suma, é a própria concepção de sexualidade e como isso se manifesta no olhar dos filmes. Morrissey 
nos oferece relances dos corpos enquanto os insere numa estrutura conceitual maior; Warhol trabalha desmontando toda estrutura num puro exercício de observação para esses corpos.

Desmontar a estrutura: pois nos filmes dessa época, como dizíamos no início, trata-se justamente de desconstruir arquétipos. Em Lonesome Cowboys, Warhol e Morrissey queriam filmar o que "acreditavam que havia sido deixado de fora da maior parte dos westerns, isto é, a atração sexual [...], a camaradagem gay que existia entre os cowboys" (MURPHY, 2012, p. 214). Assim, no início do filme, Joe D’Alessandro e Eric Emerson, vestidos a caráter, conversam sobre as roupas e cortes de cabelo um do outro, denotando justamente a abordagem fetichista da iconografia do western.

Lonesome Cowboys talvez seja o filme desse período que melhor explicita, em sua própria fatura, a tensão entre os projetos antagônicos de Warhol e Morrissey. Filmado não em Nova York, mas em Tucson, no Arizona, é um dos raros filmes assinados por Warhol ambientados em paisagens externas e que chega a esboçar algum desenvolvimento narrativo. Há uma situação global: um grupo de cowboys aterroriza a dona de uma propriedade no "velho oeste". E um desfecho: os dois vaqueiros decidem partir juntos para a Califórnia em direção ao mar, abandonando o grupo. O filme apresenta mais ação e um trabalho de montagem mais incisivo do que outros filmes Warhol. Tudo isso pode ser colocado na conta de Morrissey, que antes da viagem também escreveu um argumento de "duas páginas que tentava desenvolver história e personagens" (ibid.). Ainda assim, o olhar da câmera aqui é todo de Warhol: é flagrante em diversos momentos o desdém da câmera pelo conteúdo das falas, a pouca funcionalidade da decupagem, com zooms e cortes que passeiam por rostos e outras partes dos corpos na cena. Apesar do esboço de "estrutura", o resultado é pouco consistente: os personagens e a história estão sempre em vias de se desconstruir em performances digressivas ora de tom jocoso, ora bastante violentas. Como relata David Bourdon:

Andy estava na câmera filmando como de hábito, fazendo todos os zooms malucos e perdendo toda ação, e Fred [Hughes] segurava o microfone, mas ao lado havia sempre Paul [Morrissey] dizendo "agora faça isto, agora aquilo, está acima do tom." Vários atores contestaram e acho que eles tinham alguma razão. Paul tinha a mão muito pesada e não os deixava improvisar livremente. (BOCRKIS, 2003, p. 606) 
É importante entender que as três fases de Warhol não são estanques. Entre os primeiros filmes rodados por Warhol, por exemplo, estavam os inacabados Tarzan e Jane Regained... Sort of (1963), filmado numa viagem a Los Angeles, e Batman Dracula (1964), com Jack Smith no papel principal, em que o diálogo explícito com o gênero e com a iconografia pop os coloca mais em sintonia com os filmes da fase final. Warhol também rodará Screen Tests silenciosos durante alguns anos. Os Screen Tests, aliás, podem ser imaginados tanto como estudos silenciosos ("primeira fase") quanto como cubos que isolam e aprisionam seus personagens, torturando-os ("segunda fase"). Há igualmente filmes que não se encaixam em nenhuma das fases, como Soap Opera (1964), que mantém um diálogo muito vivo com a arte pop e que precisaria ser analisado à parte.

Mais do que uma divisão cronológica, essas fases representam três figuras ou etapas que se encadeiam na construção do dispositivo-Warhol: 1) isolamento da figura para seu estudo; 2) ampliação deste espaço laboratorial e incorporação do som para que a figura seja estudada em seu todo, enquanto fala e se expressa; 3) dissolução de arquétipos e papeis sociais e narrativos numa pura experiência corpórea. Essa dissolução da imagem-como-representação numa pura experiência física do corpo já se encontrava nos primeiros filmes: acreditávamos, por exemplo, que estes eram filmes "sobre o sono" ou "sobre comer", mas essas ações, expostas ao tempo prolongado, eventualmente se dissociavam da função que as motivava (comer, dormir) e se dissolviam numa pura experiência voyeurista de olhar o outro. Contrariamente à tendência de se separar os filmes de Warhol em função da presença de outros colaboradores (Tavel, Chuck Wein, Paul Morrissey e suas diversas vedetes), nosso objetivo aqui é buscar justamente o que une esses filmes, o que permanece constante na obra fílmica de Warhol: em particular, o apego pelo corpo, que será o tema do segundo capítulo.

\section{Filmes-retratos}

Nenhum gênero predomina mais na carreira de Warhol do que o filme-retrato. Aqui rapidamente pensamos nas centenas de Screen Tests silenciosos realizados entre 1964 e 1966, ou mesmo em suas duas versões sonoras, Screen Test \#1 e Screen Test \#2 (1965). Mas os Screen Tests são apenas a manifestação mais literal de uma ideia que se encontra difusa na obra fílmica de Warhol como um todo. Como afirma Callie Angell, "praticamente todos os filmes de Warhol têm como preocupação o ato de retratar" (1994a, 
p. 2). A preocupação em retratar não se restringe aqui a um sentido formal. Em termos mais amplos, os filmes de Warhol se estruturam em função de seus atores: eles são veículos para suas vedetes, que se abrem a elas e desejam nos apresentá-las.

$\mathrm{Na}$ pintura, o retrato é um quadro que se organiza em torno de um indivíduo, procurando apresentá-lo. Apesar de ser uma representação exterior desse indivíduo, ele deve, no melhor dos casos, exprimir sua personalidade, um "eu interior", embora atendose à exterioridade. Por ser voltado para a apresentação da personalidade do indivíduo, uma das principais características do retrato é a ausência de ação. Como afirma Luiz Carlos Oliveira Jr., o retrato “deve não somente prescindir da ação como até mesmo evitála" com o objetivo de "não desviar a atenção do espectador da personalidade e deslocála para a narrativa" (2016, p. 3). É nesse sentido que o retrato possui também uma relação com o perene: ele visa à expressão de um “eu” estável em contraposição ao fluxo volúvel do mundo.

A prática retratista de Warhol passa, em primeiro lugar, por um isolamento espacial do corpo, via de regra em ambientes internos. Em seguida, esse corpo é privado também da ação: ele deve permanecer ali, apenas sendo "ele mesmo". Warhol reduz a ação em seus filmes à banalidade para que aflore a personalidade, ou a persona, a máscara performativa do indivíduo. Veremos no segundo capítulo as consequências desse jogo entre o "eu" e a construção de uma performance. Por ora, gostaríamos apenas de reforçar a evidência óbvia de que os filmes de Warhol se interessam não em instituir uma ação, mas em registrar os atores-modelos.

De sua versão mais elementar nos Screen Tests silenciosos, o retratismo em Warhol pode assumir formas mais complexas. A começar pelos "testes" sonoros, Screen Test \#1 e Screen Test \#2, em que a câmera filma as expressões respectivamente de Philip Fagan e Mario Montez enquanto estes são provocados por vozes fora-de-campo. Filmes como Poor Little Rich Girl e Chelsea Girls podem igualmente ser pensados como retratos de suas vedetes, uma vez que se esgotam na performance de seus personagens: o interesse deles reside na atenção à performance, à expressão e ao gestual dos atores, sem se prolongarem numa narrativa. Cria-se assim uma afirmação tautológica da presença física das vedetes.

Poor Little Rich Girl, composto por dois rolos de cerca de meia-hora (o primeiro deles inteiramente fora de foco), se pretende uma espécie de "um dia na vida" de Edie Sedgwick. Edie aqui "interpreta" a si mesma (num trecho ao telefone, identifica-se como "Edie Sedgwick"). O filme se passa todo num quarto, em um mesmo espaço de poucos 
metros, que a câmera estabelece desde o início e que se limita a explorar com zooms. Começa com Edie dormindo. Ela acorda, dá telefonemas, pede café e "cinco sucos de laranja", dando a entender que vive num hotel (o que é natural devido à origem aristocrática de Edie, sugerida no título do filme), exercita-se, canta, dança, se maquia. Eventualmente, discute com Chuck Wein, seu "companheiro", que permanece sempre fora de quadro. As ações se fecham em si mesmas: elas existem apenas para construir um repertório de gestos e rituais que constitui o universo "Edie Sedgwick". A ideia de retrato surge tanto pelo fato de o "tema" do filme ser a própria Edie Sedgwick (seus gestos, rituais, seu espaço), quanto pela presença física continuamente reiterada de Edie (ela jamais sai de quadro), que, sem roteiro pré-estabelecido, se limita a projetar sua própria presença.

Bike Boy também pode ser considerado um filme-retrato à sua maneira: mais ficcional do que documental. Joe Spencer é um biker, um motociclista rebelde no melhor estilo do imaginário criado por Marlon Brando em O selvagem (László Benedek, 1953). ${ }^{7}$ No entanto, não há ação aqui. Sequer vemos Spencer sobre uma moto: todas as cenas se passam em internas, em pequenas conversas com outros personagens, numa estrutura circular semelhante à de $I$, a Man. Estruturalmente, o personagem ocupa o centro desse círculo, e é por isso que o filme pode ser pensado como um retrato. A começar pela cena inicial, que mostra por mais de dez minutos Spencer tomando banho nu, ensaboando-se, enxugando-se, vestindo-se, eventualmente olhando para fora de quadro como se recebesse instruções em off: o retrato aqui é perversamente objetificador, e esta será a tônica do filme como um todo. Vemos Spencer experimentando roupas numa loja (fetiche da roupa), posando masculamente numa cozinha enquanto a seu lado Ingrid, uma das superstars de Warhol, faz um monólogo sobre legumes (relação arquetípica maridomulher, mulher faladeira-homem taciturno, queen e hustler, como veremos mais adiante), bancando o garoto de programa com uma mulher mais velha (prostituição: fetiche do corpo) ou em interações mais livres e improvisadas com outras mulheres, mas nas quais os corpos (por exemplo, as tatuagens de Spencer) são sempre o assunto. Essa circularidade do corpo prefigura Flesh, de Morrissey, mas não há desenvolvimento (Flesh possui uma diegese e uma narrativa muito mais consistentes). Bike Boy está mais para um

\footnotetext{
${ }^{7}$ As gangues de motociclistas eram uma figura presente no imaginário jovem dos Estados Unidos nos anos 1950 e 60. Antes de Warhol, Kenneth Anger havia feito igualmente uma homenagem fetichista à figura do biker em Scorpio Rising (1964).
} 
ensaio fotográfico em movimento, um calendário erótico em que o corpo ostenta os nossos desejos e fetiches.
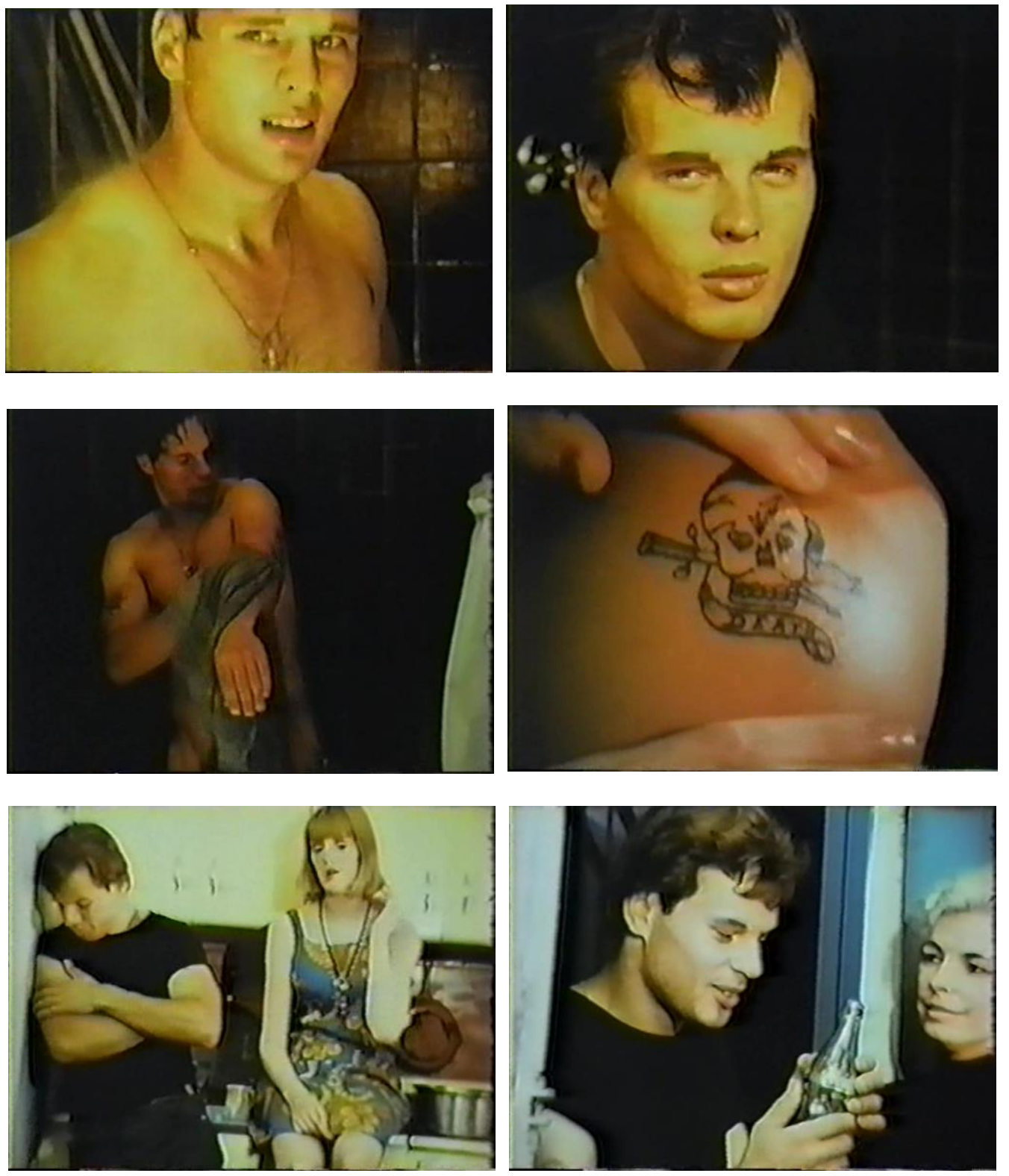

Bike Boy (1967) 


\subsection{A máquina}

Dizíamos mais acima que a característica que mais imediatamente salta aos olhos nos filmes Warhol é sua simplicidade. Mas seria preciso caracterizar melhor essa simplicidade. Ela não é a mesma simplicidade dos filmes-diários de Jonas Mekas, por exemplo. Dizer que os filmes são "simples" é dizer ainda muito pouco, é ser pouco específico. A simplicidade em Warhol está estreitamente ligada a uma outra ideia: a banalidade. Essa banalidade é temática nos primeiros filmes, os "ensaios cotidianos", como Eat, Kiss, Sleep, Drink e Haircut. Mas ela é também, e sobretudo, estética, se revelando na monotonia, na insipidez, na ausência de articulações visíveis desses filmes, que anseiam apenas registrar as coisas "mais simples da maneira mais simples possível" (MEKAS, 1964).

No fundo, a ideia de banalidade aplicada aos filmes de Warhol sugere que há um vácuo no interior deles. "Simplicidade" e "banalidade" se endereçam à superfície das obras, enquanto falar de uma vacuidade já remete a algo além, mais profundo, mesmo que essa profundidade seja negativa. Sobretudo porque é bastante evidente que a vacuidade em Warhol não é resultado da mera afasia: ela é um projeto. Seu projeto. Steven Shaviro nota muito bem que a sensação de vazio e superficialidade que emanam das obras de Warhol são efeitos construídos:

É muito difícil "fazer com que nada aconteça": isso requer muito trabalho, mesmo que parte da realização de Warhol seja a de nos dar a sensação de que "nada" é fácil e óbvio. A banalidade e a autoevidência das superfícies de Warhol parecem ser a própria simplicidade, mas esse vazio e essa "semelhança alucinatória" são um "look" que precisa ser cuidadosa e deliberadamente produzido. (SHAVIRO, 2015, p. 238)

Em outras palavras, como construir a vacuidade? Pela via do maquínico. É ar maquínico, presente na obra de Warhol como um todo, desde as pinturas e serigrafias até os filmes, as polaroides, os gravadores, a televisão, que cria a sensação de vacuidade. O artista é absorvido pela máquina: desde as latas de sopa Campbell, ele se esforçava para não deixar nenhum traço pessoal. Só que as imagens de Warhol carregam, em si mesmas, o rastro dessa absorção. Elas não são apenas "impessoais", de uma indiferença afásica. São maquinicamente impessoais, possuem um gosto inorgânico, o gosto do vácuo resultante 
da absorção do artista pela máquina. A partir de agora iremos destrinchar melhor esse "estilo maquínico", essa intrincada relação da obra de Warhol com a ideia da máquina.

Tudo começa nas pinturas. Embora já se dedicasse a copiar anúncios publicitários e tirinhas há algum tempo, o ano de 1961 marca uma guinada no traço de Warhol como pintor. Até então, a maior parte de suas reproduções tinha como característica a presença de rabiscos e marcas aparentemente involuntárias de pintura, gotejamentos (drips, em inglês) de tinta sobre a superfície chapada do anúncio ou cartum. Foi Ivan Karp, então agente da galeria Lou Castelli, quem parece ter primeiro aconselhado Warhol a evitar as marcas de tinta: “Talvez seja possível fazer, já que Roy Lichtenstein está fazendo sem gotejar. Talvez você consiga fazer uma pintura moderna sem gotejar". 8 Alguns meses depois, Warhol apresentaria a Emile De Antonio duas versões de uma garrafa de CocaCola: a primeira repleta de marcas e borrões de tinta, a segunda com um traço liso, ainda mais definido e mais gélido do que o próprio anúncio original. De Antonio o teria encorajado a optar pela segunda versão. A partir de então Warhol desenvolveria plenamente o traço frio, hiperdefinido e impessoal que se tornaria a marca das latas de sopa Campbell e de todas as chamadas Advertising Paintings desse período.

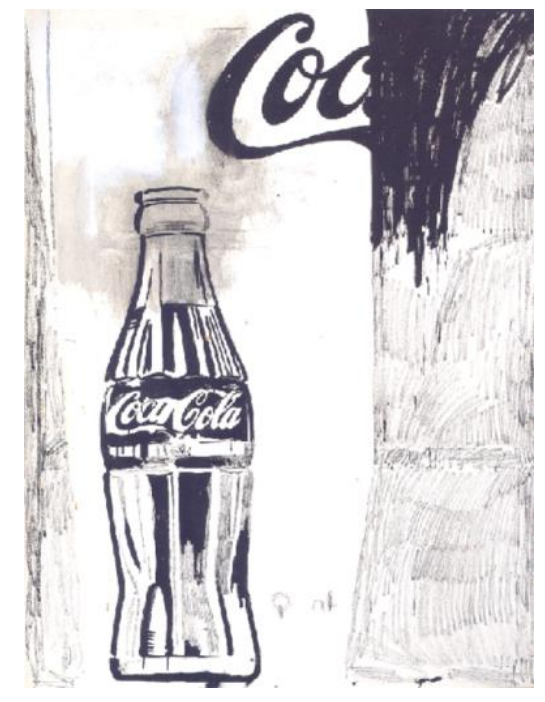

Coca-Cola (1960)

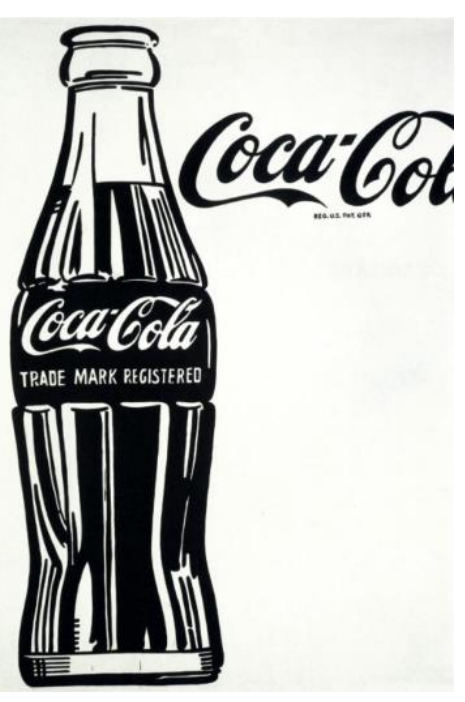

Coca-Cola $(1962)$

\footnotetext{
${ }^{8}$ O relato de Karp está em Patrick S. Smith (1981, pp. 351-52). O mesmo encontro é relatado por Warhol com menos detalhes em Popismo, pp. 15-17.
} 
No entanto, o estilo de Warhol logo sofreria uma segunda guinada com a introdução da serigrafia. Em teoria, a serigrafia seria apenas uma ferramenta facilitadora que permitiria a Warhol reproduzir a mesma imagem de maneira idêntica infinitamente: apenas o passo seguinte na constituição de um estilo anônimo, sem marcas pessoais. Mas a serigrafia gera uma mudança qualitativa na obra de Warhol: ela é outra linguagem, diferente da pintura. No fundo, há uma espécie de inversão: o gesto manual do desenho cede lugar à máquina, mas paradoxalmente essa máquina não produz o resultado perfeito que se esperaria dela. As imagens mais definidas de Warhol ainda são aquelas pintadas à mão, como os anúncios publicitários da Coca-Cola, das portas quebra-vento (storm doors), entre outros. A serigrafia deixa marcas, cria um efeito-xerox em que cada reprodução é levemente diferente da outra.

Assim, a serigrafia na obra de Warhol não é simplesmente a culminação do apagamento do estilo pessoal do artista. Ela cria um outro estilo, diverso das pinturas. Para as latas de sopa Campbell pintadas, trata-se acima de tudo de não deixar nenhum traço aparente. Mas quando a máquina assume a tarefa é preciso que ela deixe um traço. Pois a arte, a despeito talvez do que os minimalistas sonharam, ${ }^{9}$ precisa sempre deste hiato, este desajuste em relação às coisas. Um hiato no qual irá se criar uma fissura. Por mais homogêneas e congeladas que pareçam as latas de Sopa Campbell e as Advertising Paintings, elas contém em si uma travessia, evidentemente anti-climática: o gesto pessoal do pintor comprometido com o traço impessoal do design. A arte se faz nessa passagem, nesse deslocamento entre o pessoal e o impessoal, pintura e design, arte e mercadoria. Quando a máquina assume a tarefa do pintor, o resultado é diferente da uniformidade que se espera de uma linha de produção: a máquina falha, criando também esse espaço de passagem. Nas serigrafias de Warhol, é justamente no espaço criado entre as falhas que o gesto artístico se faz com força total: fantasmagoria, choque, assombro, sugestão de movimento e de tempo, tudo isso aparece nas brechas deixadas entre uma reprodução e outra das serigrafias de Warhol, nas imperfeições da máquina.

\footnotetext{
${ }^{9}$ Ver a esse respeito o provocador texto de Michael Fried, “Arte e objetidade”.
} 


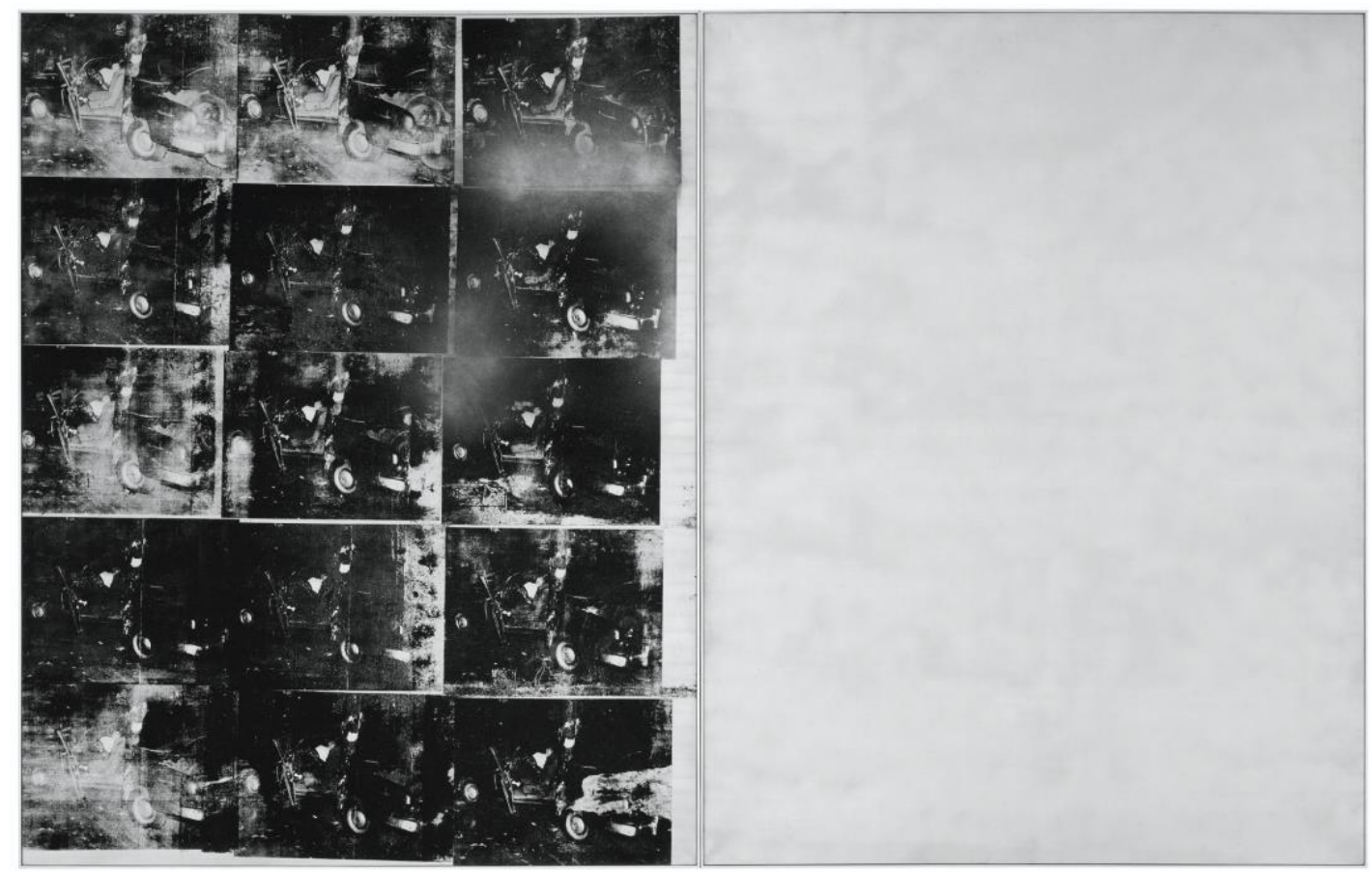

Silver Car Crash (1963): a mesma imagem é reproduzida, mas há mudanças entre uma impressão e outra

Quando Warhol passa ao cinema, meio de expressão mecânico por excelência, ele dá continuidade a esse processo: as marcas são deixadas. Inicialmente talvez por inépcia técnica, depois sem dúvida por convicção de um estilo pessoal. Há uma forte conexão entre os filmes e as serigrafias, o que é natural, já que Warhol se encanta pelos dois meios mais ou menos na mesma época. Não é difícil observar uma semelhança estrutural entre as Marilyns infinitamente reproduzidas em serigrafia e as superstars capturadas em rolos e mais rolos de película dos Screen Tests e outros filmes - muito embora o que resulte dessa práxis, seguindo a especificidade de cada meio, seja muito diferente num caso e no outro. Mas o fato é que, como as serigrafias, os filmes também incorporam em sua fatura as marcas de suas fabricação, esta espécie de "look" maquínico.

Dito de outra forma, Warhol materializa o próprio dispositivo cinematográfico no interior de seus filmes. À sua maneira, ele está próximo de Michael Snow, que em filmes como Wavelength (1967), $\leftrightarrow$ [Back and Forth] (1969) e La Région Centrale (1971) faz da própria estrutura material, mais especificamente da câmera, uma "personagem" do filme. Em Snow, o dispositivo óptico da câmera é incorporado, tornado visível enquanto tal, nas imagens dos filmes. Em Warhol, a estrutura material incorporada é aquela da película. A imagem em Warhol não é transparente, translúcida. Ela é espessa, dando a ver a matéria que a constitui: o grão da película salientado pela iluminação em alto contraste, 
as pontas visíveis de início e fim de rolo. Essa incorporação das marcas de fabricação à fatura dos filmes se dará ainda de outras formas. Quando passa a utilizar cortes, Warhol deixa visíveis os flashes que marcam a abertura e o fechamento do obturador da câmera $16 \mathrm{~mm}$ - os já referidos strobe cuts. Em muitos filmes sonoros, os créditos iniciais são ditados em voz alta, explicitando a presença de um set de filmagem no entorno da cena. Nesse sentido, os filmes de Warhol sempre são "documentários sobre a própria filmagem", para usar uma expressão de Jacques Rivette com sentido altamente materialista. O filme é uma meta-experiência: ele nos mostra imagens ao mesmo tempo em que exibe a si mesmo como objeto material.

Esse objeto material, fabricado pela máquina, deve ser evidentemente tão anônimo quanto possível: os primeiros filmes de Warhol não possuíam cartelas de créditos ou título. Em muitos casos o material bruto, tal como filmado e impresso na película, equivalia ao próprio filme acabado. Mais do que apenas mostrar as pontas dos rolos, em boa parte dos filmes realizados até 1966 Warhol deixava os rolos correrem do início ao fim (no início pequenos rolos de 3 minutos, depois rolos maiores, de cerca de 33 minutos), abdicando de uma das prerrogativas fundamentais do diretor de cinema: o poder do "corta!". Cortar nada mais é do que demonstrar satisfação ou insatisfação com aquilo que foi ou está sendo filmado. Recusando a arbitrariedade subjetiva do corte, Warhol encontrava sua forma de, no cinema, ser absorvido pela ser absorvido pela máquina.

Em termos mais profundos, no entanto, o maquinismo de Warhol se expressa pela indiferença do olhar da câmera. A câmera não se envolve emocionalmente com o que é filmado. Ao longo dos dois primeiros anos de produção, ela será sempre fixa. Nos Screen Tests e em outros filmes, essa fixidez significa confrontação, a câmera como espelho impassível que gera uma reação por parte daquele que é filmado - veremos algumas consequências desse processo no segundo capítulo. A partir de 1965, quando o movimento é incorporado à decupagem, trata-se da panorâmica ou do movimento ótico do zoom. Ou seja, a câmera permanece no tripé. A lente zoom é o olho maquínico que se estica para ver melhor. Não há um corpo humano empunhando a câmera e emanando suas vibrações sobre a imagem, como pregava Brakhage, para quem a câmera deve ser uma extensão natural do corpo e do olho humanos. Em Warhol, trata-se do inverso: é o homem que deve ser absorvido pela máquina.

O olho mecânico de Warhol está mais próximo do cine-olho de Vertov: ambos partem da mesmo concepção experimental de que o cinema serve para nos fazer ver o 
cotidiano com outros olhos, para além "do limiar as fraquezas do olho humano" (VERTOV, 1983, p. 254). Mas o "materialismo" de Warhol não é emancipatório, ao contrário: ele nos aliena no mundo gelado e maquínico onde as imagens são geradas. $\mathrm{O}$ projeto vertoviano se baseia em dois pressupostos ausentes em Warhol: 1) o cinema deve filmar o mundo, as "atualidades", o movimento das ruas; 2) a operação do cine-olho se completa com a montagem, "que organiza os minutos da estrutura da vida, vista pela primeira vez desse modo" (p. 259). Warhol abdicará prontamente tanto do mundo lá fora quanto da montagem. Se o mundo aparece, é em pequenas amostras de corpos isoladas, alienadas em seu laboratório particular.

Warhol usa a máquina como dispositivo de alienação, não de libertação. Ser absorvido pela máquina é alienar-se do mundo. Em si mesma, a máquina é alienada porque só pode registrar a exterioridade das coisas: o corpo, a pele, a superfície, jamais o indivíduo, o "eu" profundo. Ela só pode desumanizar aquilo que filma, transformando-o em imagem. Essa alienação pelo maquínico já era um modus operandi comum nas telas. Em obras como as caixas Brillo e as latas de sopa Campbell, Warhol nos colocava diante de rótulos, embalagens e anúncios de produtos copiados com o traço mais frio, impessoal e definido possível. A tentativa era a de eliminar qualquer espaço de distanciamento, qualquer hiato ou fissura em nossa relação com aquelas superfícies. Essa alienação era ainda reforçada pelo isolamento do ícone no interior da composição (que podia aparecer só ou infinitamente repetido) e por sua descontextualização dos espaços de circulação e dos sentidos originais. Apenas a efígie da mercadoria, pura superfície: rígida, fria, isolada, alienada. Assim, se um gesto crítico podia ser intuído dali, ele certamente não se revelava num movimento direto, imediato, da obra, mas surgia apenas num momento posterior, seguinte: seja num movimento intelectual de recontextualização daquela obra no espaço do museu, seja num movimento mais profundo, inconsciente, uma fissura crítica derivada da náusea provocada pela experiência alienada da superfície.

\section{Película}

A máquina-Warhol produz imagens, mas como toda máquina produtiva ela produz também objetos concretos: rolos e mais rolos de película impressa, oferecidos em toda a sua espessura, uma vez que Warhol incorpora à fatura dos filmes a materialidade do grão e das pontas dos rolos. Esse apego à materialidade do suporte sugere que, se é possível inserir Warhol numa genealogia dentro do cinema, esta talvez seja não a da vaga categoria 
de "cinema experimental", mas uma outra, mais específica: aquela dos cineastas para quem importa apenas a impressão luminosa diretamente sobre a película.

O radicalismo documental dos filmes de Warhol reside no seguinte: eles recusam toda articulação sintática ou semântica entre as imagens. Se existem articulações, como nos filmes em que há cortes ou naqueles constituídos por mais de um rolo, elas são de ordem puramente física, meras justaposições de planos: a câmera se aproxima ou se afasta da cena, o rolo é trocado etc. Dito de outra forma, não há em Warhol raccords criadores de sentido. Tudo se resolve dentro da imagem e no interior do plano. Interessa apenas o que está impresso. Se há um fora-de-campo, ele existe somente no entorno mais imediato e contíguo ao enquadramento, e de todo modo esse fora-de-campo só interessa na medida em que consegue produzir transformações no interior da imagem (as vozes em off nos Screen Tests sonoros e em Beauty \#2, a felação em Blow Job).

Assim, a encenação em Warhol é centrípeta, não centrífuga - e isso é verdade mesmo para um filme como Blow Job, como veremos no segundo capítulo (cf. "2.3. Erotismo"). A montagem, quando aparece nos filmes tardios, é um amontoado de pedaços que valem por si mesmos e em si mesmos. E ainda que os corpos apareçam cortados, o sentido vital da imagem é dado por aquilo que está presente, não ausente, pela presença literal de um rosto, um ombro ou o que for no interior do quadro. Não há lugar para a imaginação, pois não há nada além da superfície espessa da película: nenhuma profundidade psicológica nos corpos, nenhum universo diegético expandindo-se a seu redor. Estamos no reino da visibilidade pura, sob a tirania do visível e do concreto. E o concreto nada mais é do que aquilo que se imprime fisicamente no suporte. Nesse sentido, mesmo o fora-de-campo em Warhol é concreto, ele precisa imprimir-se de alguma forma, seja influenciando a cena, seja gravando-se literalmente na banda sonora, uma vez que nos filmes de Warhol o som é sempre direto, não há edição na pós-produção. Nesse aspecto, à sua maneira, Warhol é tão escrupulosamente materialista quanto o casal StraubHuillet.

Todavia, mais do que um documentarismo ou um materialismo, palavras carregadas de sentidos muito amplos, esse projeto de cinema fundado na confiança da impressão luminosa das coisas talvez seja melhor definido pelo "lumièrianismo" de que falava Mekas: esse retorno a um cinema em que o código dá lugar à fascinação pela imagem que se imprime, que existe em si mesma e por si mesma. Lembramos aqui da anedota de George Meliès, que, diante do Repas de bébé (1895) dos Lumière, 
maravilhava-se não com a encenação, mas com as folhas da árvore que balançavam ao fundo, a captação dessa realidade fugidia, impressa no fotograma por acidente.

Nessa genealogia lumièriana do cinema, dos cineastas que pensam o cinema como mera impressão luminosa, poderíamos incluir, além de Warhol, igualmente Julio Bressane, Philippe Garrel, Jean-Claude Rousseau, entre outros. Se Warhol confiava na fotogenia, Bressane - que não por acaso cita os Screen Tests em Lágrima-pantera, a míssil (1972) — insiste frequentemente na ideia de fotodrama: "a ação da luz, ação trágica da luz, [que] define contornos, cria formas, inventa coisas, escreve além de si, dramatiza" sobre a superfície do fotograma (2011, p. 7). No cinema de Bressane, a cena e os atores em geral são entendidos como matéria plástica, e essa plasticidade muitas vezes nos deixa entrever seu rastro luminoso — é por isso que é difícil falar numa “diegese" (consistente, realista) em Bressane, pois o que interessa a ele é este mundo transposto para a película, tornando matéria plástica pela luz. Notemos que Mekas também falava de um mundo "transposto", "eletrificado", em Warhol. Mas se em Bressane esse voto de fé no cinema como impressão luminosa é uma sensibilidade de saída, um "chão" em torno do qual se articulam outras operações formais, Warhol, em seu radicalismo, reduz tudo ao "grau zero": ele hipoteca seu cinema a esse registro do mundo tão simples quanto "em si mesmo", pura impressão da luz.

Se falamos aqui de um "retorno a Lumière" por parte desses cineastas, é preciso esclarecer, contudo, que este é um retorno "de segunda mão”, consciente de seu tempo. O que se entende hoje pelos filmes dos irmãos Lumière, e que a anedota de Meliès deixa entender, é que seus autores pensavam o cinema como abertura para o mundo e registro da realidade - o mundo em todo o seu esplendor: o vento, a natureza, os vapores, o ar. Warhol, Bressane e Garrel surgem nos anos 1960 e estão mais preocupados com uma questão fotoquímica (o fotodrama de Bressane): a película é pensada não exatamente como transparência, mas como superfície espessa onde as coisas se gravam. Assim, as coisas são "puras" (pura inscrição luminosa), mas paira sobre elas sempre uma consciência escrupulosa. E em Warhol essa consciência nada mais é do que seu ambicioso projeto de tornar-se máquina: é preciso tornar-se máquina, comprometer o fazer artístico numa imensa práxis impessoal que inclui, no limite, a própria estetização da vida, para registrar as coisas tão simples quanto são "em si mesmas". A seguir, veremos um pouco das origens e do contexto em que surge esse ambicioso projeto marquínico. 


\title{
Influências
}

Thierry De Duve observa que a ideia do pintor como máquina, como uma placa retiniana onde as coisas do mundo vêm se imprimir, remonta à alta modernidade, ao século XIX:

\begin{abstract}
Desde que Delaroche, Champfleury ou Baudelaire expuseram o medo, inspirado pela fotografia, de ver o pintor substituído por uma máquina, os pintores modernos - os grandes, aqueles que merecem ser chamados de vanguardistas - responderam manifestando seu desejo de tornar-se uma. Courbet, professando que "nada do que se imprime na retina está fora do domínio da pintura", foi o primeiro a dar a ela uma definição estritamente fotográfica. Manet, que simplificava o chiaroscuro e captou com êxito o espanto inexpressivo de seus modelos como se fossem atingidos pela luz de magnésio, fazia a tela estremecer com uma paixão só equiparável à passividade da imagem automática. Monet, como se fosse além da velocidade da fotografia, registrou em suas catedrais de Rouen e seus palheiros a luz instantânea como se ela atingisse e se imprimisse sobre a tela. Seurat, num desenvolvimento contemporâneo à invenção do autocromo pelos irmãos Lumière, digitalizou a paleta e mecanizou a mão. Cézanne, que admirava Monet por não ser "senão um olho" e Courbet por não saber o que pintava embora produzisse disso a mais exata semelhança, também discursava [...] que "o cérebro livre do artista quando trabalhava deveria ser como uma placa fotográfica, uma simples ferramenta de registro". (DE DUVE, 1989, p. 10)
\end{abstract}

Em Warhol, esse projeto será talhado, evidentemente, com o contorno específico de seu tempo: aquele da arte pop e sua relação com a cultura de massa, seu estatuto de vanguarda tardia e tudo o que ela prepara para a chegada do pós-modernismo. Aqui, o desejo de tornar-se máquina não se expressa mais apenas numa práxis ética individual do artista. Ele ganha uma estranha dimensão performativa que, se confrontada à tradição de Courbet, Cézanne ou Monet invocada por De Duve, ganha ares de um verdadeiro pastiche pósmoderno.

Acima de tudo, Warhol era um artista que respirava o ar de seu tempo. Nesse sentido, a gestualidade impessoal, fria, distanciada de suas obras não deve ser entendida apenas como expressão coerente de seu projeto maquínico. Mais do que qualquer coisa, ela é fruto de um temperamento artístico que ecoa seu momento histórico específico: aquele da arte norte-americana entre o fim dos 1950 e o início dos 1960. Esse momento tem como evento principal o esgotamento do expressionismo abstrato, com sua sensibilidade tipicamente modernista, e o aparecimento das chamadas neovanguardas a partir dos anos 1960, como a arte pop, o minimalismo, a arte conceitual e posteriormente o movimento Fluxus. Grosso modo, o início dos anos 1960 vê saírem de moda o "espaço 
transcendental" 10 e a gestualidade heroica que era a marca de pintores como Jackson Pollock e Mark Rothko e a ascensão, no mundo da arte norte-americano, de artistas como Frank Stella, Jasper Johns e Robert Rauschenberg, que encarnavam, cada qual à sua maneira, uma abordagem mais pragmática e distanciada do objeto artístico. O gesto deixa de ser entendido como expressão de uma caligrafia pessoal e o artista se torna sobretudo um organizador de elementos: daí a importância que a espacialidade ganha em Stella, Johns ou Rauschenberg, por exemplo.

Esses artistas orbitavam num círculo muito próximo ao de Warhol, e podemos encontrar uma clara influência dos alvos e bandeiras de Johns sobre obras como Telephone (1962), os Dance Diagrams ou mesmo as latas de sopa Campbell de Warhol, tanto pela banalidade dos motivos escolhidos quanto por sua centralidade na composição. ${ }^{11} \mathrm{O}$ que nos interessa aqui, no entanto, é pensar uma sensibilidade geral que é anterior a Warhol e da qual, de certa forma, ele é produto. Essa sensibilidade é aludida pelo próprio Warhol no primeiro parágrafo de Popismo quando diz que Johns, Rauschenberg e outros "já haviam começado a trazer a arte de volta da introspecção. Então a Pop Art pegou o interior e voltou para o Exterior, pegou o Exterior e voltou para o interior" (2013, p. 11). A exterioridade passa a ser entendida como ponto de partida (no lugar do impulso interior), num projeto artístico comprometido com o visível e com a dimensão concreta do objeto de arte. Esse espírito pragmático, não heroico, está longe de ser uma peculiaridade da arte pop. Ela é comum a outras tendências artísticas da época, e na realidade encontraria sua expressão mais bem acabada num outro movimento: o minimalismo.

Aliás, mais do que com a pop, os filmes do Warhol talvez guardem relações mais profundas com o próprio minimalismo. Na visão de Peter Wöllen, "foi o minimalismo que permitiu a Warhol liberar a orgia do camp" em seus filmes, canalizando-a "dentro de uma estética rigorosa e austera" (1989, p. 17). As afinidades entre Warhol e o minimalismo podem ser pensadas sob muitos prismas. A primeira é via John Cage: a influência direta de Cage e sua filosofia zen sobre diversos artistas próximos de Warhol (Rauschenberg, Merce Cunningham e o próprio Mekas) certamente cria um vaso comunicante entre a metafísica cageana da repetição e do vazio e, por exemplo, o elogio do tédio de Warhol - um tédio que se expressa plenamente em seus filmes por meio de

\footnotetext{
${ }^{10}$ Cf. Foster, 2014, p. 53.

${ }^{11}$ Para uma análise detalhada das relações entre Johns e Warhol ver a dissertação de Tiago Mesquita (2009, pp. 100-11).
} 
uma insossa "teatralização do cotidiano". ${ }^{12}$ No entanto, mais do que espiritual, a proximidade de Warhol com o minimalismo se revela também, e sobretudo, em termos formais, em seu apego a uma estética literalista e calcada no procedimento serial.

Verifiquemos essa influência de um ethos minimalista num filme específico: Eat, em que Warhol registra o rosto de Robert Indiana mastigando pedaços de um cogumelo por um longo tempo. Como nos outros filmes de Warhol desta época, o filme se inicia anonimamente, sem cartelas de título ou créditos. Vemos surgir primeiro a ponta branca, velada, que marca o início do rolo, sugerindo que o filme corresponde rigorosamente ao material bruto filmado. Passada ela, entra o rosto bem iluminado de Robert Indiana, que mastiga lentamente (os movimentos são tornados mais lentos que o normal devido à projeção a 16 fotogramas por segundo). O tempo passa. Não há som. A cada quatro minutos mais ou menos a figura se dissolve numa tela branca que invade a imagem: são as pontas veladas do negativo que marcam o início e o fim de cada rolo. Passados esses fotogramas brancos, a figura reaparece, na mesma posição de antes, dando continuidade a seu moroso ato de comer. E assim sucessivamente, por cerca de 40 minutos. No fim, a imagem é novamente tomada pelos fotogramas brancos que marcam o fim do rolo. Mas dessa vez a figura não retornará. Fim do filme: sem anúncio, sem créditos.

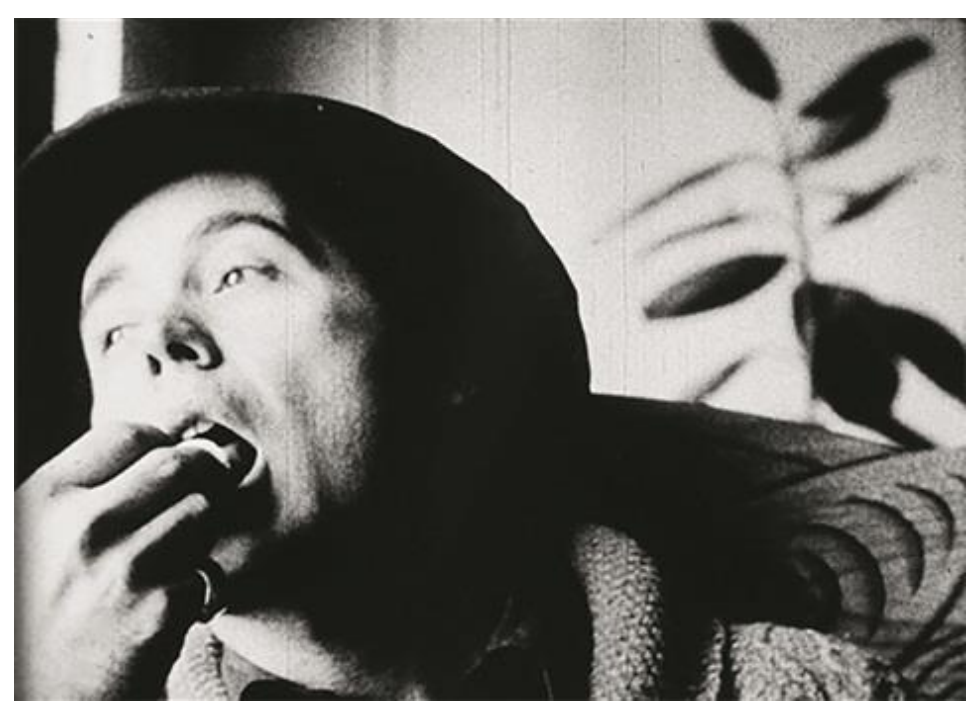

Eat (1964)

A primeira coisa que chama atenção é a unidade do filme. Há apenas uma ação, que se prolonga rolo após rolo de maneira constante, sem variações de enquadramento ou de

\footnotetext{
${ }^{12}$ Muito embora essa influência, como é típico em Warhol, não venha sem um ar de pastiche.
} 
iluminação. O redutivismo do filme ecoa de longe a aspiração minimalista da peça una, sem partes. $\mathrm{Ou}$, melhor, de partes regulares justapostas segundo um padrão. Numa escultura, o padrão se desenvolve espacialmente, mas no caso do filme de Warhol esse padrão é temporal: corresponde à duração de cada rolo. O tempo é, portanto, serializado. É verdade que Eat tem uma figura e que, apesar do gestual repetitivo, ela apresenta pequenas variações na inclinação de sua cabeça, que geram também mudanças na iluminação: essas variações contingenciais estariam para o filme como as irregularidades intrínsecas ao estampado da madeira estariam para as caixas de Donald Judd, tornando duas tábuas cortadas idênticas objetos diferentes — assim como dois rolos de Eat são objetos diferentes. Variações intrínsecas do material, em suma, à revelia das intenções do autor. O filme tão somente como um desdobramento de sua forma, com seu conteúdo reduzido ao mínimo.

Apesar de exagerada, a descrição acima serve para ressaltar a afinidade espiritual de Warhol com o imaginário minimalista. ${ }^{13}$ No cinema, esse imaginário na realidade iria fecundar não exatamente em Warhol, mas num outro grupo de filmes: o chamado cinema estrutural. O cinema estrutural foi uma tendência de cinema de vanguarda particularmente prolífica na segunda metade dos anos 1960 em Nova York e à qual costumam ser associados cineastas como Michael Snow, Ernie Gehr, Hollis Frampton e Paul Sharits. O termo foi cunhado por P. Adam Sitney, que, no texto que batiza a tendência, não por acaso aponta Warhol como uma espécie de precursor. ${ }^{14}$ Embora cheguem a ser contemporâneos, Warhol e os estruturais possuem conexões apenas indiretas: as principais obras de Snow, Frampton, Gehr e Sharits são feitas entre 1966 e o início dos anos 1970, quando a produção cinematográfica de Warhol já dera uma guinada rumo a sua fase sexplotation. No entanto, há certa semelhança entre os filmes de Warhol e os estruturais, que talvez seja menos fruto de uma influência direta do que de uma sensibilidade comum, cujo fundo se conecta também à arte minimalista.

Uma das principais marcas dos filmes estruturais era a preocupação com o formato global da obra (que Sitney, em seu artigo, chama de shape), o que remete à busca pela unicidade da arte minimalista. Esse formato global determinava o andamento interno do filme, que se desenvolvia por meio de padrões que respondiam a essa estrutura geral.

\footnotetext{
${ }^{13}$ Yvonne Rainer provavelmente não daria o selo minimalista aos filmes de Warhol. Algumas passagens de seu "No Manifesto" de que os filmes de Warhol poderiam ser acusados: "Não ao glamour e à transcendência da imagem da estrela. Não ao heroico. Não ao anti-heróico. Não às imagens degradadas. [...] Não ao camp".

${ }^{14}$ Sitney, "Structural Film", originalmente publicado na revista Film Culture no 47, verão de 1969.
} 
O conteúdo era "mínimo": o "assunto" desses filmes frequentemente era a própria experimentação sensível desses padrões. Em alguns casos, como nos chamados filmes de flicker, recusava-se a própria figuração e o filme se limitava a uma alternância rítmica entre fotogramas opacos (pretos, brancos e coloridos), que dão a impressão de piscar com a projeção.

Longe de constituírem um grupo coeso, os estruturais eram artistas oriundos de diversos lugares e práticas artísticas da cena nova-iorquina que acabaram por convergir numa mesma sensibilidade emergente no início dos anos 1960, interessada "em padrões de repetição e variação; uso de estruturas não hierárquicas". Outras características presentes no trabalho desses artistas e que ecoavam a sensibilidade da época eram a investigação reflexiva da "natureza do meio artístico, dos materiais e do modo como são percebidos; [a] exploração das modalidades de percepção, cognição e memória dos espectadores; [o] repúdio à expressividade e formas psicodramáticas; questionamento e eventual rejeição ao uso de memórias e símbolos"; entre outras (DUARTE, 2015, p. 50). ${ }^{15}$
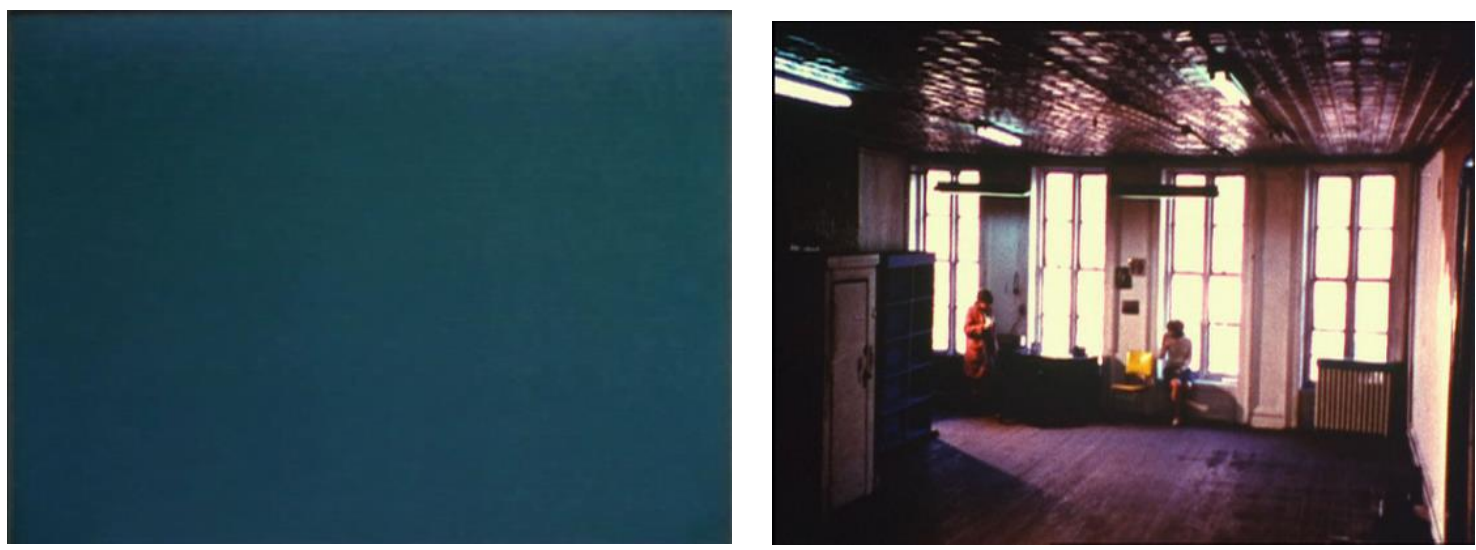

À esquerda, fotograma opaco em N:O:T:H:I:N:G (1968), de Paul Sharits, exemplo de filme de flicker. À direita, Wavelength (1967), de Michael Snow

Por serem voltados para a exploração do próprio meio, os filmes estruturais frequentemente procedem por uma abordagem materialista, como nos já referidos filmes de flicker. Paul Sharits, um dos principais nomes dessa tendência, observava em seu manifesto "Palavras por páginas", de 1972, que há duas maneiras de experimentar um filme: como objeto (isto é, o rolo de película, que, ressalta Sharits, não seria uma

\footnotetext{
${ }^{15}$ Para um entendimento das relações entre cinema estrutural e minimalismo, ver Duarte, 2017.
} 
"partitura", mas o filme em si mesmo) ou como "processo temporal, enquanto é 'projetado' no suporte estável da tela” (2015, p. 160). Nossa tendência como espectadores é ver o filme apenas como processo temporal, as imagens que surgem e desaparecem na tela, ignorando a dimensão material do meio, a estrutura do "espetáculo". Recalcamos a presença da câmera, seus movimentos, a passagem de um fotograma a outro, as mudanças de foco. Ou, melhor: interpretamos esses elementos não como estrutura material, mas como forma.

Aqui vale um pequeno esclarecimento. Por "forma" entendemos as operações artísticas visíveis num filme ou obra de arte. Toda forma é resultado de um trabalho material: a artista enforma a matéria do mundo, criando um objeto artístico. Esse objeto artístico em nenhum momento deixa de ser material: ele guarda essa estrutura material enformada, que pode ser mais ou menos ressaltada na fatura final da obra. Tradicionalmente, o cinema tende a recalcar essa estrutura material, orientando-se para a representação. ${ }^{16}$ Toda obra de arte pode ser vista, portanto, como estrutura material e como forma, que são duas faces de uma mesma moeda e correspondem às duas formas de experiência apontadas por Sharits. A diferença entre elas é que "forma" implica numa operação de sublimação em relação à estrutura material: para ver um objeto como "arte" devemos vê-lo como algo mais do que uma mera estrutura material, precisamente como uma forma que — na falta de termo melhor — "expressa" alguma coisa. Realizamos uma operação mental de transfiguração metafísica ao passarmos da estrutura material à forma. Um movimento de câmera se torna uma forma que expressa algo por meio dessa operação mental do espectador. Mas ele permanece sendo também sempre um movimento, tão somente um movimento, literalmente, fisicamente, sobretudo se não realizarmos essa operação mental.

Procedendo em uma abordagem materialista, muitos dos cineastas estruturais irão trazer essa estrutura material usualmente recalcada para o centro da experiência. Eles fazem isso explicitando no interior das obras as duas maneiras de experimentar um filme descritas por Sharits. Assim, os filmes de flicker criam sua forma na passagem (normalmente recalcada) de um fotograma a outro. Já falamos de Michael Snow: em Wavelength, o zoom é ao mesmo tempo a estrutural material e o formato global do filme, sua forma. A câmera é o que nos possibilita ver, mas é também "personagem" do filme. Perceber a presença da câmera e o zoom enquanto tais é parte decisiva da experiência de

\footnotetext{
${ }^{16}$ Representação referendada pelo "realismo indicial" do cinema: a câmera como janela para o mundo etc.
} 
identificação ao inorgânico, ao maquínico, proposta pelo filme. ${ }^{17}$ Nesses filmes, estrutura material e forma não são dissociadas por uma operação mental: elas são uma coisa só, ambas são visíveis e oferecidos para o espectador enquanto tais.

Nesse literalismo, os estruturais estão muito próximos dos minimalistas. Em alguns trabalhos de Frank Stella a dinâmica formal interna da obra frequentemente se limita à repetição, em listras, do padrão determinado pelo formato da tela, seu perímetro exterior, enquanto Donald Judd em seu texto "Objetos específicos" propõe uma identificação plena e radical entre estrutura material e a forma da obra. No fundo, o caminho que a oposição de Sharits nos deixa ver, entre o filme como objeto e o filme como experiência, nada mais é do que aquele delineado pelo artigo de Michael Fried (2002), "Arte e objetidade", que iria censurar os minimalistas - numa via argumentativa que não cabe comentar aqui - justamente por essa dissolução da obra de arte em sua condição de objeto.

É sobretudo pelo trabalho materialista com o tempo que Warhol se aproxima dos estruturais - e, consequentemente, dos minimalistas. O tempo, ao ser serializado, se torna concreto. Ele deixa de ser gerado pelo fluxo natural dos eventos internos do filme. Ao invés disso, o tempo passa a ser concebido como forma sólida dada a priori. São os modelos dos Screen Tests que têm de se adaptar ao tempo do rolo, e não o contrário. Quando deixa os rolos correrem até o final, mostrando as pontas veladas, Warhol não está simplesmente nos deixando entrever a estrutura material do cinema. Ele está abdicando do "poder de corte", deixando o rolo correr independentemente do que aconteça em cena. Assim, a estrutura material do rolo determina a forma temporal do filme. E Warhol está colocando essa estrutura material no centro de seu projeto estético. Como os estruturais, ele sobrepõe e identifica uma operação formal (o ponto de corte de um plano) à estrutura material da obra (o fim do rolo de negativo), criando uma relação tautológica entre estrutura material e forma fílmica que é explicitada ao espectador. No caso de cada um dos Screen Tests, ele identifica a obra de arte "filme" ao "objeto" filme (o rolo de película), dispensando até mesmo qualquer marca de identificação ou assinatura visíveis.

Warhol e os cineastas estruturais partilham de uma mesma sensibilidade objetiva, não emocional, comum também aos minimalistas e outras tendências artísticas do

\footnotetext{
${ }^{17}$ Há uma interpretação tradicionalmente aceita de Wavelength, proposta por Annette Michelson (2015), de que o zoom no filme corresponderia ao movimento da consciência, da atenção, humana. Essa interpretação nada mais é do que a típica operação de sublimação que discutimos logo acima. Interpretar o movimento ótico da câmera como representação da consciência implica, muito simplesmente, em deixar de vê-lo como movimento material. Portanto, nós não subscrevemos essa interpretação.
} 
período, mas têm projetos distintos. O projeto do cinema estrutural é "experimental" no sentido mais puro do termo: seu objetivo é pôr a estrutura material no centro do filme para explorar as possibilidades intrínsecas ao meio que haviam sido abandonadas pelo paradigma realista-representativo do cinema. O que é possível criar na passagem sempre recalcada, seja pela ficção, seja pelo documentário - entre um fotograma e outro? Já o cinema de Warhol, se pode ser definido como "experimental”, é numa chave oposta: pois ele se orienta para o mundo, para o "fora". Ou seja, enquanto os estruturais se voltam para o que é intrínseco ao cinema - e, no limite, sonham com a eliminação da realidade diante da câmera - , Warhol se volta para o extrínseco. $\mathrm{O}$ filme serve para registrar alguma coisa. Mais do que isso: ele se esforça e faz de tudo para parecer tão somente o mero registro dessa coisa, o "mais simples aparelho".

\section{Amadorismo}

A máquina-Warhol se equilibra num paradoxo. Por um lado, ela anseia uma espécie de produtividade industrial, tornada explícita quando Warhol nomeia seu ateliê de Factory. A "fábrica" produz telas e filmes em larga escala. Seu objetivo: ocupar espaços, ${ }^{18} \mathrm{com}$ Warhol atuando como uma espécie de produtor, gerenciando assistentes, lançando superstars para os filmes. Por um lado, a Factory é o primeiro passo de Warhol em direção à ideia do business artist, que se completa com o agenciamento do Velvet Underground e, mais adiante, com empreendimentos como a revista Interview. Por outro lado, é surpreendente que o movimento de Warhol em direção ao cinema não tenha nenhum anseio comercial visível nos filmes em si: estes são notadamente pouco palatáveis, dando frequentemente a impressão de até mesmo tripudiarem do público (Blow Job, Sleep, Empire). Um movimento em direção a um cinema comercial seria feito apenas sob influência de Morrissey, e ainda assim o resultado de todos os filmes em que Warhol põe a mão como diretor é sempre muito aquém dos padrões comerciais (basta comparar o ritmo moroso de Bike Boy e Lonesome Cowboys com o dos filmes da trilogia de Morrissey).

\footnotetext{
18 "Sempre acho que quantidade é a melhor medida para tudo (porque você está sempre fazendo a mesma coisa, mesmo que pareça que você está fazendo outra coisa), então eu tenho em vista virar um artista 'espacial'. Quando Picasso morreu, li numa revista que ele tinha feito 4 mil obras-primas em sua vida e pensei: 'Nossa, eu podia fazer isso num dia'” (WARHOL, 2008, pp. 168-69).
} 
É que quando decide fazer cinema, mais do que abandonar as artes plásticas em direção a um novo campo, Warhol talvez tenha feito o caminho inverso: ele traz o cinema para dentro do ateliê. O cinema é apenas uma mídia a mais no contexto experimental da Factory. E a "lógica industrial" se torna uma práxis artística, mais do que um sistema de produção com fins comerciais. O fato é que, como empreendedor, Warhol tem táticas bem mais sofisticadas do que um sistema de produção industrial tradicional: por exemplo, capitalizar a própria imagem, misturar arte e vida, fazer-se presente e explorar a mídia.

Assim, em seu espaço, a Factory parodia o sistema de produção dos estúdios, criando uma mimese degradada do que foi a Hollywood clássica (Warhol é o produtor, o mandachuva, the boss: a Factory tem funcionários fixos, produz muitos e muitos filmes, tem suas próprias “estrelas" cativas). O resultado é também paródico: filmes rudimentares em $16 \mathrm{~mm}$, em que salta aos olhos o amadorismo, a inépcia técnica, a falta de ambição formal. Consequência do paradoxo: a "fábrica" realiza produções artesanais, na beira do amadorismo.

Esse paradoxo industrial-amador se reflete no interior dos próprios filmes. Pois, por um lado, os filmes de Warhol frequentemente se voltam para motivos clássicos do cinema amador: o cotidiano (Sleep, Eat, Drink) e os retratos. Por outro, a formalização dessas obras as afasta completamente de um registro íntimo, orgânico com esses motivos. Ao contrário, a máquina-Warhol é impessoal, gelada, submete seus retratados a uma tortura, desfuncionaliza o cotidiano, isola-o num laboratório, no estúdio. Apesar de os filmes manterem uma relação muito direta e descodificada com aquilo que registram, tudo chega a nós suspenso nesse olhar frio e maquínico da câmera.

Jeff Wall, em seu ensaio "Marcas da indiferença", vê o aspecto amador dos filmes de Warhol como uma construção. Segundo o autor, a amadorização foi uma das formas encontradas pela fotografia para se inserir na lógica modernista da autorreflexividade crítica. Na concepção modernista greenberguiana, essa lógica autorreflexiva faria cada arte tender a um redutivismo, uma eliminação das características supérfluas (no caso da pintura, da figuração) em direção à especificidade de cada meio. Wall se coloca um problema teórico: uma vez que para a fotografia é impossível se livrar da figuração, como ela pode chegar à sua especificidade? A resposta seria através de uma "grande redução" dada pela "experimentação com o 'não estético', com a 'aparência de não arte', a 'condição de não arte"”. O trabalho de certos fotógrafos, seja com uma estética amadora, seja também com o que Wall chama de fotoconceitualismo, representaria justamente esse tipo de experimentação. Ele também vê a adesão de Warhol ao maquínico, sua tendência 
a um redutivismo radical, nos termos dessa mesma "amadorização". Falando sobre Kiss, Eat e Sleep, ele afirma que o amadorismo nesses filmes

se faz visível como modalidade ou o estilo fotográfico que, em si mesmo, indica o afastamento da fotografia de três grandes normas da tradição pictórica ocidental - a formal, a técnica e a relacionada ao alcance do tema. Warhol viola todas essas normas ao mesmo tempo, como Duchamp fizera antes com o ready-made. [...] A substituição warholiana da ideia do artista como produtor qualificado pela ideia do artista como consumidor de novas engenhocas de produção de imagem foi apenas a encarnação mais óbvia e marcante do que poderíamos chamar de novo amadorismo, o qual marca uma boa parcela da arte dos anos 1960 e começo dos 1970. (WALL, 2017, p. 177-178)

Nesse sentido, tal como as latas de sopa Campbell e as caixas Brillo, a estética amadora dos filmes de Warhol, o "mais simples aparelho", seria apenas mais uma forma de testar os limites da arte. O redutivismo de Warhol espelha "o desejo da vanguarda [...] de ocupar o limite da estética, seu ponto de fuga" (WALL, 2017, p. 179). Sobretudo, é importante notar que se trata de uma construção: não de um amadorismo puro e simples, que tende a apostar num engajamento emocional e/ou ético com a realidade, mas de um maquinismo frio que suspende as imagens e nos faz contemplá-las de um outro ângulo, provocando estranhamentos em relação à banalidade que os filmes mostram.

\subsection{Dispositivo e prazer de olhar}

Uma questão de fundo permeia este trabalho: a máquina warholiana possui um olhar próprio? Ou sua câmera é um mero "olho de vidro", ao qual o autor teria aderido completamente, dissipando-se? Essa última impressão talvez venha principalmente do fato de que os filmes de Warhol não se articulam exatamente nos termos de uma miseen-scène, mas de um "dispositivo". Isso porque a própria palavra mise-en-scène, que literalmente quer dizer "pôr-em-cena", pressupõe uma instância ativa, que atua controlando todos os elementos da unidade orgânica do filme. Dispositivo, no sentido que estamos utilizando, supõe, ao contrário, uma instância que alterna entre o controle e a passividade. A definição é de Cezar Migliorin:

$\mathrm{O}$ artista/diretor constrói algo que dispara um movimento não presente ou pré-existente no mundo, isto é um dispositivo. É este novo 
movimento que irá produzir um acontecimento não dominado pelo artista. Sua produção, neste sentido, transita entre um extremo domínio — do dispositivo - e uma larga falta de controle — dos efeitos e eventuais acontecimentos.

[...] O criador recorta um espaço, um tempo, um tipo e/ou uma quantidade de atores e, a esse universo, acrescenta uma camada que forçará movimentos e conexões entre os atores (personagens, técnicos, clima, aparato técnico, geografia etc.). [...] O dispositivo é uma experiência não roteirizável (MIGLIORIN, 2005)

A alternância entre domínio inicial e falta de controle sobre os resultados, bem como a ideia do autor como organizador mais do que como um metteur-en-scène que controla os elementos da encenação e se expressa por meio deles, tudo isso cai como uma luva para os filmes de Warhol. É a perfeita definição da máquina: cria-se uma "setagem", estabelece-se os parâmetros e aperta-se o botão. Os Screen Tests são a expressão perfeita dessa ideia: a cena é armada (câmera, iluminação), Warhol dá eventualmente uma indicação preliminar ("não se mexer") e resultados são, de certa forma, imprevisíveis. Em alguns casos, a entropia pode tomar conta da cena, como no rolo de Chelsea Girls em que Ondine abandona o quadro depois de se revoltar com a moça com quem contracenava. Optar pelo dispositivo é justamente apostar nesse risco, nesse jogo, apostar que algo pode ou não se passar.

Mas o dispositivo implica numa ausência de olhar? Desde que se começou a falar em "dispositivo" no cinema é comum opor-se, de um lado, cineastas do dispositivo e, de outro, cineastas que exercem seu olhar sobre o mundo. O dispositivo é um método de captura da realidade por meio de uma armadilha. Ele implica que, estabelecido o sistema, a própria realidade faça o resto do trabalho por si mesma. Isso no caso dos documentários. Em filmes de ficção, em que essa "realidade" cede lugar a uma encenação, o dispositivo implica na determinação das operações formais por um sistema pré-estabelecido, a decupagem sendo uma mera execução desse sistema. ${ }^{19}$ A pergunta é: como uma câmera atada por um sistema prévio pode exercer um olhar sobre aquilo que filma? O "sistema" de Warhol é conhecido: a câmera posicionada frontalmente à cena, abandonada imperturbável e indiferente, recusando o corte, deixando o rolo correr até o fim independentemente do que aconteça na cena.

\footnotetext{
${ }^{19}$ Aqui poderíamos citar, por exemplo, Elefante (2002), de Gus Van Sant, filme de ficção, mas no qual a decupagem é determinada por um sistema prévio cujo funcionamento independe das exigências dramáticas de cada cena. $\mathrm{O}$ impacto do filme reside justamente no desencontro entre essa decupagem pré-determinada e as exigências dramáticas não cumpridas pela câmera. Quanto aos documentários, um bom exemplo é Jogo de cena (2007), de Eduardo Coutinho.
} 
No entanto, negar que os filmes de Warhol expressam uma sensibilidade pessoal, que a realidade transposta pela câmera vem moldada por um olhar, seria negar a própria evidência. As imagens de Warhol possuem um temperamento, elas têm um gosto (frequentemente nauseante) que é próprio a uma sensibilidade. Esse gosto e esse temperamento se perdem nos filmes de Paul Morrissey, que, como dissemos, reconstituem o estilo-Warhol apenas num plano teórico: há os strobe cuts, há o fascínio pelo corpo, há, em alguns casos, até mesmo o tempo como questão (Flesh é um dia na vida de Joe D’Allessandro). Mas não há a mesma flacidez, a mesma náusea, a mesma inconsistência dos papéis, a mesma experiência do tempo.

O próximo capítulo se propõe a pensar como essa sensibilidade e esse gosto pessoal ganham corpo nos filmes para além de sua máscara maquínica. Partimos da tese de que os filmes de Warhol são, para além de qualquer interesse experimental e formal, filmes essencialmente sobre o prazer de olhar. Prazer de olhar o outro. Eles constroem um dispositivo, a máquina, com a única motivação de nos permitir olhar e olhar para aquelas figuras.

O dispositivo, por sua própria natureza, cria uma situação de espectatorialidade duplicada: ele nos mostra a realidade, mas também uma moldura, a interface do "jogo" e suas regras. Em outras palavras, o dispositivo sempre nos mostra que está mostrando a realidade. Em Warhol, a exacerbação da materialidade e o abandono a um tempo da contemplação eventualmente nos suscitam essa consciência de estarmos vendo, de que estamos sendo forçados a ver.

Essa duplicidade do dispositivo nos leva de volta às relações de Warhol com um cineasta estrutural, Michael Snow. Talvez mais do que qualquer outro cineasta, Snow coloca em cena o dispositivo, aqui entendido como a estrutura material do filme, mais especificamente a câmera, o dispositivo óptico. Em filmes como Wavelength e $\nleftarrow \rightarrow$ [Back and Forth], vemos as coisas (um apartamento, uma sala), mas sobretudo vemos que estamos vendo. Snow e Warhol partilham do mesmo interesse pelo maquínico, o mesmo desejo de absorver o espectador numa máquina de visualidade pura. A diferença é que Snow tem um projeto formal bem resolvido: ele torna a câmera personagem e nossa força a nos identificarmos ao dispositivo óptico. Em outras palavras, o maquinismo de Snow é um elemento interno aos filmes. O diretor controla a cena e se serve da máquina para criar linhas de força no universo do filme: o cadáver, a conversa telefônica, tudo é deliberadamente plantado na cena a fim de criar contraste dramático com a impassibilidade da câmera. Já o maquinismo de Warhol está frouxamente disseminado 
numa postura geral em relação ao fazer fílmico, uma atitude passiva: o rolo corre até o fim, a película se mostra, a cena foge ao controle. Há uma ânsia de olhar que contamina os filmes, mas que não se resolve exatamente no plano formal. Snow quer fazer com que nos identifiquemos à câmera (e tem um plano para isso), Warhol quer ele mesmo se identificar à câmera. O projeto formal que deriva daí evidentemente só pode ser esdrúxulo.

Daí a dificuldade, apontada por Adriano Aprà e Enzo Ungari (1971), para a crítica falar dos filmes de Warhol, uma vez que não é mais possível "examinar, nesses filmes, a ‘mensagem', a ‘ideia', o ‘projeto', o ‘estilo, o ‘conteúdo', a ‘forma’”. Não há mensagem, não há forma, não há estilo, não há conteúdo, mas apenas uma máquina com uma única função: nos fazer olhar. Pois essa máquina (a máquina do cinema), no limite, não serve para outra coisa. O redutivismo de Warhol no fundo tem como objetivo nos recolocar diante da essa função primordial do cinema: nos fazer ver. Inicialmente há um corpo, há alguém que olhamos, mas com o passar do tempo, quando o objeto se esgota e já cansamos de olhar para ele, resta o puro gesto isolado de olhar. É aqui, quando esse limite é ultrapassado, que os filmes se tornam à sua maneira também filmes "sobre o olhar". Isso deriva do fato de que Warhol constrói um dispositivo com a única motivação de nos fazer olhar e olhar.

No entanto, essa máquina não encarna apenas uma indiferença branda: ela é caprichosa, às vezes brutal. À sua maneira, ela deseja, como veremos no capítulo que se segue. É no erotismo flagrante dos filmes de Warhol que uma sensibilidade e um gosto pessoal se manifestam. Seria impossível falar em "temperamento pessoal" nos filmes de Michael Snow, e fica clara aqui a diferença entre Warhol e um cineasta estruturalmaterialista em sentido estrito. Eis, então, o projeto não exatamente formal, mas estético de Warhol no cinema: aderir à máquina e desejar através dela. Nesse sentido, não há contradição ou paradoxo entre um estilo maquínico, de um lado, e uma sensibilidade, temperamento e gosto pessoal, de outro: pois a máquina participa do erotismo dos filmes de Warhol. A "pornografia" de Warhol não poderia ser substituída por um olhar in loco da cena, pois ela está em seu olhar, um olhar que se faz por meio da máquina e que contamina, sexualiza tudo o que vê.

Na tradição da crítica de cinema, é considerado "autor" de um filme o diretor que não apenas possui uma assinatura estilística, mas que é capaz de imprimir sua visão pessoal sobre aquilo que filma. Falar de "estilo" em Warhol, como disseram Aprà e Ungari, é falar em vão: podemos falar de um "look" maquínico e desinteressado, mas isso 
seria não ir além da superfície dos filmes. Para além da superfície, se nossa perspectiva é autorista, devemos investigar a hipótese de um olhar pessoal que se exerce por meio desse sistema. E, no caso de Warhol, parece-nos que o erotismo é a chave disso tudo.

Seguindo essa hipótese de um olhar pessoal (e não de um "olho de vidro" ausente), a própria duração dos planos em Warhol pode deixar de ser pensada como um dispositivo serialista para ganhar outros sentidos. Em alguns casos, a recusa ao corte é imbuída de um prazer sádico em obrigar os atores e modelos a permanecerem imóveis ou a darem continuidade infinita à performance diante da câmera. Em outros, ela pode se tornar até mesmo expressão de uma obsessão: obsessão escopofílica, prazer de olhar.

É o caso de Sleep. Um dos filmes mais célebres de Warhol, Sleep entrou para a história do cinema como "o filme de uma pessoa dormindo por seis horas", descrição que eventualmente assume a variação errônea de "uma pessoa dormindo em tempo real por uma noite". Este suposto filme em "tempo real" é, com efeito, um dos mais fabricados, mais decupados e montados, de Warhol. Ao longo das 5h21 de filme, alternamos entre diversas partes do corpo seminu de John Giorno: abdômen, pescoço, rosto, joelho, bunda. A experiência de Sleep, portanto, é menos aquela do "sono" do que a de alguém que olha obsessivamente para um outro dormindo. São cinco horas de observação de um corpo desacordado, respirando, por meio de enquadramentos que, longe de serem aleatórios, nos dizem algo daquele que olha, daquele que os filmou. A forma com que o filme denota o olhar se insere na longa tradição pictórica de se retratar a vigília diante do amado adormecido, uma visão ainda mais reforçada quando se sabe que Giorno e Warhol eram namorados na época.

Assim, se Sleep pode ser lido como um gesto de resistência, um ato político frente a uma sociedade produtivista que recusa o tédio e na qual o sono se faz último reduto, é apenas numa leitura exterior do filme: para afirmar esse gesto político, sequer é preciso ver de fato o filme, observar sua forma, mas apenas ler sua sinopse ou descrição. Pois dentro do filme há efetivamente isto: o corpo de John Giorno em enquadramentos que o magnificam. Na decupagem, predominam planos muito próximos, que amplificam em escala as frações do corpo ao mesmo tempo em que nos forçam a contemplá-las em sua presença imediata.

No entanto, é quando Warhol passa a se permitir zooms que seu olhar obsessivo, e à sua maneira erótico, parece se liberar. Em Chelsea Girls, durante o rolo "Hanoi Hannah and Guests", as superstars de Warhol tagarelam, improvisam, discutem, choram, enquanto a câmera passeia pela cena em zooms frequentemente em desencontro com o 
que é dito pelas personagens. Os reenquadramentos com o zoom não têm sentido dramático, ao contrário: eles desdramatizam a cena. Mas explicitam o olhar de Warhol. A câmera erra pelos rostos, isolando-os obsessivamente em close ups: fica claro que o prazer que Warhol sente, e que ele quer nos transmitir, é o prazer de olhar para aqueles rostos. Aliás, algo a se notar: a fascinação erótica de Warhol se dirige sobretudo aos rostos femininos, enquanto aos homens ele tende a se liberar para outras partes do corpo - seu olhar, portanto, tem um fundo nitidamente homossexual.

O mais importante aqui é perceber que a máquina-Warhol é uma construção. Sua simplicidade não deve ser entendida como expressão de um pragmatismo ferrenho "faço sempre o mais simples" ou algo do gênero. É preciso todo um sistema, uma complexa práxis artística, para capturar as coisas "tão simples quanto são em si mesmas". As coisas podem vir até nós, mas elas chegam suspensas, portadas por uma máquina que se dá a ver.

No limite, a práxis artística de Warhol passa pela estetização da própria vida: "I like boring things", "I don't have strong feelings for anything” etc. Pois é verdade que, com a fama, Warhol se verá cada vez mais preso numa indistinção entre artista e persona pública. O risco aqui é dar ao artista o monopólio na interpretação de sua obra. No entanto, gostaríamos de pensar na performatividade de Warhol, suas declarações, antes como uma obra de arte à parte, que mantém relações profícuas, complexas (nem sempre esclarecedoras: às vezes trata-se de obscurecer), com sua obra de fato.

Stephen Koch nota que, à medida que Warhol se torna uma celebridade, ele se torna também uma imagem: a imagem do dândi. Para Baudelaire (1996, p. 53), a beleza do dândi residia em sua impassibilidade, em sua "inabalável resolução de não se emocionar". Warhol, afirma Koch (2002, p. 23), transformando a si mesmo em celebridade "se comprometeu com a 'resolução de não se emocionar' de Baudelaire um esforço para abrigar-se na placenta transparente do reino estético, retirado da violência e das emoções do tempo e do espaço do mundo".

O dândi é alguém que dissimula. Warhol, em suas entrevistas, só faz isso: dissimular com falsa inocência, negando qualquer significado em sua obra que vá além de um sentido de superfície. "Não há razão mais profunda para eu estar fazendo uma Death Series, não se trata de 'vítimas de seu tempo’; não há razão alguma para eu estar 
fazendo isso, apenas uma razão de superfície” (BERG, 1989, p. 56). A fachada construída para essa dissimulação será precisamente aquela da máquina. É por isso que é preciso ressaltar de todas as formas, por meio de muitas estratégias, um traço maquínico em suas obras. A máquina-Warhol é uma máquina de dissimulação; ela existe para esconder o artista. Mas acreditamos que há um olhar latente no interior da máquina, que será o assunto do capítulo que segue. 
CAPÍTULO 2

Corpo, superfície e erotismo 


\subsection{Um cinema do corpo}

Já dissemos anteriormente que a característica principal dos filmes de Warhol, aquilo que os distingue de sua obra mais célebre como artista plástico, é o fato de que eles são centrados em pessoas. Mas, para Warhol, filmar pessoas significa, em primeiro lugar, filmar seus corpos. Em seus filmes, sentimos sempre uma presença muito forte dos corpos dos personagens, quase como um magnetismo. Patrick De Haas (2005), não por acaso, usa a expressão "braile mental" para definir o cinema de Warhol: são filmes que transmitem uma sensação muito física e nos quais o corpo claramente constitui o foco da encenação. Mais do que isso: a relação entre a câmera e o corpo nos filmes de Warhol com frequência ganha contornos de uma verdadeira obsessão.

Como explicar essa sensação tão física, essa verdadeira pregnância do corpo nos filmes de Warhol? Acreditamos que ela tem sua raiz em dois procedimentos básicos. Primeiro, nas estratégias de composição: os corpos são dispostos em geral no centro do quadro, de maneira sempre muito frontal em relação à câmera e, frequentemente, nus. $\mathrm{O}$ segundo procedimento tem mais a ver com o "olhar" articulado por esses filmes, com o fato de que os filmes de Warhol se voltam para a exterioridade dos atores. Esses filmes parecem operar num regime de "tirania da exterioridade", recusando toda metafísica, apegando-se à superfície, à “casca" dos personagens, mais do que a um conteúdo ou a uma individualidade profunda deles.

Falemos, primeiro, das estratégias de composição. Em Warhol, a câmera atua ao mesmo tempo isolando e fixando os corpos no interior de um dispositivo cênico rigoroso. Seus filmes, via de regra, se passam em internas, e os cenários possuem pouca ou nenhuma importância, sendo muitas vezes obscurecidos pela iluminação. A figura se destaca e se sobrepõe ao fundo: todo o foco se volta para a presença humana. Os corpos dos "atores" geralmente são posicionados em primeiro plano, muito próximos à câmera, de forma que praticamente não é possível falar em profundidade de campo em Warhol. Cria-se, assim, uma forte sensação de contiguidade entre a câmera e os "atores", que é em boa parte responsável pela pregnância corpórea dos filmes.

Isso é evidente nos filmes da "fase silenciosa", em que um único personagem posicionado muito próximo à câmera realizava um gesto isolado (comer, beijar ou simplesmente posar, como nos Screen Tests). Nos filmes sonoros essa estrutura elementar se complexifica, mas o próprio dispositivo pouco muda: os corpos se multiplicam, mas a cena permanece única, concebida como unidade isolada, restrita, apresentada quase 
sempre de maneira muito frontal em relação à câmera. A figura humana segue como o centro da encenação, sendo destacada seja por sua posição no espaço, seja por meio de zooms (Chelsea Girls, Poor Little Rich Girl).

Os filmes da "segunda fase", como Vinyl, Beauty \#2 e Kitchen, possuem o espaço cênico à maneira de um cubo que isola e circunscreve as performances dos atores. Algo semelhante se dá em Chelsea Girls, em que cada "plano-rolo"" corresponde, conceitualmente, a um dos quartos do famoso Hotel Chelsea, algo reforçado pela dupla projeção, que dá a ideia de dois eventos simultâneos se passando em espaços contíguos. ${ }^{2}$ A câmera aqui permanece no tripé do início ao fim de cada rolo, fixando e isolando um espaço (um "quarto"), enquanto o uso constante de zooms reforça ainda mais o foco no corpo dos atores, obrigando o espectador a contemplá-los de forma direta e obsessiva. Em Vinyl, adaptação de Warhol para o livro Laranja mecânica, de Anthony Bugess, um efeito curioso resulta desta relação entre espaço cênico, figura e fundo. O espaço aqui é montado inicialmente à maneira de um palco, permanecendo quase o mesmo do início ao fim do filme: no entanto, à medida que os personagens e suas performances se amontoam e se acumulam no interior daquele cubo cênico, temos a impressão de que é o próprio espaço que vai sendo abolido, dando lugar à pura presença imediata dos corpos.

Eventualmente, esse cubo cênico - que isola, circunscreve e destaca a figura ganha os contornos claustrofóbicos de uma prisão. É o caso de Beauty \#2 e dos Screen Tests, filmes que se baseiam em boa parte no desconforto de seus modelos diante da câmera. Com o enquadramento fixo do início ao fim, esses filmes operam, como vimos, menos nos termos de uma mise-en-scène do que de um dispositivo em que o espaço é um dado a priori, anterior à cena: a câmera isola uma porção limitada de espaço na qual os corpos são depositados e precisam permanecer ali, com seus movimentos limitados, obedecendo à rígida dinâmica daquele dispositivo. Resulta disso a franca sensação de tortura desses filmes, que manifestam ainda mais claramente uma certa perversidade presente na obra cinematográfica de Warhol como um todo.

Beauty \#2 e My Hustler (1965) se destacam pela precisão e pela meticulosidade com que inscrevem os corpos em seus enquadramentos. Nesses filmes, o dispositivo cênico é construído de tal forma que nosso olhar sempre recai sobre os corpos

\footnotetext{
${ }^{1}$ Por plano-rolo nos referimos ao procedimento característico dos filmes de Warhol em que a duração dos planos equivale à duração dos próprios rolos de película. Tomei a expressão emprestada de Benjamin Leon, no artigo "Composer la lumière para le corporel dans le cinema de Andy Warhol".

${ }^{2}$ Ainda que nem todas as sequências tenham sido rodadas no célebre hotel.
} 
objetificados, respectivamente, de Edie Sedgwick e Paul America. Em Beauty \#2, o ponto de vista geométrico da encenação é reiterado já nos créditos iniciais, que anunciam em voz alta Edie como "o primeiro ângulo do triângulo". De fato, a câmera (sempre fixa) é posicionada de forma que o corpo seminu de Edie, deitada sobre a cama, ocupe sempre o centro do quadro, uma centralidade que é reforçada ainda mais pela iluminação altamente contrastada, destacando-a do ambiente por meio da luz refletida em sua pele nua. A iluminação será utilizada por Warhol como forma de destacar a figura humana em vários filmes, sobretudo naqueles em preto e branco, ${ }^{3}$ e veremos adiante como isso se liga a uma verdadeira obsessão pela superfície da pele dessas figuras.

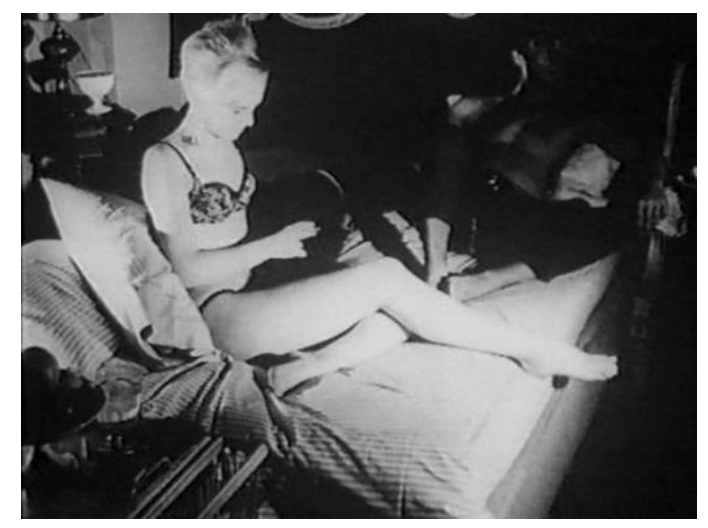

Beauty \#2 (Andy Warhol, 1965)

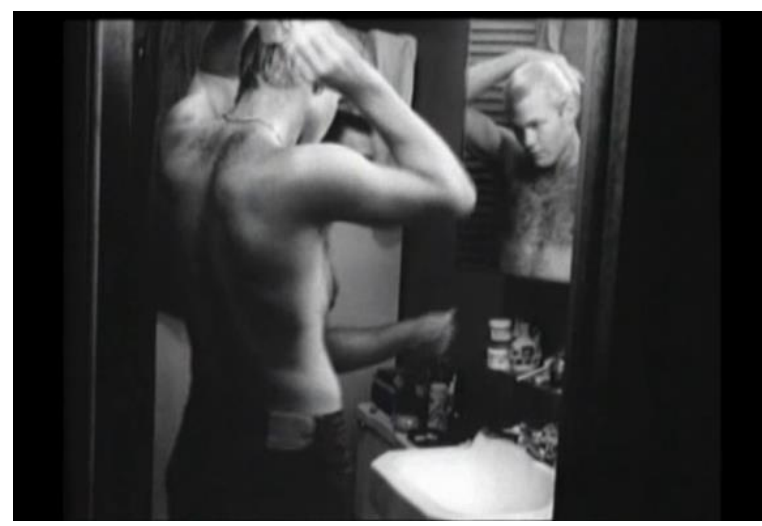

My Hustler (Andy Warhol, 1965)

My Hustler é composto de dois "planos-rolos", cada um com cerca de meia-hora. No primeiro, Warhol estabelece um dispositivo bastante complicado em que a câmera alterna entre os personagens que conversam na varanda e zooms em direção ao corpo "mudo" de Paul America na praia. No segundo (ver foto acima), a câmera é posicionada rigidamente à porta do banheiro: um espaço exíguo no qual Paul America e Joseph Campbell, ambos sem camisa, se espremem, realizando rituais banais como pentear o cabelo e fazer a barba, enquanto conversam. Neste "cubo cênico" rígido, a exiguidade espacial faz com que nosso olhar invariavelmente recaia sobre o torso nu dos personagens. A própria geometria do enquadramento nos força a olhar para o corpo.

\footnotetext{
${ }^{3}$ É preciso não deixar de mencionar que os atores de Warhol possuem, em sua esmagadora maioria, a pele branca. Um tal tipo de crítica cultural, no entanto, foge aos nossos propósitos.
} 
Falamos em nudez e, de fato, nos filmes de Warhol ela constitui uma das principais iscas que atraem o olhar do espectador para o corpo. Pode-se pensar que se trata de um artifício barato, argumento este usado por muitos para desqualificar os filmes da fase tardia de Warhol como mera incursão comercial no nicho de sexplotation. No entanto, a nudez mais ou menos explícita está presente em todas as fases do cinema de Warhol. Mesmo desconsiderando um filme como Couch (1964), observamos aqui que algumas de suas melhores obras - como Sleep, Beauty \#2, My Hustler — tiram boa parte

de sua intensidade da presença de partes do corpo despidas de seus personagens. É impossível ignorar o erotismo latente nesses filmes.

No entanto, na obra de Warhol, a nudez parece possuir ainda uma função anterior, que precede o erotismo. Pois o que a nudez nos proporciona é precisamente um personagem despojado dos códigos do teatro social, despido de figurinos ou qualquer artifício que desvie nosso olhar de sua presença corpórea mais imediata. Um corpo reduzido tão somente a seus atributos físicos. É esse corpo despojado, literal, tornado apenas materialidade, que interessa a Warhol. Um corpo que gostaríamos de chamar de puro.

Mas esse corpo puro não é destituído apenas de seus códigos exteriores, de suas roupas e figurinos. Ele é despojado também internamente de uma identidade, de um "eu" interior profundo. E aqui entra em jogo o segundo procedimento responsável pela sensação muito física dos filmes de Warhol. Pois, primeiro, o corpo é centralizado, disposto de forma frontal em relação à câmera, em geral permanecendo muito próximo a ela e iluminado em alto contraste. Mas a questão aqui não é simplesmente destacar visualmente o corpo. A radicalidade do cinema de Warhol está em transformar tudo o que é colocado diante de sua câmera em mera superfície, em reduzir todos os corpos dos personagens à pura exterioridade.

\section{Opacidade e esvaziamento}

Mas como chegar a esse corpo puro? Como chegar à exterioridade, à pura superfície? Filmar a exterioridade das pessoas não é o mesmo que simplesmente apontar a câmera para elas. As coisas não são tão simples assim. Um cinema "físico" ou "da exterioridade" não nasce por geração espontânea. É preciso um processo. Não devemos confundir a simplicidade e a aparência rudimentar dos filmes de Warhol com frouxidão de estilo e ausência de rigor (lembremos de Shaviro: "a banalidade e a autoevidência das superfícies 
de Warhol" são efeitos "cuidadosa e deliberadamente" produzidos [2015, p. 238]). Como cineasta, Warhol chega até essa exterioridade, valendo-se de alguns artifícios.

Diríamos que há, no cinema em geral, pelo menos duas formas de se chegar à exterioridade pura: pela via da opacidade ou pela via do esvaziamento. No primeiro caso, o corpo esconde sua profundidade, seu eu interior, impondo uma superfície opaca. No segundo, ele nos deixa ver o que há dentro, mas apenas para constatarmos que não há nada, que ele é apenas um corpo - banal, sem identidade, sem profundidade. A segunda via é mais radical, e acreditamos que é ela que predomina nos filmes de Warhol.

Muito embora se possa argumentar que há também efeitos de opacidade. Em My Hustler, o personagem de Paul America ressoa como uma superfície impenetrável enquanto todos os olhares do filme (inclusive aquele da câmera) se voltam para seu corpo. O efeito de opacidade aqui é fruto tanto de seu mutismo na primeira cena, em que o personagem na praia é observado à distância pelos que estão na varanda, quanto de sua imperturbabilidade em relação a toda a trama e todos os desejos a seu redor.

Vê-se, portanto, que opacidade e esvaziamento são produtos das articulações de um filme. São formas de compor, apresentar e agenciar as imagens, e devem ser entendidas como fruto de uma complexa dinâmica interna das obras que envolve câmera, cena, personagens, narrativa, entre outros fatores. No caso de My Hustler, a opacidade não é resultado apenas de uma "inexpressão", de uma "falta", um mutismo (Paul America inclusive chega a falar algumas palavras na segunda metade do filme), mas da impassibilidade do personagem em relação aos desejos e afetos que o cercam. Já os filmes silenciosos de Warhol, por outro lado, parecem operar por meio de um processo de esvaziamento, como argumentaremos mais à frente. Por fim, é importante frisar que opacidade e esvaziamento não são autoexcludentes, e que eles podem perfeitamente coexistir numa mesma obra.

Saindo da opacidade, como chegar ao corpo puro por meio do esvaziamento? Será preciso retirar deste corpo todo o conteúdo para que reste apenas a casca, a superfície, o corpo literal. Se esse corpo fala, será preciso reduzi-lo a um amontoado de afetações, tornar o que ele diz inócuo. Mas, falante ou não, será preciso sobretudo esgotá-lo, saturálo, desarticulá-lo até que seus gestos se tornem um puro maneirismo sem conteúdo.

Por acreditamos que o corpo esvaziado predomina em Warhol, tendemos a concordar com Steven Shaviro quando ele afirma que

todos os filmes de Warhol, dos mais rigorosamente estruturais e conceituais (Sleep, Kiss, Empire) aos mais relaxados, preenchidos com 
conteúdo e ostensivamente comerciais (incluindo especificamente, obras como Flesh, Trash e Heat, feitas, em nome de Warhol, por Paul Morrissey), são marcados pelo literalismo com o qual eles esvaziam todos os outros significados e conteúdos para, então, capturar, gravar e mostrar a presença pura, estúpida, inerte dos corpos. Talvez somente Robert Bresson tenha ido tão longe quanto Warhol ao esvaziar a representação e igualar diretamente a apresentação cinemática com a estupidez e a passividade da carne. (SHAVIRO, 2015, p. 242; grifo nosso)

"Capturar, gravar e mostrar a presença pura, estúpida, inerte dos corpos": é precisamente esta presença que chamamos aqui de corpo puro. Mas o texto de Shaviro traz ainda outra palavra importante: literalismo. Os filmes de Warhol são radicalmente literais, são documentários sobre a própria presença das coisas diante da câmera — o corpo é "puro" porque é literal, porque é pura denotação, porque perdeu a capacidade de significar, de comunicar qualquer coisa a não ser a própria presença imanente. Talvez derive justamente daí a impressão de Mekas de que esses filmes mostram as coisas "como elas são em si mesmas" - “o comer enquanto comer, o dormir enquanto dormir, o cortar o cabelo enquanto cortar o cabelo". Esvaziadas de todo significado, elas restam apenas como presença obtusa, dotadas apenas de seus atributos físicos: corpo, pele, exterioridade. Mas como esse esvaziamento ocorre na prática?

\section{Tempo e tautologia}

Quanto mais você olha exatamente a mesma coisa, mais o sentido desaparece e melhor e mais vazio você se sente. ${ }^{4}$

Andy Warhol

Entre os recursos empregados por Warhol para esvaziar os corpos que filma, nenhum deles tem papel mais preponderante do que o tempo. Muito além de uma marca estilística ou de uma provocação conceitual (como muito se supôs), o tempo tem uma função prática, operacional no cinema de Warhol. Aqui, um duplo mecanismo se impõe novamente. Primeiro, como vimos, a câmera isola o "assunto" do filme: esse assunto pode ser uma pessoa, um corpo, um gesto ou uma situação. Em seguida, esses corpos, gestos ou situações são expostos à câmera por muito mais tempo do que seria necessário para que o espectador pudesse "lê-los". O tempo satura a imagem, esgota todas as suas

\footnotetext{
${ }^{4}$ WARHOL, 2013, p. 67.
} 
virtualidades, todos os significados e leituras possíveis deste signo, até o ponto em que não resta nada além da pura presença de um significante esvaziado.

Cabe aqui reforçar o fato de que os filmes de Warhol se voltam para um "conteúdo mínimo": para além de uma estética redutora, eles em geral também são centrados no registro de um único "motivo". Nos primeiros filmes, esse motivo normalmente é um corpo estático (os Screen Tests, Empire) ou realizando um gesto (comendo em Eat, beijando em Kiss, dormindo/respirando em Sleep). Nos filmes sonoros, os corpos se multiplicam, mas via de regra a cena é única. Filmes como Beauty \#2, Kitchen (1965) e Vinyl têm em comum o espaço cênico isolado e exíguo, que permanece o mesmo do início ao fim dos filmes. Em Chelsea Girls (1966) há várias cenas, mas elas não se comunicam entre si; elas se fecham em si mesmas. Esse isolamento da cena é literal: pois cada "cena" equivale a um rolo de projeção, de maneira que a cena é concebida como bloco de espaçotempo fechado, fisicamente apartado dos outros na unidade "rolo". Nos ditos filmes "narrativos" de Warhol, esse isolamento das cenas, que se encerram em si mesmas tanto espacialmente quando dramaticamente, será a regra.

É esse isolamento (de um corpo, de um gesto ou de uma situação) que faz com que os filmes operem por meio de uma tautologia. Todo o rigor da produção de Warhol reside aí, para além de sua aparência frouxa e caótica. Ao longo das cinco horas de Sleep, os pontos de vista da câmera variam, mas apenas para retornar sempre ao mesmo corpo - um corpo que nunca abandonamos, do qual nunca saímos. Como também nunca saímos dos "quartos" de Chelsea Girls e do cubo cênico rigoroso que encerra as performances de Beauty \#2, Vinyl e Kitchen. Se o gênero do retrato se revelará uma das principais especialidades de Warhol no cinema, é porque ele representa justamente este isolamento espacial de um corpo - e, no caso de um retrato fílmico, sua exposição à duração do tempo.

Benjamin Buchloh observa que as telas de Warhol operavam por uma dupla estratégia de "singularização e repetição serial" (2001, p. 22). A imagem (de uma garrafa de Coca-Cola, de um telefone, de um ícone pop) era centralizada, isolada e posteriormente repetida. Essa estratégia permitia a Warhol eliminar da tela "os balanços da composição relacional" (ibid.).

A imagem-design de Warhol (seja em sua estrutura singular emblemática, seja na repetição múltipla de uma única unidade) extingue todos os recursos poéticos e proíbe a livre associação de elementos pictóricos pelo espectador, apresentando ao invés disso uma 
experiência de confronto pela restrição. De maneira muito literal, as imagens singularizadas de Warhol se tornavam herméticas: isoladas de todas as outras imagens ou abafadas por sua própria repetição, elas não podem mais gerar "sentido" e "narração" à maneira das assemblages sintáticas de Rauschenberg. (BUCHLOH, 2001, p. 22)

Buchloh fala aqui de uma estratégia de composição: a centralização e o isolamento da imagem como forma de interromper toda propriedade discursiva ou expressiva em prol de uma afirmatividade tautológica. ${ }^{5}$ Este isolamento sintático não deixa de estar presente, como vimos, também nos filmes. Ele também nos permite entender de maneira mais profunda as conexões entre a obra de Warhol como artista plástico e seus filmes. Nos quadros de Warhol, as latas de sopa Campbell ou a imagem de Marilyn eram arrancadas de seu contexto original de circulação (respectivamente, o mercado de bens de consumo ou o cinema comercial), destituídas de sua função de mercadoria (Marilyn em si pode não ser uma mercadoria, mas sua imagem o é) e transpostas apenas em suas qualidades superficiais, em sua embalagem, seus contornos — sendo isolados no espaço da tela "à maneira do ready-made duchampiano". Essa descontextualização pelo isolamento, e a fruição tautológica que deriva daí, também está presente de alguma forma nos filmes.

Eat não é exatamente um filme sobre um homem comendo: é o gesto de comer destituído de sua função orgânica primordial, transformado em compulsão vazia e tornado aberrante pela repetição no tempo. Por muito tempo se associou os filmes de Warhol a um "tempo real", no sentido de um "tempo cotidiano": é mais ou menos isso o que faz Deleuze quando afirma que os filmes de Warhol se voltam para o "corpo cotidiano" (2005, p. 230). Da forma como entendemos, no entanto, o tempo cotidiano é o tempo justo, o tempo das coisas. Ele pressupõe um acordo orgânico entre a temporalidade e os eventos mostrados. Mas esse acordo em Warhol é substituído por uma relação aberrante com o tempo. Em Eat, é Robert Indiana que tem de adaptar o ato de comer ao tempo do filme, e não o contrário. Assim, o tempo atua destituindo as coisas do tempo que lhes seria natural, o tempo demandado pelos eventos. Pois Warhol dá aos eventos um tempo muito maior do que aquele exigido por eles. $\mathrm{O}$ tempo transpassa e ultrapassa o evento, abrindo uma fenda, um vazio no interior do signo. O "cotidiano" (o

\footnotetext{
${ }^{5}$ Buchloh (2001, p. 11) ainda: “Aparentemente então no fim dos anos 1950, Warhol, tanto comercialmente competente quanto artisticamente sagaz, estava singularmente preparado performatizar a transformação historicamente necessária do papel do artista no contexto americano pós-II Guerra Mundial, $a$ transformação de uma prática estética da negação transcendental para aquela da afirmação tautológica, melhor articulada no famoso dito de John Cage: 'Nossa poesia é agora a consciência de que nada possuímos. Qualquer coisa de agora em diante será um prazer (uma vez que não a possuímos...)”.' Grifo nosso.
} 
comer, o dormir, o beijar) é reencontrado ao fim desse processo, mas modificado. Não se trata de um tempo real cotidiano puro e simples, mas de uma operação.

Sleep e Empire são provavelmente os filmes que mais se aproximam de um "tempo real": mas não esqueçamos que a duração aqui é manipulada pela projeção a 16 fps. Sleep é todo constituído de trucagens, planos que se repetem em loop. Pode-se ler o filme como um "fragmento de uma noite": mas essa leitura conceitual contempla pouco o que há de mais essencial no filme, isto é, suas articulações internas entre a câmera, o olhar do filme e o corpo, articulações essas que se dão também no tempo, que se valem portanto deste tempo prolongado da experiência para operar. No fundo, estamos fortemente inclinados a dizer que Sleep não é "sobre o sono", mas sobre alguém que observa esse corpo adormecido de diversos pontos de vista. Em outras palavras, ler o tempo do filme como um tempo da obsessão e da fascinação erótica, e não como um tempo do cotidiano.

Nos filmes sonoros, o tempo atua desconstruindo a performance, dada a impossibilidade de esta permanecer "de pé" por tanto tempo, sem ser "socorrida" pelo corte, posto que a câmera de Warhol é impassível. Num momento de Chelsea Girls, Ondine, que contracenava com Rona Page, se descontrola completamente e, entre vários insultos, afirma que "ela estragou o set todo". "Estragar tudo" é deixar o malabarismo da performance vir ao chão. Algo semelhante ocorre com a impossibilidade de os figurantes dos Screen Tests manterem a pose estática pelos três ou quatro minutos de duração do rolo.

O efeito de banalidade que os filmes de Warhol possuem deriva do isolamento de seus motivos figurativos. Ele retira os gestos e os atores de seu contexto "natural" (o filme de ficção, ou o fluxo da vida real) para atirá-los num deserto de tempo e película, expostos ao tempo. Uma vez isolados e saturados pelo tempo, esses gestos, corpos e situações não conseguem comunicar mais nada, a não ser sua própria presença. Pois o isolamento nos interdita conexões, tanto entre eles e uma narrativa hipotética, quanto em relação ao próprio mundo exterior. Paralelamente a isso, o tempo vai dissipando os potenciais significados da imagem. Primeiro pensávamos que a imagem significava uma coisa, depois outra, depois... nada. Nos contentamos em entreter uma relação puramente física com a imagem. Comentando sua fascinação pelas estrelas do cinema, o próprio Warhol faz um comentário muito preciso nesse sentido: 
Realizei meus primeiros filmes utilizando apenas um ator fazendo a mesma coisa por várias horas: comendo ou dormindo ou fumando. Fiz isso porque as pessoas normalmente vão ao cinema apenas para ver a estrela do filme, para devorá-la, então aqui está uma chance de olhar apenas para esta estrela por tanto tempo quanto se quiser, não importa o que ela faça, e devorá-la o tanto que você quiser. Também era mais fácil de fazer. (BERG, 1989, pp. 56-57)

Assistindo aos filmes de Warhol, nunca acessamos uma dimensão mais profunda de Edie Sedgwick. Mesmo contemplando-a por horas e horas a fio, os filmes nunca nos dão a ver algo além da superfície - uma personalidade, uma individualidade profunda. Permanecemos sempre no terreno da frivolidade, contemplando, quando muito, suas poses e afetações. É nesse sentido que os filmes de Warhol, e em particular os "filmesretrato", como Poor Little Rich Girl e os Screen Tests, são documentários sobre a própria presença imanente dos corpos diante da câmera - uma presença isolada que é em si e para si mesma, jamais se prolongando em outra coisa.

\section{Cinema materialista}

David Ehrenstein: Você gostaria de fazer um filme com Carroll Baker? Andy Warhol: Uh... não.

D.E.: Por que não?

A.W.: Uh... Ela tem muita habilidade de interpretação... para mim. D.E.: Pessoas com habilidade de interpretação não são o tipo que você precisa? A.W.: Não, eu quero pessoas reais. ${ }^{6}$

Warhol nunca desejou ou, pelo menos, nunca se esforçou para fazer um cinema mais tradicional e narrativo. Quando perguntado por Ronald Tavel, roteirista de alguns de seus filmes, se queria uma "história", uma "trama", ele responde: "Não, sem trama, mas um incidente" (KOCH, 2002, p. 63). Essa resposta deixa claro que o aspecto não narrativo do cinema de Warhol era, portanto, deliberado e consciente. Um "incidente" é uma situação que pode se desdobrar, mas que não chega a se prolongar numa trama. Ele permanece, assim, como algo essencialmente estático, que se encerra em si mesmo.

Mais decisivamente ainda, nenhum dos filmes de Warhol tem apreço pela constituição de um universo diegético ilusionista. Isso é relevante, sobretudo, para seus filmes roteirizados. Em Kitchen, por exemplo, havia um roteiro, de autoria de Tavel,

\footnotetext{
${ }^{6}$ Entrevista publicada na Film Culture no ${ }^{40}$, primavera de 1966, p. 41.
} 
seguido pelos atores, mas o ilusionismo é constantemente minado pela irrupção de elementos "extradiegéticos": um fotógrafo interrompe com frequência a cena doméstica (remetendo à prática do still, de fotografar as cenas e as vedetes para posterior promoção do filme); os atores volta e meia olham para a câmera e têm suas falas "sopradas" por alguém dentro ou fora de quadro; a câmera que permanece ligada mesmo após a "encenação" ter terminado (ou antes de ela recomeçar no início do segundo rolo). Todos esses "acidentes" são incorporados ao filme. Assim, o roteiro inicial se torna um "prétexto" (GIDAL, 1989, p. 53), um guia para as cenas, mas cujo tecido ficcional e os papéis por ele determinados não obliteram o processo de fabricação da cena, não chegam a realizar plenamente a ilusão.

É preciso notar, contudo, que os próprios roteiros de Ronald Tavel já operavam numa chave não ilusionista. Seria impreciso, portanto, caracterizar a relação WarholTavel nos termos de uma desconstrução unilateral por Warhol dos roteiros escritos por Tavel. O que houve foi uma parceria produtiva. Sobre Kitchen, Tavel afirma:

Trabalhei para me livrar dos personagens. Andy havia dito: "Livre-se da trama". Claro, Samuel Beckett havia feito isso nos anos 1950, mas ele mantivera os personagens. Então pensei que o que eu poderia introduzir era descartar os personagens. É por isso que os nomes dos personagens de Kitchen são intercambiáveis. Todos têm o mesmo nome, então ninguém sabe quem é quem. (TAVEL apud MURPHY, 2012, p. 81)

Kitchen parte de um ambiente familiar doméstico (um casal na cozinha) para realizar ali uma espécie de psicodrama em que os personagens constantemente se perdem em monólogos alienados e obsessivos. No filme, os dois casais possuem nomes sonoramente idênticos, porém invertidos: o casal principal é formado por Jo (Edie Sedgwick) e Mikey (Roger Trudeau), enquanto o casal de "amigos" responde por Joe (Donald Lyons) e Mikie (Elektrah). Assim, o filme joga constantemente com o caráter ambíguo da identidade e dos papéis sexuais dos personagens. Essa estrutura deliberadamente dúbia do roteiro, somada às performances inconsistentes, cria uma constante indeterminação de papéis, que "são constantemente assumidos ou descartados [...] segundo sua vontade, seus caprichos [dos atores]" (GIDAL, 1989, p. 58). O que Warhol dispensa é a unidade orgânica do personagem que une, numa comunhão metafísica, ator e papel, corpo e texto. Estes ainda estão ligados, mas sobre o mesmo plano, o plano material — não são mais personagens, mas corpos-palavras. 
É isso que leva Peter Gidal a afirmar que os filmes de Warhol promovem um engajamento materialista com o espectador. Para Gidal, os filmes Warhol não apenas rompem a encenação ilusionista e o tecido diegético, mas encarnam, em sua indeterminabilidade total, um processo maior de recusa à metáfora e à produção de significado. Na visão materialista, a metáfora e o significado, uma relação de interpretação com o filme, devem ser recusados porque estão além do filme-comoprocesso: elas são a mais-valia desse processo, algo que o espectador retém e com que, no limite, mantém uma relação fetichista. Segundo Gidal:

Pouco resta, em Kitchen, quando o processo chega ao fim, quando o filme termina [...]. O esvaziamento dos significantes potentes, da significação, o processo cinemático no qual "pouco resta" é um engajamento materialista com o processo de produção. Aqui, o material é esgotado, processado, no lugar de reter uma existência fetichizada que precisa ser mantida para o consumo constantemente repetido (GIDAL, 1989, pp. 54-55).

Como fica claro, a visão de Gidal tem um cunho essencialmente ético e político. Nessa perspectiva, Warhol seria antifetichista, pois esvazia os significantes: as imagens são consumidas na sua própria duração e nada resta depois. Para nós, no entanto, dizer que os filmes de Warhol são antifetichistas seria ignorar muitas nuances no interior deles. Entretanto, a ideia de um "funcionamento materialista" nos interessa porque deixa entrever o essencial do cinema warholiano: seu literalismo, uma imagem que interessa em si e por si mesma, sem ecoar significados, o filme como registro sobre a película e, no “interior" dessa película, os corpos puros, literais, esvaziados de identidade, que não comunicam nada além de sua própria presença e empreendem ações meramente físicas: comer, beijar, dormir, falar, posar.

\section{Performance e presença}

Num trecho de Popismo, Warhol fala sobre a relação entre seus filmes e as superstars que os estrelavam:

Todo mundo seguiu em frente, fazendo o que sempre fizeram - ser eles mesmos (ou realizar uma de suas rotinas, o que em geral era a mesma coisa) diante da câmera. [...] Suas vidas se tornaram parte dos meus filmes e, claro, os filmes tornaram-se parte de suas vidas; eles se envolviam tanto com os filmes que você não conseguia separar direito os dois, você não podia ver a diferença - e, às vezes, nem eles podiam. (WARHOL apud SHAVIRO, 2015, p. 253) 
“Ser eles mesmos". É preciso não se iludir: as declarações de Warhol, como seus quadros, possuem sempre esse ar de verdade inocente e banal que, no entanto, mascara algo mais complexo. Pois o que mais se fazia na Factory - e o que Warhol fez como ninguém em sua vida pública (e mesmo privada) - era interpretar. Interpretava-se tanto na vida quanto nos filmes, e é com essa indistinção em mente que a citação de Warhol deve ser lida.

Longe de serem simples registros passivos da fauna de indivíduos que frequentava a Factory, os filmes de Warhol são estudos minuciosos sobre o ato de performar. Entendemos performance aqui no sentido amplo de projetar uma imagem de si, uma persona. O termo persona orginalmente quer dizer máscara, e designa tanto o personagem encarnado por um ator de teatro quanto, mais amplamente, os diversos papéis que assumimos em diversas circunstâncias sociais. Persona e performance, embora não sejam a mesma coisa, estão conectadas pelo fato de ambas serem relacionais: elas se dão na interação com o mundo exterior, se dão para o outro. Segundo Richard Schechner, "performances existem apenas como ações, interações e relacionamentos" (2003, p. 29). Em termos sucintos, performances são comportamentos codificados, que o autor denomina "comportamentos restaurados": "comportamentos marcados, emoldurados ou acentuados, separados do simples viver" (p. 34).

Por seu caráter relacional, a performance implica, ainda segundo Schechner, num observador: performar é "mostrar-se fazendo" (p. 26). Se a performance, para existir, precisa ser vista, gostaríamos de inverter essa proposição e perguntar: ser visto implica em performar? É possível sermos vistos sem performarmos? Poucas experiências são mais impactantes do que a de "ser visto", e isso pode ser facilmente ilustrado com uma experiência comum, pela qual todos já passamos: quando, em meio a um estado autoabsorto, repentinamente percebemos (ou supomos) estarmos sendo observados por alguém. A reação, mental e corporal, é imediata.

Em termos profundos, os filmes de Warhol lidam justamente com esse "ser visto" e as variadas respostas que essa experiência suscita. Mas essa "experiência", nos filmes, se dá em condições particulares. Ser visto e consequentemente performar fazem parte, é claro, do teatro social do dia a dia. Mas em Warhol esse "ser visto" é submetido a um laboratório: ele é isolado do fluxo do mundo e acrescido ainda de um outro elemento peculiar, a câmera. A câmera engendra um outro nível — ou talvez uma outra natureza — de performance, pois o indivíduo agora sabe que não apenas é visto, como também é 
gravado: que sua imagem ficará para a posterioridade, que é preciso, portanto, ter muito cuidado com o que se faz. E no entanto assim alguma coisa será feita, pois a consciência de ser observado, por uma câmera ou por outra pessoa, implica necessariamente numa reação - que pode ser absolutamente estática, mas que ainda assim é uma reação. A câmera em Warhol, portanto, afeta as situações e os indivíduos filmados, e isso já é o suficiente para negar as palavras do próprio Warhol. Como afirma David James:

A câmera é o analista silencioso que abandona o sujeito à necessidade de sua autoprojeção fantasmática [...] sozinho na ansiedade causada por saber que está sendo observado, mas tendo o acesso negado aos resultados dessa observação, o sujeito precisa construir a si mesmo em espelhos mentais de sua autoimagem e sua coleção de fotografias anteriores. (JAMES, 1989, p. 139)

Mencionamos no primeiro capítulo a veia retratista da produção fílmica de Warhol: muitos desses filmes se estruturam em função das personalidades mostradas, e a presença dos indivíduos diante da câmera tem primazia sobre o resto (narrativa, espaço, ação). Quase todo o conteúdo ficcional é dispensado, dissolvido em gestos banais realizados de maneira isolada, circular, gestos que sempre retornam a si mesmos, numa tautologia que faz com que os filmes tendam à estaticidade e à inação. Essa estratégia é análoga, precisamente, àquela do retrato na pintura, em que a ação deve ser evitada para que não se desvie a atenção da personalidade do retratado, que constitui o motivo do quadro.

Num retrato pintado, todos os elementos (a figura, sua pose, sua postura, expressão, trajes, os objetos no entorno, o fundo) concorrem para expressar a personalidade do retratado. Tradicionalmente, esse cuidadoso processo de composição lida com uma tentativa de eternizar o indivíduo: no melhor dos mundos, o retrato fixa um eu consistente e profundo que ficará para a posterioridade. Ora, mesmo que se organizem como retratos de um ponto de vista formal, os filmes de Warhol quebram uma regra fundamental do gênero: a figura aqui é submetida ao tempo. Como congelar um "eu" consistente numa imagem que capta justamente a contingência, um "eu" fluido que muda a cada instante? Há um paradoxo aí. O cinema capta não um, mas 24 (ou 16, no caso dos primeiros filmes de Warhol) retratos por segundo: cada um é a negação do retrato anterior, num contínuo processo de construção e desconstrução do eu. Nico, inquieta, faz mil poses nos quatro minutos de seu Screen Test: lê uma revista, olha para a câmera, posa de lado, de frente, olha para fora de campo. É possível falar de um “eu profundo" por trás dessas performances? 
Essa angústia diante da câmera é justamente aquela que Barthes descreve quando, diante da câmera fotográfica, se indaga que imagem sua "vai nascer":

Vão me fazer nascer de um indivíduo antipático ou de um "sujeito distinto"? Se eu pudesse sair sobre o papel como numa tela clássica, dotado de um ar nobre, pensativo, inteligente etc.! Em suma, se eu pudesse ser "pintado" (por Ticiano) ou "desenhado" (por Clouet)! No entanto, como o que eu gostaria que fosse captado é uma textura moral fina, e não uma mímica, e como a fotografia é pouco sutil, exceto nos grandes retratistas, não sei como, do interior, agir sobre minha pele [...]. Eu queria, em suma, que minha imagem, móbil, sacudida entre mil fotos variáveis, ao sabor das situações, das idades coincidisse sempre com meu 'eu' (profundo, como é sabido). (BARTHES, 2015, pp. 18-19)

Barthes descreve o conflito entre, de um lado, a vocação à estabilidade e à perenidade do retrato, e, de outro, a captação da contingência pelo fotográfico. Entre um e outro, não há dúvidas de que os filmes de Warhol abraçam a incerteza, a indecidibilidade, sem procurar mascará-la com um verniz ficcional: pois a ficção sim pode, ao imputar consistência psicológica aos personagens, apresentar retratos estáveis e profundos. Nos filmes de Warhol o que vemos, ao contrário, é uma sucessão de poses, máscaras, performances em que não sabemos exatamente onde termina a verdade e onde começa a encenação. Ou, melhor, onde tudo é falso: pois, ao isolar e esvaziar o corpo, Warhol foca sua câmera neste limiar onde começam os tiques, a performatividade mais ou menos histriônica, os artifícios de um corpo que se expressa sem, no entanto, ter nada a expressar. Os filmes de Warhol captam esse contínuo processo de construção e reconstrução de poses artificiais por parte do corpo.

É verdade que os modelos de Warhol variam: há os hesitantes, os seguros de si, os histriônicos. No entanto, todos eles performam. O dispositivo warholiano é uma máquina da verdade que a todo o momento revela a artificialidade das nossas performances. Nossas poses, nossos subterfúgios, nosso tiques. Se há uma verdade captada pelo dispositivo, é uma verdade ausente: uma verdade que se dá entre-poses, que não chegamos a ver, mas sentimos. Uma verdade que está por trás da lágrima de Ann Buchanan, entre as hesitações de Dennis Hopper, atrás da mão de Ingrid, na impossibilidade de Lou Reed manter-se como garoto-propaganda da barra de chocolate Hershey's.

A verdade se revela nesse entre, este lapso que não conseguimos capturar com o olhar, mas que sentimos na passagem de uma pose a outra (de um falso a outro), um 
pouco à maneira da "duração" de Bergson. A verdade é fugidia: no momento em que vemos a lágrima correr pelo rosto de Ann Buchanan, ela já se foi, resta apenas o signo materializado de algo que existiu, algo que foi. Alguns modelos se esforçam para entregar a performance perfeita, vedada, a pose pura. Eles se armam (de óculos escuros). Mas o olhar clínico de Warhol fará o possível para captar, revelar essa verdade, aproximandose deles, ralentando a imagem para que possamos olhar com muito cuidado este "entre". É assim que a verdade pode se revelar nos lugares mais insignificantes, como no piscar involuntário das pálpebras de Edie Sedgwick em seu Screen Test. Às vezes é difícil precisar onde a verdade está, de onde ela vem. De todo modo, ela com certeza está naquilo que não se controla, e por isso mesmo ela se revela melhor, mais claramente, nos modelos que falham, nos hesitantes (Dennis Hopper, Nico, Ingrid), em que podemos senti-la quase como um sopro para além da falsidade das aparências.
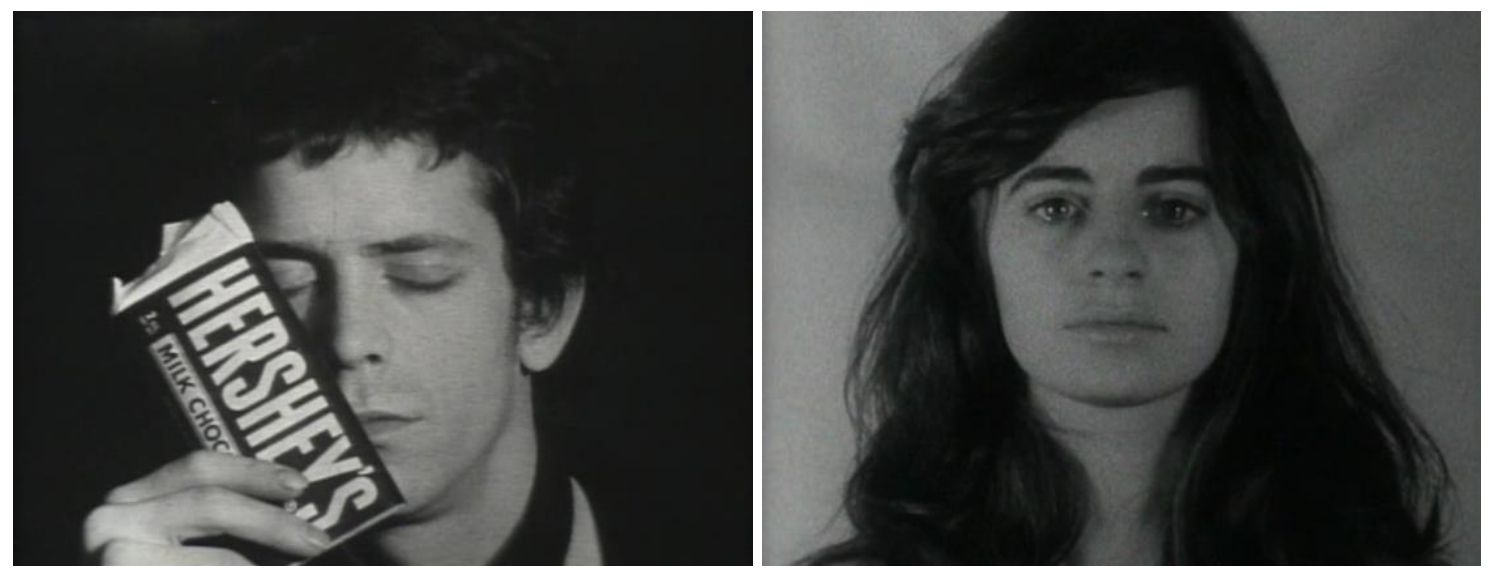

Screen Tests: a impossibilidade de Lou Reed em manter a pose sem piscar e os olhos marejados de Ann Buchanan.

Pois, se a verdade é esse entre ausente e fugidio, todo o resto é falso. A aparência é falsa. A performance é falsa, as máscaras são falsas. Warhol adorava o falso, o artificial. Quanto mais falso, melhor. "Todos os meus filmes são artificiais, mas tudo de certa forma é artificial. Não sei onde o artificial termina e o real começa. O artificial me fascina" (BERG, 1989, p. 60). Ou ainda: "Queria viver minha vida no mesmo nível do roteiro de $O s$ insaciáveis [The Carpetbaggers, Edward Dmytryk, 1963] [...] adentrar uma daquelas salas da mesma maneira que aqueles atores faziam e dizer aquelas falas de plástico" (WARHOL, 2013, p. 56). Em suas superstars, Warhol valorizava a capacidade de projetar 
uma presença. Essa presença não passava pela habilidade em interpretar um papel, pelo contrário: ela era algo intrínseco ao próprio ator. Mas presença aqui tampouco tem a ver com uma interioridade, com um conteúdo interior e profundo: as superstars de Warhol são rasos como pires. A presença é, portanto, uma qualidade que se revela na superfície. É a capacidade de projetar uma persona - carismática, magnética. A persona, como se sabe, já está na esfera do artifício. Ela não precisa prestar contas ao seu eu interior. As superstars de Warhol são aquelas que aderiam à persona, que hipotecaram seu "eu" a essa exterioridade. Pessoas para quem "ser elas mesmas" se define na exterioridade da superfície e na artificialidade da persona. É o artifício que fascina Warhol. "Quero pessoas reais": sim, mas pessoas reais capazes de projetar essa persona fascinatória. Pessoas capazes de viver nesta corda bamba entre uma interioridade magra (ou oculta) e uma presença que se expande pelo artifício. Uma prova desse interesse pelo artifício são os Screen Tests sonoros, em que as expressões nos rostos dos retratados são induzidas por vozes fora-de-campo. O prazer é observar as transformações da máscara.

Em Beauty \#2, trata-se justamente de testar a presença de Edie Sedgwick. É um teste duplo: de carisma e sexual. O filme estabelece um palco minucioso com Edie sentada sobre uma cama em roupas íntimas ocupando o centro do quadro, a luz refletindo em sua pele branca e ressaltando sua presença. Junto a ela na cama está um parceiro "em potencial", Gino Piserchio, também seminu. No entanto, diferentemente de filmes como Poor Little Rich Girl e Kitchen, em que Edie tem liberdade para exprimir seu carisma, aqui o filme é conduzido por um terceiro elemento fora-de-campo, Chuck Wein. Definitivamente não há aqui pessoas "sendo elas mesmas", mas uma presença submetida a um laboratório perverso. Wein não para de falar. Ele produz expressões em Edie, lançando iscas, confundindo-a, desmentindo-a (Wein era ex-parceiro de Edie, e joga algumas referências que ficam nebulosas para nós). Edie invariavelmente cai nas iscas, mas tenta o tempo todo recuperar a pose, entrar na conversa, responder à altura. No segundo rolo de filme começa o teste sexual. Ela e Gino trocam carícias. Mas Wein desdenha dos dois, chegando a acusar Edie de frigidez ("You can't fell anything for him”). Edie era uma das atrizes mais articuladas de Warhol. Há uma entrevista de 1965 com ela e Warhol no programa de auditório de Merv Griffin em que Warhol não diz uma palavra e Edie fica como porta-voz, falando dos filmes, fazendo piadas e interagindo com o entrevistador. ${ }^{7}$ Todo esse carisma vai abaixo quando ela é atacada: Edise se torna uma

\footnotetext{
${ }^{7}$ Atualmente é possível ver a entrevista em https://www.youtube.com/watch?v=UpE6ADR-QPI\&t=306s. Acesso em 31 de julho de 2017.
} 
série de poses vazias, frias, uma série de tiques em sua constante tentativa de re-impor sua presença. Há um contraste entre a beleza pictórica do filme, a cuidadosa composição geométrica que dispõe Edie no centro como uma estrela, e um esvaziamento dessa presença pelos ataques de Wein. A nudez e as investidas sexuais reforçam essa vulnerabilidade. O poder de sedução de Edie, seu magnetismo, é minado. Edie e Gino se tornam objetos sexuais frios, corpos puros, esvaziados.

\title{
Corpo e palavra
}

Beauty \#2 anuncia o que Adriano Aprà e Enzo Ungari (1971) denominam como uma luta, uma "rivalidade congênita" entre corpo e palavra, que se revela nos filmes sonoros de Warhol. Como se o mutismo do corpo da fase silenciosa - um mutismo que não deixa de indicar a passividade de um corpo que se oferece e se subjuga silenciosamente ao olhar da câmera - sofresse uma repentina perturbação.

\begin{abstract}
A introdução da palavra se anuncia subitamente como um fato traumático: ela é um tanto violenta, não menos do que a câmera, sua aliada em martirizar os atores. [...]. O corpo e a palavra se veem agora ocupando um papel contíguo e denunciando constantemente uma forma de rivalidade congênita, fornecendo a paródia de um nível "baixo" e um nível "elevado" bruscamente aproximados um do outro. Mesmo depois, quando [Ronald] Tavel se afastará do grupo de Warhol, permanece este sulco que separa os detentores da palavra, os que não são dela privados, e os corpos que servem de reservatório da palavra. (APRÀ, UNGARI, 1971).
\end{abstract}

A introdução do som não representa de maneira alguma uma emancipação dos corpos nos filmes de Warhol. Pelo contrário, esses corpos passam agora a ser duplamente torturados: pela câmera e pelos "detentores da palavra". Porque os corpos das vedetes de Warhol são, acima de tudo, passivos e exibicionistas. Eles jamais conseguem transcender sua condição - imposta pelos filmes - de objeto. Mesmo quando falam, esses corpos apenas tagarelam sem chegar a lugar nenhum. A fala assume neles o caráter de gesto compulsivo (como o gesto de comer em Eat) que se afoga em si mesmo e nunca chega a produzir um significado profundo.

"Palavra" aqui não é usado como mero sinônimo de "fala", portanto, mas nos termos mais amplos de uma "produção de sentido". E fica claro que, nos filmes de Warhol, os verdadeiros detentores da palavra pouco aparecem em cena: Ronald Tavel, Chuck Wein, o próprio Warhol. O que os ataques de Chuck Wein a Edie Sedgwick em 
Beauty \#2 denotam é, em última análise, esta cisão brutal entre o intelecto e o corpo puro, entre aquele que olha e aquele que é olhado, entre quem manipula e quem é manipulado. Essa dinâmica se repete nos Screen Tests sonoros, filmes de pouco mais de uma hora de duração em que Philip Fagan (Screen Test \#1) e Mario Montez (Screen Test \#2) têm suas reações induzidas diante da câmera por vozes que vêm de fora de campo. Não tivemos acesso a esses filmes, mas todos os relatos (de Aprà e Ungari, Koch e Murphy) são unânimes ao descreverem certa "violência" nas intervenções das vozes. J.J. Murphy afirma que Screen Test \#1 é "absolutamente brutal na forma como esvazia e ridiculariza Fagan" (2012, p. 58), descrevendo a direção de Tavel no Screen Test \#2 como "sádica" (ibid., p. 59). Em Beauty \#2, esse sadismo é "refinado" pela disposição meticulosa de Edie Sedgwick no centro do quadro, "imobilizada" sobre uma cama, fortemente iluminada, seminua, portanto vulnerável. No entanto, é preciso dizer que esse prazer de olhar o corpo puro, um corpo mudo, sem conteúdo, encontrava seu germe desde os Screen Tests silenciosos, muitos dos quais já carregam uma atmosfera de tortura.

No fundo, a cisão entre corpo e palavra serve a um único propósito: objetificar o corpo, torná-lo estúpido e consumível sexualmente. Nesse sentido, ela espelha uma estrutura ainda mais profunda: a divisão entre sujeito e objeto. Thomas Waugh nota que os que os corpos em Warhol se dividem basicamente em dois tipos: a queen e o hustler (ou trade). "A queen é afeminada, intensa, produzida, oral, desejosa", o hustler é “másculo, descontraído, nu, taciturno e 'hétero'. A queen olha, o trade é olhado; ela verbaliza, ele é assunto de conversas" (1996, p. 54). Para Waugh, a figura da queen em Warhol compreende não apena as drags, mas também homossexuais mais velhos (os sugar daddies) e até mesmo boa parte das mulheres. Basicamente, são todos aqueles que olham o hustler. Waugh afirma que, no limite, esse dualismo entre queen e hustler nada mais é que uma introjeção da diferença sexual no quadro representacional do cinema gay pela via da divisão sujeito-objeto.

No entanto, é importante frisar que essa “diferença” não será quitada. Isso porque, diferentemente do padrão das narrativas de casais heterossexuais, não há final feliz para a queen e o hustler. Embora interajam verbalmente, afirma Waugh, a queen e o hustler dificilmente transam, raramente consumam o desejo. Cria-se assim uma irreconciliabilidade entre sujeito e objeto que "exacerba a tensão da relação sedutora olhemas-não-toque, toque-mas-não-possua, apareça-mas-não-fale, fale-mas-não-apareça" típica do dispositivo cinematográfico (ibid., p. 57). 
Tudo isso se verifica plenamente num filme como My Hustler. O próprio título do filme não é casual. Da varanda, um sugar daddy e uma fag hag (ou maria-purpurina, gíria para moças que vivem acompanhadas de homossexuais do sexo masculino), dois estereótipos da figura da queen, observam Paul America, o hustler do título, se bronzeando na praia. Detentores da fala, eles disputam entre si quem ficará com o jovem. Eles projetam seus desejos sobre um corpo-objeto. A fala aqui se soma ao olhar dos dois (representado pelos zooms da câmera) como um elemento a mais de tensão sexual sobre o corpo mudo, "estúpido", de Paul America - a quem evidentemente não é dado nenhum direito nem ao olhar, nem à fala.

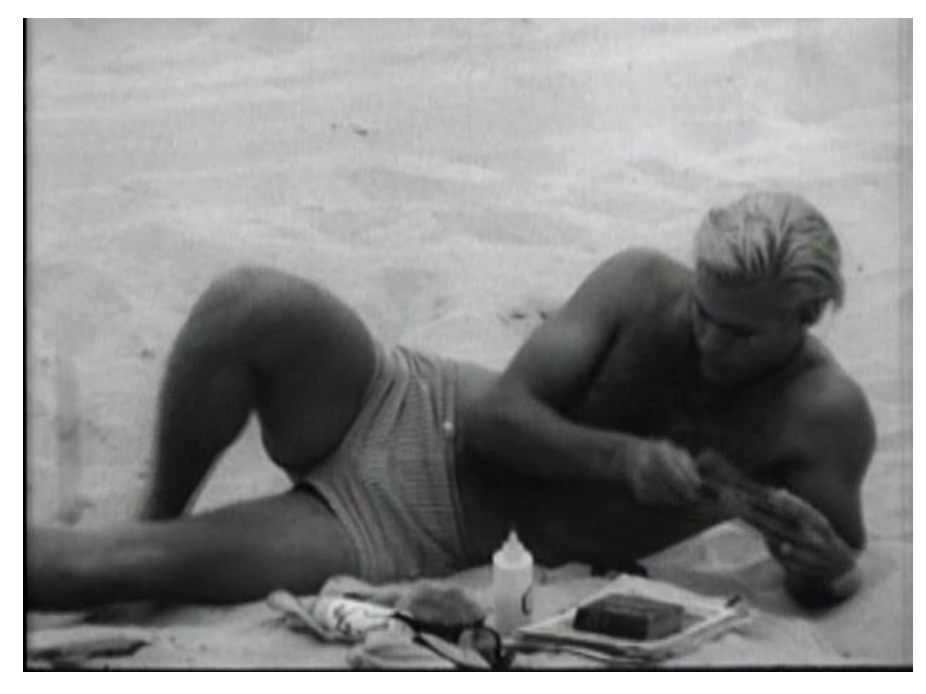

My Hustler (1965)

A rivalidade congênita entre corpo e palavra se revela ainda de outras formas na obra de Warhol: poderíamos falar da escolha nada casual de Warhol em adaptar Laranja mecânica, de Anthony Burgess. No livro de Burgess, boa parte da violência da gangue liderada por Alex, o protagonista, se volta justamente contra personagens "letrados": primeiro um homem carregando livros na saída da biblioteca, depois um escritor em sua casa com a esposa. A adaptação de Warhol, Vinyl, conta inclusive com a cena (bastante simbólica) em que Alex, aqui rebatizado de Victor, rasga páginas de livros antes de bater no primeiro homem. No futuro distópico do livro, aparentemente, é o corpo que se tornou hostil à palavra, fazendo valer sua supremacia. 
Como afirma J.J. Murphy, não é difícil perceber o que atraía Warhol em Laranja mecânica: "sua violência gráfica e sadomasoquismo, seu foco na cultura jovem, seu tema da transformação de indivíduos em máquinas, seus sobretons homossexuais" (2012, pp. 73-74). Assim, a adaptação de Warhol — que, segundo consta, pagou 3 mil dólares a Burgess pelos direitos de adaptação — será menos uma ficção científica distópica do que, precisamente, uma história do corpo.

\section{Histórias do corpo: Vinyl e I, a Man}

Vinyl, como a maior parte dos filmes realizados na parceria com Ronald Tavel, é encenado à maneira de uma peça. A câmera é sempre fixa, constituindo um espaço cênico isolado, limitado e dado a priori. Todos os atores se encontram desde o início em quadro, mesmo aqueles que só participarão de cenas posteriores. Não há cortes (exceto na mudança de rolos), e as cenas vão se acumulando uma após a outra neste "cubo cênico".

O filme inicialmente deveria se chamar Leather, ou seja, "couro", em referência ao material do traje sadomasoquista usado por Victor, o protagonista, durante a cena em que é torturado. Essa informação interessa porque deixa bastante claro o que interessa a Warhol quando decide encenar sua "adaptação" de Burgess: o profundo erotismo da violência. Aqui, trata-se de acompanhar as passagens e transformações de um corpo (de Victor, interpretado por Gerard Malanga) por diversos estágios, diversas etapas.

Inicialmente, o corpo é sublime: o filme abre com um close de Malanga, a luz refletindo em seu rosto, explorando sua beleza como se estivéssemos num Screen Test. Em seguida, veremos que esse corpo é, também, potente: vemos Malanga se exercitando, dançando e, mais à frente, achacando e torturando o "leitor de livros" (substituídos aqui por revistas). Mas esse corpo, sublime e potente no início, acabará sendo preso, torturado, abusado e dopado no andamento do filme (ver fotos). É essa a história do corpo que é encenada em Vinyl - e que de fato interessa a Warhol. Essa encenação ocorre num "palco" quase à maneira de um ritual: vemos o corpo de Malanga ser amarrado, vestido com o traje sadomasoquista, torturado com gotas de cera quente e, por fim, drogado e estuprado por Tosh Carillo, que interpreta o médico. Malanga nunca sai de quadro: ele está sempre ali, no centro, preso, sendo oferecido ao nosso olhar, e o prazer do filme sádico, de muitas maneiras - reside em observar as transformações daquele corpo exposto, suas passagens pelos diversos estágios (sublime, potente, depois preso, torturado, abusado, drogado). 
Já I, a Man (1967) é um filme realizado na parceria posterior de Warhol com Paul Morrissey. Aqui, o roteiro episódico confronta um homem (Tom Baker) com diversos estereótipos femininos: a adolescente que vive com os pais (Cynthia May); a garota de programa (Stephanie Graves); a lésbica (Valerie Solanas); a mulher casada (Bettina Coffin). Mas esse arco desenhado pelo roteiro de um potencial estudo sobre o masculino/feminino parece quase se apagar diante da matéria do filme. Ele se perde e se torna vago nas improvisações dos atores, que tagarelam sem muita objetividade. O que de fato salta aos olhos em I, a Man é a matéria dos corpos dos atores, na qual todo o resto parece se dissolver.

Isso ocorre tanto pelas improvisações inexpressivas, incapazes de projetar uma profundidade, quando pela própria decupagem, aqui consideravelmente mais agitada do que a maior parte dos filmes de Warhol. Os planos do filme ora dispõem os personagens em poses, ora retalham os corpos em planos-detalhes de partes sugestivas do corpo como pés, costas e peitorais nus (ver fotos). Como em todos os seus filmes, Warhol aqui objetifica os corpos, buscando este corpo puro que constitui a matéria mais profunda de seu cinema. 

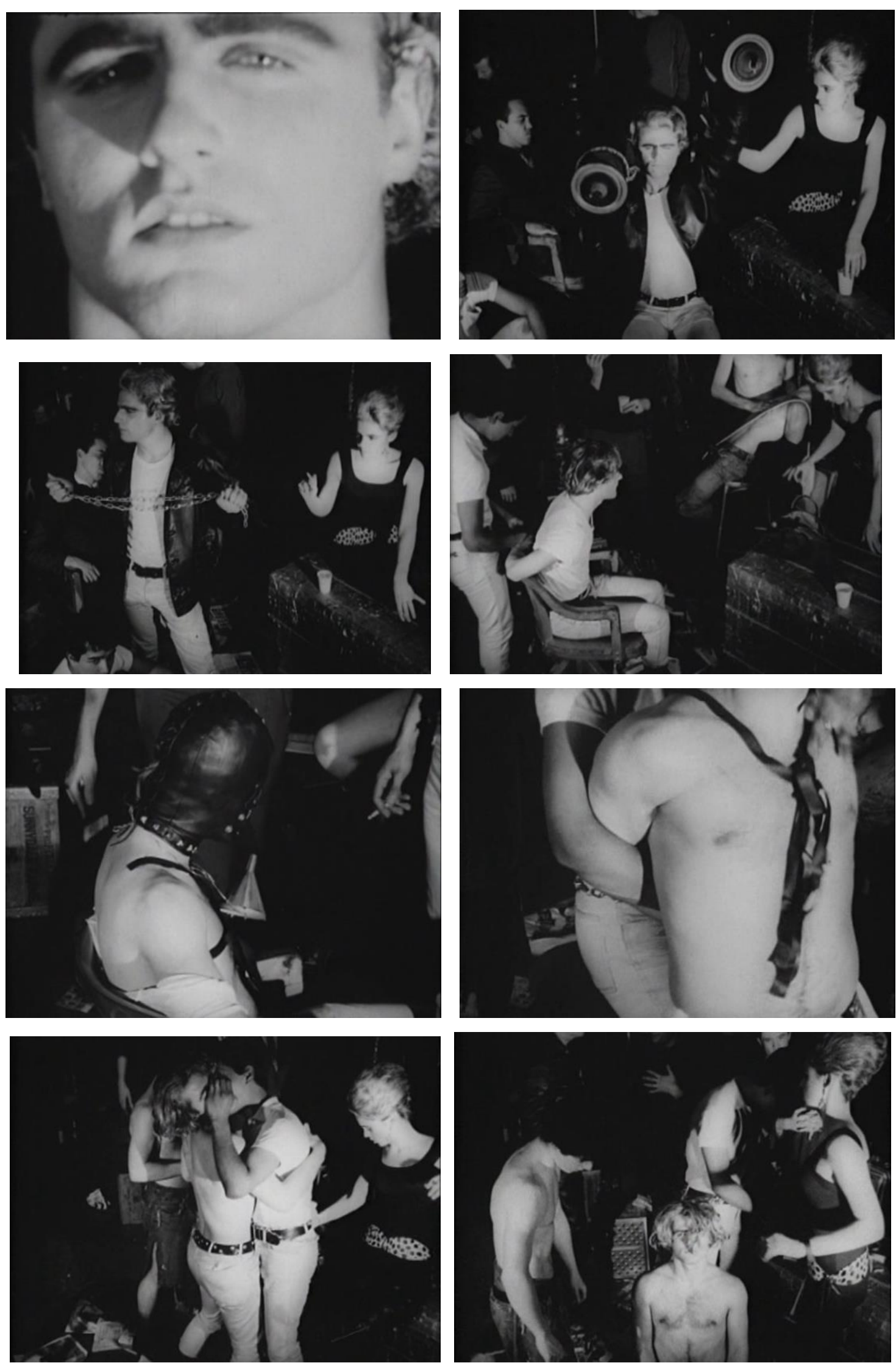

Vinyl (1965) 

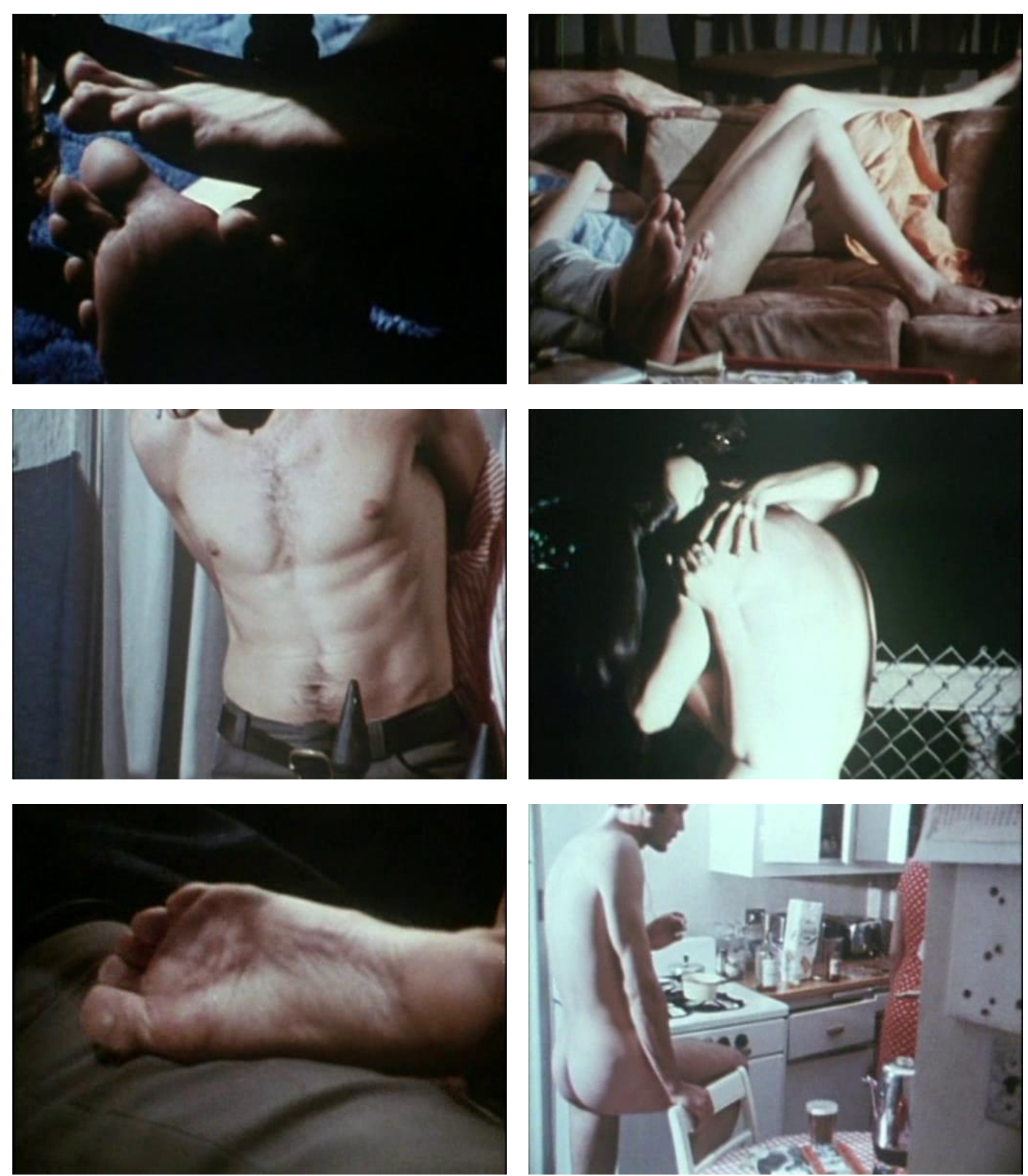

I, a Man (1967) 


\subsection{Pele e superfície}

No limite, todos os filmes de Warhol, ou quase, têm como objeto central a pele humana. Mesmo nos filmes em que não há nudez acentuada, a câmera invariavelmente se volta para partes descobertas: Eat é centrado na ginástica facial de Robert Indiana, o lento puxar e repuxar de uma pele que parece se tornar mais flácida com a projeção a 16 fotogramas por segundo. A complexa dinâmica performativa dos Screen Tests, que Callie Angell define como "experimentos psicodinâmicos" desveladores de personalidades (1994a, p. 2), nada mais são do que estiramentos corporais e faciais, um contínuo dobrar e desdobrar de poses, máscaras, expressões. Mais tarde, nos filmes sonoros, quando não pode mais controlar e circunscrever esses corpos retalhando-os e reduzindo-os a uma objetidade muda, Warhol passa simplesmente a ordenar que os atores fiquem nus: com a introdução do som, eles ficam mais livres, donos da palavra, "sendo eles mesmos", mas precisam estar nus para que a câmera continue observando o que sempre foi seu interesse primordial nessas figuras: sua pele.

Esse interesse pela pele apenas irá se confirmar nas polaroides que Warhol passa a tirar a partir dos anos 1970. As polaroides guardam uma grande semelhança com os filmes. Primeiro por constituírem um trabalho centrado em pessoas, fruto de um encontro direto entre artista e retratado. Segundo, por seu caráter amador: nessas fotos de celebridades, artistas e pessoas próximas de Warhol, a solenidade típica do retrato se dissolve nas qualidades materiais do meio. A descartabilidade da fotografia instantânea permite a Warhol bater diversas fotos da mesma pessoa, registrando poses mais espontâneas. Ao mesmo tempo, elas dispensam qualquer pretensão em captar uma interioridade dos retratados (o "eu interior" de que falava Cartier-Bresson), voltando-se para sua exterioridade. Numa câmera profissional, o foco e a distância focal atuam criando um espaço em profundidade que destaca a presença do retratado. A polaroide encurta esse espaço: tudo é posto sobre o mesmo plano, numa espacialidade chapada, selada pelo flash. Como nos filmes, o trabalho aqui tem um aspecto redutor: o evento estético fundamental reside no encontro da pele, sua superfície, com o flash da câmera e sua impressão direta sobre o papel fotográfico. Mesmo quando o retratado nos devolve um olhar profundo, a composição, a pose e a textura final chapada da foto deslocam a profundidade em potencial do retrato para um evento de superficie. Warhol frequentemente pedirá a seus modelos que fiquem parcialmente nus, e em diversos retratos femininos, como os de Jane Fonda, Liza Minelli [foto] e Bianca Jagger, o corpo 
foi maquiado antes para deixar a pele ainda mais branca, ressaltando-a ainda mais. No entanto, mesmo quando os retratados estão vestidos, é invariavelmente para sua pele que nosso olhar é conduzido, seja pela composição como um todo, seja por efeito do próprio flash, que ressalta as partes claras e cria ali o evento luminoso principal da foto.
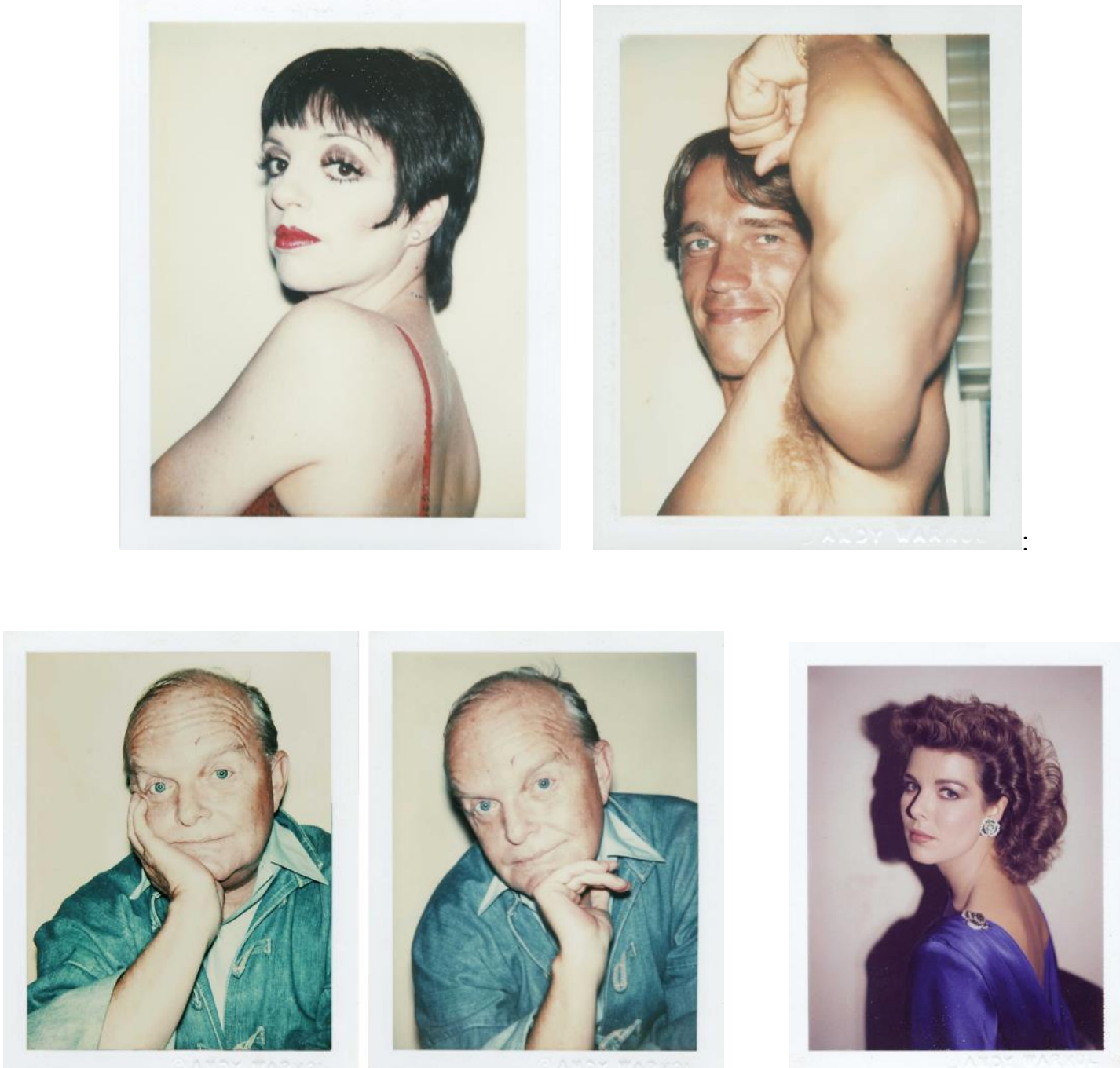

Polaroides: Liza Minnelli, Arnold Schwarzenegger, Truman Capote e Princesa Carolina de Mônaco

A máquina-Warhol atua esvaziando e reduzindo tudo à própria superfície, e, no caso das pessoas, esse processo tem como limite precisamente a redução do indivíduo à própria pele. A pele é a borda, o lugar onde o olhar maquínico da câmera e o corpo diante dela vêm finalmente se encontrar: é por meio dela que o corpo, reduzido à sua exterioridade, pode enfim ser transposto para a bidimensionalidade da imagem. Como nas polaroides, 
os filmes de Warhol frequentemente criam uma espacialidade chapada que ressalta o quão próxima a câmera está do corpo. O resultado dessa contiguidade, sobretudo nos primeiros filmes, é uma sobreposição e uma identificação entre a pele e a própria película em que o corpo se inscreve: a pele se mistura aos grãos, emerge como uma mancha precária em meio um preto profundo, sempre sob a ameaça de desaparecer novamente.

Deriva dessa fusão plena entre corpo filmado e suporte material a sensação extremamente táctil das imagens de Warhol. Assim, a pregnância corpórea geral dos filmes (dada pela disposição, pela nudez e pela preparação do corpo em geral) se completa com a inscrição deste corpo, de sua pele, sobre a película. O corpo se torna matéria luminosa. Mas essa luminosidade não é evanescente: a luz aqui é espessa devido ao alto contraste e ao aspecto bruto do $16 \mathrm{~mm}$. O halo é inscrito na matéria, ele carrega dentro de si o peso do grão da película. Nas intermináveis tomadas de Sleep, volta e meia confundimos os poros e o grão. A quietude do corpo faz com que eventualmente nosso olhar se volte para os ruídos da película subexposta. O materialismo warholiano impede que as imagens flutuem para além da contingência de sua fabricação. $O$ resultado não é exatamente abstrato, mas uma plena fusão entre o corpo dos modelos e o corpo da imagem.

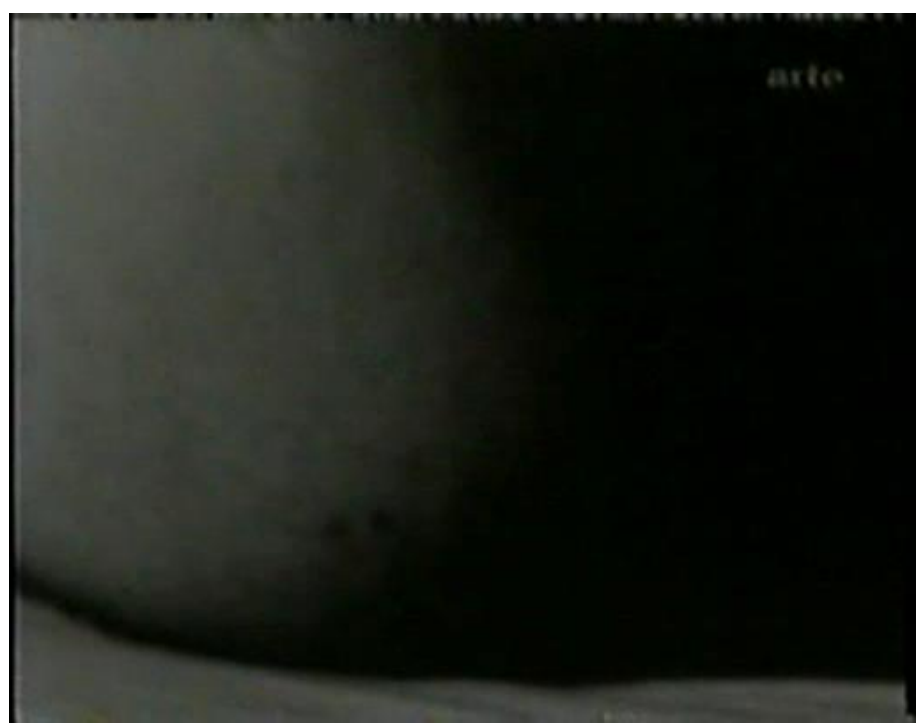

Sleep: o corpo do modelo se dissolve no corpo da imagem 
A pele é o lugar do desejo que move os filmes de Warhol: desejo de ver mais e mais, de desnudar os retratados. A pele é o que resta quando o corpo foi despojado de tudo o que há dentro, seu "eu profundo", e de tudo o que há fora, as roupas e adornos que codificam e dão personalidade a este "eu" numa visão exterior. O corpo-tornado-pele se transforma numa matéria indiferente, pronta a ser consumida pelo nosso desejo. A pele já é o pleno lugar da "dissolução do eu" que, na visão de alguns autores, caracteriza o ato sexual: o lugar onde o desejo se propaga para além de qualquer humanização. Nos filmes de Warhol, ele se realiza no encontro entre a câmera e os atores, cuja proximidade responde pelo olhar táctil dos filmes, sua operação de "braile mental".

\section{Sentido de superfície}

A superfície sempre foi o lugar por excelência do trabalho artístico de Warhol como um todo. "Vejo tudo dessa forma, a superfície das coisas, uma espécie de braile mental, apenas passo a mão sobre a superfície das coisas" (BERG, 1989, p. 54). Há muitas formas de se entender esse sentido de superfície na obra de Warhol. Em primeiro lugar, há a superfície do ícone: pois se a obra de Warhol pode operar uma aproximação entre arte e vida, trata-se de uma aproximação mediada pela superfície do design, da publicidade, da embalagem dos produtos. Em outras palavras, Warhol escolhe como motivos de suas telas produtos que já participam de uma economia das imagens. Há nele, portanto, um claro interesse pela "vida do ícone", uma imagem que é superfície porque afirma uma existência autônoma, destacada do objeto original. Um exemplo significativo são as diversas versões de suas One Dollar Bills: a nota de dinheiro como representação abstrata de valor, superfície alienada de seu próprio lastro. Ou as Marilyns, em que Warhol parte não da "pessoa" ou da "atriz", mas do fato imagético Marilyn, trabalhando a partir de um still pré-existente. A esse primeiro sentido de superfície, do ícone, é preciso acrescentar um outro, o sentido formal, que é dado pelo achatamento da espacialidade do quadro, a reiteração das marcas de impressão nas serigrafias, bem como pelo próprio estilo anônimo, que tenta eliminar qualquer traço de expressão de uma subjetividade (e portanto de profundidade metafísica). De muitas maneiras, portanto, a obra de Warhol como artista plástico se desenvolve sob uma "tirania da superfície".

No entanto, essa superficialidade em Warhol não se limita a uma práxis temáticoformal. Em termos mais amplos, trata-se de propor uma nova forma de se relacionar com a arte e as imagens. Afinal, se há um sentido de superfície em Warhol, ele parece ser 
muito diferente tanto do ideal de planaridade do expressionismo abstrato quanto daquele de um pintor como Jasper Johns, que faz a ligação entre os expressionistas e o pop. Vale aqui um brevíssimo retrospecto histórico. Quando Warhol começou a ambicionar ser artista, em meados dos anos 1950, o mundo da pintura norte-americana tinha como seus principais expoentes os expressionistas abstratos (Jackson Pollock, Willem de Kooning, Franz Kline) ao mesmo tempo em que via despontar alguns jovens artistas, como Johns e Robert Rauschenberg, ambos da geração de Warhol, que buscavam algo diverso e, em certa medida, respondiam ao expressionismo abstrato. ${ }^{9}$ Se para Pollock e outros a superfície era o lugar onde se imprimia o gesto pessoal, as emoções e, no limite, o próprio inconsciente do artista, para Johns, ao contrário, trata-se justamente de desmistificar o trabalho do pintor e negar toda metafísica. Sua pintura é anti-climática: ele emprega uma pincelada densa e profunda, ainda ligada um tipo de expressão modernista, aplicada a motivos banais (alvos, bandeiras, mapas). Só que, em sua "resposta" aos expressionistas, Johns ainda estava no mesmo campo deles. Deixando de lado a ironia contingencial dos motivos, suas telas podem ser facilmente vistas como uma afirmação da pintura pela pintura. ${ }^{10}$ Elas são tão "puras" quanto aquelas de Pollock ou as de um Rothko. Na realidade, são ainda mais "puras", já que nem o vínculo emocional do artista existe mais ali. Resta tão somente, literalmente, a "pintura", a tinta aplicada sobre a superfície da tela.

Warhol e os artistas pop, por sua vez, partem de um outro lugar. Embora venham na sequência do expressionismo abstrato e sejam contemporâneos a Johns, é muito difícil ver em suas obras uma resposta ou um diálogo efetivo com os expressionistas. ${ }^{11}$ Seu "sentido de superfície" é radicalmente, existencialmente, outro. Ele não se insere mais no telos modernista greenberguiano, segundo o qual a planaridade representava o ponto de chegada da pintura à sua essência. No pop, a superfície não traduz mais a essência da pintura, ela encarna a aparência das coisas. Há um corte aqui, e não à toa Greenberg, um dos grandes defensores do expressionismo abstrato, jamais conseguirá digerir o pop.

Para Frederic Jameson, a ideia de superfície de Warhol e do pop é já aquela do pós-modernismo. Essa superficialidade pós-moderna, na visão do autor, estaria intimamente ligada à ideia de simulacro. O simulacro é uma imagem que não tem mais a

\footnotetext{
${ }^{9}$ Entre as "respostas", há um trabalho de Rauschenberg intitulado Erased de Kooning Drawing, de 1953, literalmente "desenho de De Kooning apagado".

${ }^{10} \mathrm{O}$ laconismo dos trabalhos de Johns torna qualquer sentido de ironia neles algo muito distante, mas entre as anedotas conta-se que as latas de cerveja que figuram em sua Painted Bronze (1960) fazem referência a uma fala de "Willem de Kooning descrevendo a habilidade de seu agente, Leo Castelli, em vender virtualmente qualquer coisa, mesmo duas latas de cerveja" (FRANCIS, 2005, p. 64).

${ }^{11}$ Sobre essa dificuldade de ver uma resposta nas obras em si mesmas, ver Mesquita (2009), pp. 23-42.
} 
realidade como sua verdade última, mas que se reporta apenas a si mesma. Diríamos que ela é pura aparência. Apoiando-se no diagnóstico de fragmentação e do descentramento do sujeito contemporâneo, Jameson afirma que a experiência pós-moderna se aproxima àquela do esquizofrênico, para quem a cadeia de significantes do discurso é rompida, resultando num "amontoado de significantes distintos e não relacionados", incapazes de gerar um sentido global unificado (2007, p. 53). Essa disfunção linguística espelha, no âmbito psíquico, uma incapacidade de unificação temporal entre passado, presente e futuro (seja no campo do discurso, seja na vida). Resulta daí que a experiência do esquizofrênico seja marcada por um presente supremo, que "repentinamente invade o sujeito com uma vivacidade indescritível, uma materialidade da percepção verdadeiramente esmagadora" (ibid., p. 54). Essa ideia de um presente isolado, sem conexão com o mundo ou com o tempo, é o que marca a experiência das obras de arte pós-modernas para Jameson. E, nelas, o autor inclui Warhol e a arte pop. Analisando uma serigrafia tardia de Warhol, Diamond Dust Shoes (1980), Jameson se reporta ao conteúdo fetichista da obra e a sua apresentação à maneira de "uma coleção aleatória de objetos sem vida, pendurados na tela como se fossem nabos" (ibid., p. 35). Em seguida:

\begin{abstract}
Depois temos que acertar as contas com o papel da fotografia e do negativo fotográfico nesse tipo de arte contemporânea; e é exatamente isso que responde pelo aspecto de morte na imagem de Warhol, cuja elegância de um raio-X decorativo mortifica o olhar reificado do espectador de um modo tal que não parece ter nada a ver com a morte, ou com a obsessão ou ansiedade da morte no plano do conteúdo [...]. É como se a superfície externa colorida das coisas - aviltada e previamente contaminada por sua assimilação ao falso brilho das imagens da propaganda - fosse retirada para revelar o substrato mortal branco e preto do negativo fotográfico, que as subtende. Ainda que essa espécie de morte do mundo da aparência seja tematizada em alguns trabalhos de Warhol, mais notadamente nas séries de acidentes de trânsito ou de cadeiras elétricas, penso que não se trata de uma questão de conteúdo, mas de uma mutação mais fundamental, tanto no próprio mundo dos objetos - agora transformados em um conjunto de textos ou de simulacros - quanto na disposição do sujeito. (JAMESON, 2007, pp. 36-37)
\end{abstract}

A análise de Jameson nos parece bastante certeira. No entanto, ela tem uma carga negativa que gostaríamos de dispensar: pois o que talvez exaspere Jameson, esta revelação de um substrato de morte - que para o autor não é o tema da obra, e sim uma "mutação mais fundamental" de sua sensibilidade —, a nós parece justamente o que há de mais forte em Warhol. Em verdade, como distinguir o tema de uma obra (o fetiche por sapatos) de sua 
formalização (mortífera) uma vez que a forma é o próprio conteúdo? Como separar as coisas? É que Jameson está fazendo crítica cultural marxista: ele pensa a obra de Warhol como manifestação, subproduto ou resolução imaginária/simbólica de um campo cultural mais amplo, o pós-modernismo. $\mathrm{O}$ foco desta pesquisa, no entanto, é uma análise formal e autorista. Se para Jameson a análise formal da obra serve para revelar os sintomas culturais que a fundam, para nós, serve para revelar a sensibilidade do autor. No fundo, estamos fazendo o caminho inverso: Jameson vai do objeto ao contexto, nós vamos do objeto ao sujeito. E, no entanto, todos esses polos (objeto, sujeito, contexto) se comunicam, e é por isso que o texto de Jameson nos interessa, porque ele tenta dar conta dessa sensibilidade pós-moderna que, para ele, é o fundamento ontológico da obra de Warhol.

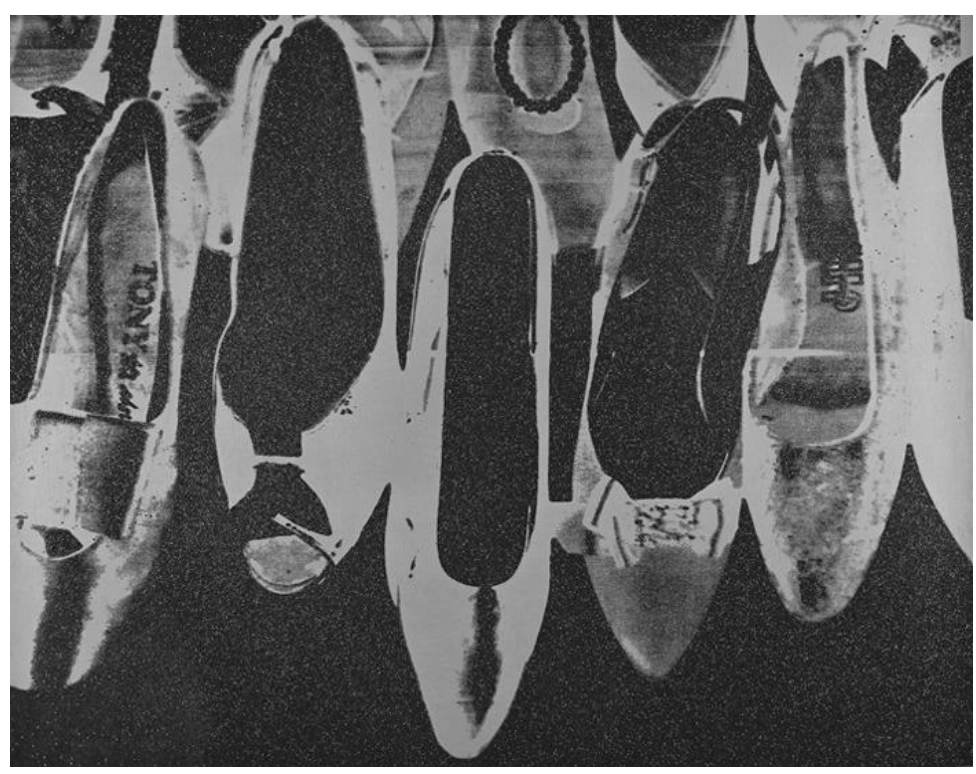

Diamond Dust Shoes (1980)

“A Pop Art pegou o interior e o pôs para fora, pegou o exterior e o pôs para dentro", dizia Warhol. ${ }^{12}$ A frase é deliciosamente ambígua. A princípio, em seu contexto, ela se refere à saída de cena do expressionismo abstrato para a "entrada" da pop. Mas ela também deixa sugerida a total inversão que o pop realiza: não mais expressar uma interioridade nas coisas, mas deixar as coisas (o Exterior) entrarem dentro de si e sentir através delas. Em outras palavras, não apenas sair da profundidade em direção à superfície, mas, uma

\footnotetext{
12 Tradução nossa. No original: "Pop Art took the inside and put it outside, took the outside and put it inside". A tradução brasileira é diferente e se centra no aspecto mais sugestivo e simbólico da frase: "A Pop Art pegou o Interior e virou para o Exterior, pegou o Exterior e virou para o interior". Na nossa, quisemos para ressaltar o aspecto dúbio da frase original de Warhol.
} 
vez na superfície, senti-la por inteiro, botar nela o coração, comprometer-se por inteiro com a aparência das coisas.

O melhor da arte pop, em nosso entender, são os trabalhos que conseguem propor uma relação existencial com a superfície e a aparência. Segundo Hal Foster (2005, p. 18), uma das diferenças da pop inglesa para a americana é que para os ingleses os ícones de consumo americanos eram "sedutores e exóticos", enquanto para os americanos "a paisagem de consumo havia se tornado quase uma segunda natureza" e os ícones eram tratados "desapaixonadamente" — a nostalgia e a desafecção estão entre as principais tonalidades no tratamento da arte pop de seus motivos. Se na obra dos britânicos Richard Hamilton e Eduardo Paolozzi era possível ainda visualizar um artista de fora que articulava conexões simbólicas entre as imagens, as obras de Warhol, Robert Indiana, Roy Lichtenstein e outros realizam uma sobreposição total entre a superfície da obra e o artista, que dá a impressão de ter sido absorvido, de se hipotecar ao ícone. ${ }^{13} \mathrm{~A}$ interioridade hipotecada à exterioridade. Resta daí os afetos que se cria a partir dessa superfície, dentro dela. Nos melhores casos, trazendo superfícies do mundo real, em partiular da sociedade de consumo, para o mundo da arte, e se entregando, obliterandose nessas superfícies completamente, os artistas pop conseguiam realizar um testemunho ambíguo dessa realidade. Via de regra, a superfície aparece isolada na obra e, nesse caráter não-relacional, ela apaga o artista: Warhol se apaga, Roy Richtenstein se apaga, o apagamento é um gesto comum na arte pop. Mas essa superfície testemunha algo. $\mathrm{O}$ melhor do pop talvez não seja nem excitante, nem irônico, nem glamoroso, mas dúbio. Pensemos no aspecto plástico e barato de algumas Still Lifes de Tom Wesselman e na artificialidade grotesca e repulsiva das comidas de Claes Oldenburg: o gesto está oculto, apagado sob a superfície, mas essas obras irradiam pelos seus próprios materiais um brilho artificial que já traz, em si, um gosto mortífero. Essas obras são sem dúvida alguma "pura superfície", no sentido mais literal, mas ainda assim elas irradiam um circuito de sensações. Em Warhol, a fantasmagoria, a náusea e a meditação sobre a morte — tema que se completa com o aspecto mortífero do fotográfico evocado por Jameson — são algumas das sensações mobilizadas pelas das obras, para além das questões conceituais que elas criaram (e criam até hoje) para a história da arte.

\footnotetext{
${ }^{13}$ Uma exceção a essa tendência é sem dúvida James Rosenquist, cujo estilo alucinadamente associativo se aproxima mais dos ingleses.
} 


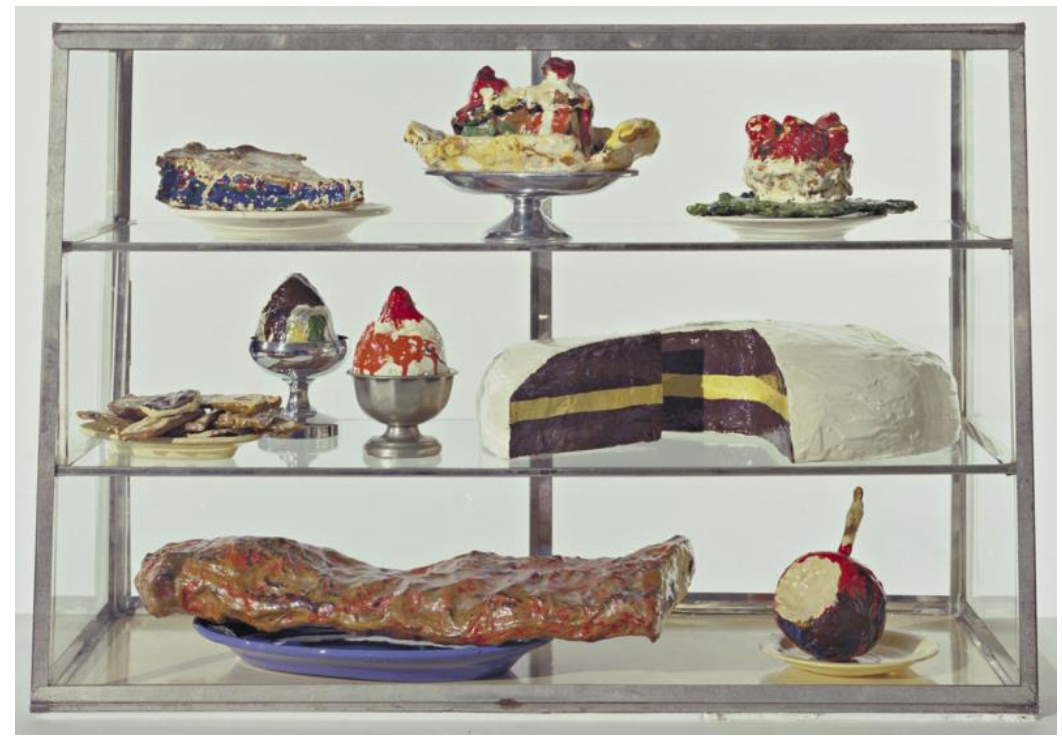

Claes Oldenburg, Pastry Case, I (1961-62)

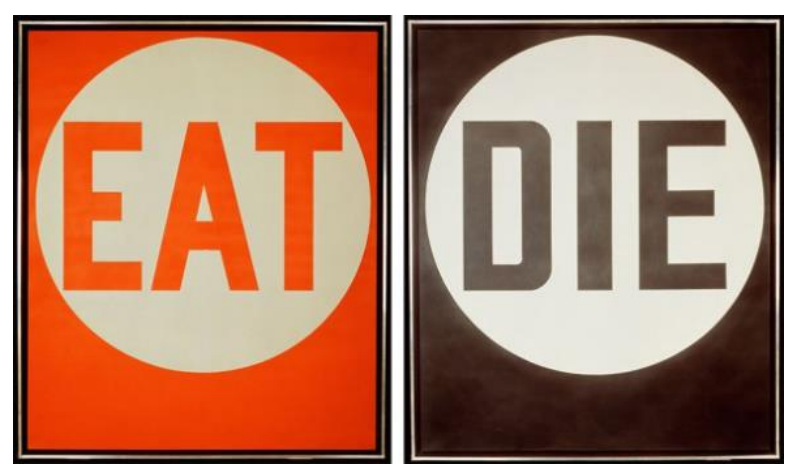

Robert Indiana, Eat / Die (1962)

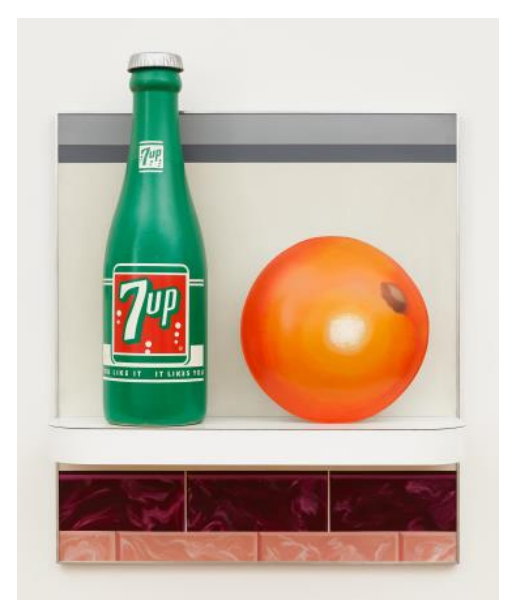

Tom Wesselman, Still Life \#49 (1964)

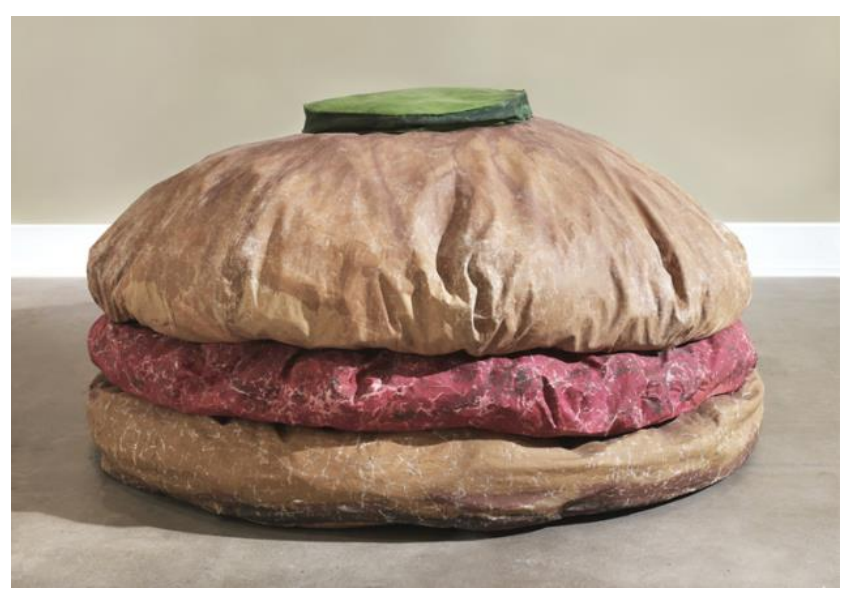

Claes Oldenburg, Floor Burger (1962) 
Dito de outra forma, há um vazio no coração das latas de sopa Campbell enfileiradas, mas para Warhol se trata justamente de repensar esse vazio como experiência. Sua Filosofia será justamente a formalização conceitual deste projeto existencial: "O melhor clima em que consigo pensar é o do cinema, porque é tridimensional fisicamente e bidimensional emocionalmente"; "prefiro observar alguém comprando cuecas a ler um livro que essa pessoa escreveu"; "o negócio é pensar em nada [...] nada é excitante, nada é sexy”; "sexo é muito mais excitante na tela e entre as páginas do que entre os lençóis"; etc. ${ }^{14}$

Para Jameson, Warhol e as obras pós-modernas em geral encarnam um esmaecimento do afeto, em que a "estética da expressão" tipicamente modernista daria lugar a um mero circuito de "intensidades" (2007, p. 38). Essa leucemia afetiva também é diagnosticada por Steven Shaviro (2004), num texto que também procura ler a obra de Warhol à luz do pós-modernismo e do simulacro. Mas para Shaviro há uma fraca luz no fim do túnel: ele afirma que as obras de Warhol encenam uma "morte e ressurreição" das emoções. Shaviro associa a ideia baudriallardiana do simulacro à "aura", entendida como a imagem que se interpõe entre o consumidor e os objetos, distanciando ambos, e por meio da qual o conhecido processo de fetichização da mercadoria opera. Atendo-se à aura dos objetos, Warhol os mata, uma vez que a aura, como o simulacro, prescinde do objeto propriamente dito. Mas essa morte não é definitiva: pois uma "emoção zumbi" "retorna da cripta", mediada pelo artifício da publicidade e da cultura midiática em geral (p. 139). Uma emoção "impessoal e anônima”, de segunda mão, mas que é aquela possível nos nossos tempos de cinismo, ironia e cansaço - uma emoção, afirma Shaviro, "debochada, perversa, caprichosa, esbanjadora, fútil, disfuncional, extravagante e ridícula” (p. 140).

E o que resta das emoções e dos afetos quando o que se tem diante de si não são mercadorias ou anúncios publicitários, mas pessoas? Como essa emoção reificada, esmaecida, “zumbi”, se manifesta nos filmes? "Depois dos anos 1960 nunca mais pensei em termos de 'amor'. Porém fiquei o que se pode chamar de fascinado por algumas pessoas", afirma Warhol (2008, p. 42). Essa fascinação pelas pessoas é em boa parte o elemento fundador do cinema de Warhol, em seu impulso retratístico de fazer dos filmes veículos para as superstars. Mas fascinação, escreve Shaviro, "é o fantasma do amor. [...]. É o amor estetizado. Um amor 'indiferente à existência do objeto', ainda que tirando prazer das qualidades e formas abstraídas do objeto" (2004, p. 139).

\footnotetext{
${ }^{14}$ Warhol (2008) respectivamente: pp. 182, 22, 255, 58.
} 
Há então algo de ambíguo na fascinação. Ela é um magnetismo que nos captura profundamente, mas que ao mesmo tempo escraviza e reifica aqueles que são alvo de nosso olhar (e desejo). Tirar "prazer das qualidades e formas abstraídas" de alguém nada mais é do que a pura e simples definição de objetificar. Nos filmes de Warhol, esse processo de objetificação ganhará contornos fortemente sexuais, constituindo um tipo de erotismo muito particular. Um erotismo que se funda no "corpo puro", o corpo tornado objeto, o corpo reduzido à própria pele. Veremos agora alguns contornos dessa fascinação erótica nos filmes de Warhol.

\title{
2.3. Erotismo
}

\begin{abstract}
Pessoalmente, eu adorava pornô e comprava uma porção de revistas o tempo todo - as bem sacanas e excitantes. Tudo o que se precisava fazer era descobrir o que excitava você e simplesmente comprar as revistas e filmes de sacanagem certos, do mesmo jeito que se compra comprimidos certos e latas de comida certas. (Eu era tão ávido por pornografia que na minha primeira saída depois dos tiros fui diretamente para a rua 42 e conferi todos os peep shows com Vera Cruise e renovei minhas revistas de sacanagem). ${ }^{15}$
\end{abstract}

Andy Warhol

Um olhar mais apressado sobre a trajetória de Warhol pelo cinema pode sugerir o caminho entre uma aproximação vanguardista inicial e uma posterior concessão ao cinema comercial com realização dos chamados filmes de sexplotation. Em outras palavras, a passagem do artista que realizava filmes movido apenas por sua própria vontade para um produtor que entrevê um nicho de mercado - um business artist, para usar as palavras do próprio Warhol. De um ponto de vista exterior, essa "evolução" da carreira de Warhol é inegável. Mas há algo que se coloca entre os dois polos, ligando-os: o sexo. O sexo sempre foi uma das obsessões de Warhol, e entre suas diversas práticas artísticas talvez tenha sido justamente através do cinema que ele melhor conseguiu dar vazão a esse impulso. ${ }^{16}$ Já entre os filmes silenciosos da primeira "fase", rodados com

\footnotetext{
${ }^{15}$ WARHOL, 2013, p. 350.

${ }^{16}$ Nesse rol há igualmente diversos desenhos de pênis que Warhol fez ao longo da carreira, e quando passou a usar a câmera polaroide ele relata que fez "milhares de polaroides de genitais. Sempre que
} 
pequenos rolos de 3-4 minutos, o sexo como "tema" aparece explicitamente em filmes como Blow Job e Couch - Couch possui até mesmo cenas de sexo explícito, algo que só se repetiria em Blue Movie.

No entanto, a obsessão de Warhol pelo corpo e pela pele denota um impulso sexual latente que contamina o olhar dos filmes como um todo. A ideia de "latência" aqui é importante. Pois mesmo quando a motivação sexual se torna explícita nos filmes da fase sexplotation, o sexo ainda assim permanece numa forma latente. A latência não se consuma. Filmes como I, a Man e Bike Boy se estruturam em conversas que precedem ou sucedem o ato sexual propriamente dito. São preparações para um ato em vias de ocorrer, ou descompressões de um ato sexual já passado. Há uma energia sexual que percorre as tagarelações, os corpos nus, as poses, mas que permanece presa, sem se liberar. Não porque ela não pode se resolver: ainda que o sexo explícito fosse proibido no cinema americano nos anos 1960, Warhol poderia encontrar outras formas de canalizar essa energia, distribuindo-a, sublimando-a. Mas ele parece simplesmente não querer isso: ele quer que seus personagens permaneçam ali, parados, sentados, falando sem parar sobre sexo, numa libidinagem repetitiva, anestesiada, que com o tempo se torna apática e modorrenta.

O erotismo de Warhol é um erotismo flácido. A câmera passeia, erra sobre a pele dos personagens: mulheres, homens, jovens esculpidos, tecidos flácidos. Tudo interessa igualmente à câmera de Warhol, tudo fascina. Seu erotismo não se codifica em situações "prontas". Georges Bataille dizia que "o erotismo é um dos aspectos da vida interior do homem" (2013, p. 53). O erotismo implicaria, assim, necessariamente na existência de uma consciência engendrando relações sobre a realidade. Como falar de uma consciência em Warhol? Sua câmera estaria mais para um olho descerebrado que passeia pelas superfícies, apegando-se à exterioridade das coisas.

Os corpos em Warhol são corpos sem mistério. Eles não escondem nada, portanto são incapazes de uma potência revelatória: sua potência é quando muito fascinatória. A visibilidade pura e total que Warhol impõe a eles, recusando a montagem e obrigando-os a permanecer diante da câmera, constitui uma relação que, a despeito da ausência de sexo explícito, poderia ser caracterizada como pornográfica, na medida em que não preserva nenhum espaço para o imaginário. Falamos pornográfico sem qualquer conotação negativa, num sentido próximo do que Susan Sontag chama de “imaginação 
pornográfica", isto é, a pornografia como uma forma possível de arte. ${ }^{17}$ No entanto, na prática, há um abismo entre os filmes de Warhol e a pornografia comercial mais conhecida. A pornografia tem códigos: ela está o tempo todo criando relações simbólicas, a cada mudança de posição, a cada expressão. Os filmes de Warhol operam de uma forma diferente. Eles não se dão ao trabalho de articular um código. Eles apenas mostram. Mas nesse mostrar eles aprisionam com o olhar. Assim, mesmo "descodificados", os corpos não são livres: pois eles são o tempo todo olhados, vigiados pela câmera.

A sexualidade em Warhol passa, portanto, pela câmera. O dispositivo warholiano estabelece uma área de circulação de uma pulsão: uma pulsão escópica, o prazer de olhar. É a presença dessa pulsão que responde pela latência sexual dos filmes. Essa pulsão é constante, atravessa os filmes de ponta a ponta, sem sofrer modulações. Trata-se de um erotismo anticlimático, sem qualquer pretensão catártica ou vitalista. As cenas são circulares, não evoluem, não progridem: mesmo Blow Job parece não acabar nunca (falaremos dele a seguir). Pois o erotismo de Warhol é fixado numa relação perversa com os corpos. Dizemos perverso não apenas no sentido comum do termo, embora os filmes de Warhol sempre mobilizem uma maldade de fundo, mas também no sentido freudiano, se por perversão entendemos os desvios de uma pulsão que termina por nunca chegar ao seu "alvo" principal, o orgasmo ou o coito. Essa pulsão desviante se fixa em etapas “provisórias" (ver, tocar), "transgressões anatômicas", fetiches (a pele). ${ }^{18}$ Dessa atividade pulsional viciada, presa numa fetichização frívola do corpo, resulta um erotismo frio e desafetado.

Mas ater-se ao modelo freudiano, com suas limitações, talvez seja perder de vista o que esses filmes têm de potência positiva. Mario Perniola (2005) tem uma proposta interessante: uma "sexualidade neutra", centrada no sex-appeal do inorgânico. Uma experiência "descentrada, livre da intenção de atingir um objetivo", uma sexualidade "emancipada de uma concepção instrumental da excitação sexual que a considera naturalmente direcionada para a obtenção do orgasmo" (p. 22). Algo bastante próximo, portanto, da excitação anticlimática proposta pelos filmes de Warhol. Perniola baseia sua sexualidade neutra na possibilidade de um sentir como coisa, um "impulso para o artificial” (p. 47), para o inorgânico, que, no limite, estaria além do próprio sensualismo

\footnotetext{
${ }^{17}$ O ensaio de Sontag (1987a) discute a possibilidade da pornografia como categoria literária e analisa algumas obras que se enquadrariam nesse gênero, como A história do olho, de Bataille, e Historia de $O$, de Pauline Réage.

${ }^{18}$ Cf. Freud, "Três ensaios sobre a teoria da sexualidade".
} 
perceptivo. ${ }^{19}$ Ora, a relação vampiresca que a câmera de Warhol estabelece com seus retratados não constituiria um paradigma de sexualidade inorgânica? O objetivo de Warhol no fundo não sempre foi nos fazer sentir o mundo através da máquina, sentir como ela? Daí o caráter anestesiado de suas imagens (anestesiado pela prótese da máquina): elas não nos mostram a realidade transparente como a pornografia, mas nos oferecem um corpo metalizado, luminoso, inorgânico, que se confunde com o corpo da imagem. "Sexo é mais excitante na tela e entre as páginas do que entre lençóis" (WARHOL, 2008, p. 58): entregar-se aos filmes de Warhol, à experiência altamente sexualizada que eles propõem (como, aliás, as polaroides e diversos outros trabalhos seus) é precisamente se entregar a esse sex-appeal do inorgânico, à excitação pelo artificial.

Não há filme que dê conta melhor desse erotismo anticlimático, não catártico, do cinema de Warhol do que Blow Job. A maior parte das análises tende a ver o filme como uma provocação ou pegadinha: fala-se em geral da frustração provocada no espectador por aquilo que o filme não mostra, a expectativa não cumprida. No entanto, fala-se pouco daquilo que ele efetivamente mostra: um rosto. A plenitude de um rosto. É evidente que a imaginação do ato sexual fora-de-campo é prazerosa. Mas esse ato está impresso no rosto. E o rosto não apenas manifesta o prazer relativo a uma ausência. Ele tem um prazer em si mesmo. Do ponto de vista da sexualidade fetichista e desafetada de Warhol, o filme é absolutamente explícito. Não é uma questão de puritanismo: o prazer que o filme quer nos transmitir é o prazer de olhar um rosto. Basta olhar os filmes de Warhol como um todo para ver como Blow Job ocupa um lugar absolutamente orgânico em sua obra: o prazer de olhar o outro, o rosto do outro, é idêntico ao das dezenas de Screen Tests. A encenação em Warhol, dizíamos lá atrás, é centrípeta. Seja em Blow Job, seja em outros filmes em que expressões dos atores são induzidas por vozes em off (Beauty \#2, Screen Test \#1). Simplesmente não há espaço para a imaginação na encenação "pornográfica" de Warhol: depois de alguns minutos, nos contentamos em apenas apreciar aquele rosto, e tirar prazer diretamente dele. E nessa plenitude Blow Job não deve ser entendido como um longo caminho postergando o gozo final. O gozo é pro forma, ele é um anticlímax. É

\footnotetext{
${ }^{19}$ Assim, no limite o sex-appeal do inorgânico se equipararia à filosofia, ao ato (não sensível) de pensar. Perniola: "Até que ponto a experiência da coisa é estranha ao sensualismo perceptivo ninguém mostra melhor que Hegel, para quem a certeza sensível é o que existe de mais abstrato e universal. Erroneamente se acredita que os sentidos nos garantam uma experiência concreta e determinada: na realidade, no aqui e agora do sentir imediato, o dado apenas se dissipa continuamente e é substituído sem cessar por um outro dado. O corpo que mantenho apertado entre meus braços, a partir do momento em que se entrega a mim como coisa, deixa de ser um objeto particular e se torna um 'não isso', subtrai-se de todas as determinações específicas" (2005, p. 64). No fundo, o texto de Perniola parece ter como horizonte a ideia, razoavelmente conhecida, da sexualidade como dissolução do eu.
} 
o caminho em si mesmo, este "olhar um rosto por meia-hora", que é o "fim". Como se precisasse deixar isso mais claro, Warhol ainda alonga os rolos do filme ao projetá-los a 16 fotogramas por segundo. Não é possível falar em clímax final uma vez que não existem modulações. Evidentemente, os que não percebem que o filme é sobre "o prazer de olhar um rosto" só podem detestá-lo. Ou lê-lo como peça conceitual, mas por que uma peça conceitual precisaria durar 34 minutos? Trinta e quatro minutos não é nem o tempo de uma masturbação (do espectador), nem de uma felação (do modelo), é apenas o tempo necessário para aprendermos a ver com Warhol, para olharmos como ele.

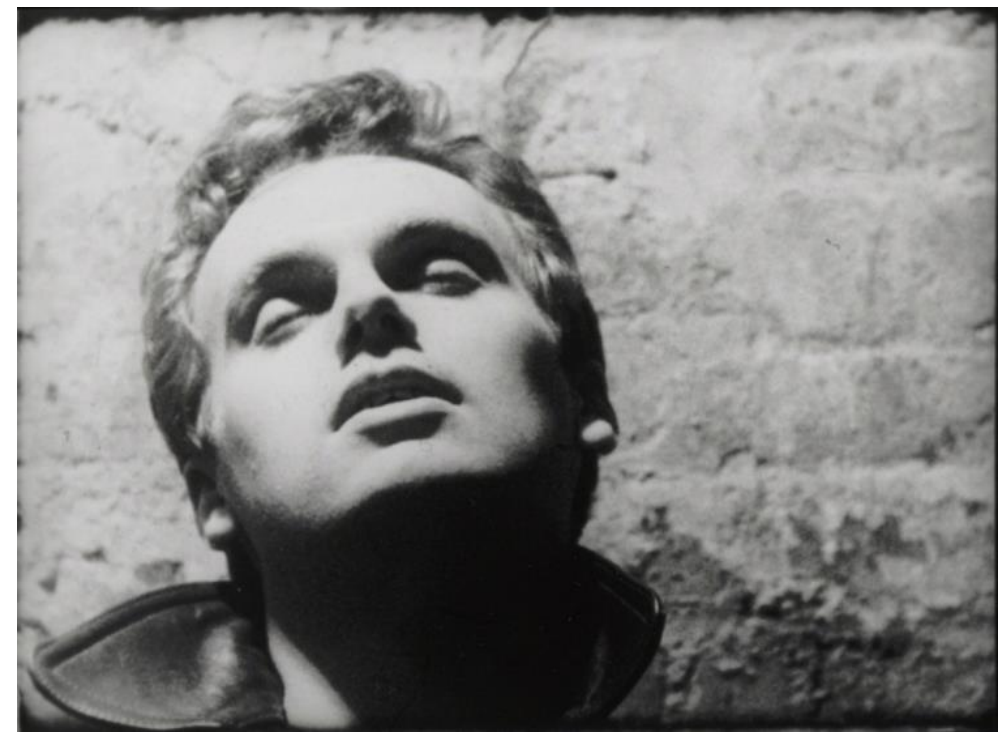

Blow Job (1964)

\section{Objetificação e voyeurismo}

Tudo isso nos leva à questão do voyeurismo dos filmes de Warhol. Foi Stephen Koch o primeiro a notá-lo: "o voyeurismo domina todos os primeiros filmes de Warhol e define sua estética" (2002, p. 42). Num dos muitos trechos inspirados de seu livro Stargazer, originalmente publicado em 1973, ele escreve sobre Blow Job:

Blow Job é uma espécie de filme-retrato - o retrato de uma anonimidade. $\mathrm{O}$ receptor se assemelha a um escoteiro de rosto outrora fresco, firme, um veterano em incontáveis competições de arco-eflecha e banquetes ao ar livre que descobre, em meio ao processo de se 
tornar o menino-americano-perfeito, alguns frágeis nervos psíquicos que terminam por enviá-lo impotentemente a escorregar em atividades para as quais nenhuma insígnia é concedida, nas quais ele percebe o corpo que adquiriu em todas essas reuniões e caminhadas na floresta tornando-se oco nos olhos, entrando levemente em decomposição [faisandé]. Então ele leva esse corpo para Nova York, e se dá conta de que é uma mercadoria muito vendável. Um grande número das vedetes de Warhol começou a carreira como garotos de programa homossexuais. Parece uma aposta bastante segura dizer que a estrela de Blow Job faz parte dessa categoria. (KOCH, 2002, p. 48) ${ }^{20}$

Douglas Crimp, um dos autores que recentemente tenta reler a obra de Warhol pelo viés dos estudos queer, se levantará diretamente contra esse trecho de Koch. Ele ataca o tom "malicioso, sabe-tudo, condescendente" da escolha de palavras de Koch. Mais do que isso, ele vê na alusão de Koch a uma "fragilidade" e "impotência" em resistir a impulsos homossexuais uma narrativa de degradação de cunho estritamente moralista e homofóbico (2012, p. 2).

Que o texto de Koch constrói uma "narrativa de degradação", isso não há dúvidas. No entanto, diferentemente do que pensa Crimp, ela não nos parece condenatória ou moralista. Koch está realizando um procedimento ensaístico: ele cria uma narrativa imaginária para aquele rosto a fim de dar conta das sensações provocadas pelo filme. Sem dúvida, ele está objetificando o personagem do filme ao projetar sobre aquele rosto anônimo uma narrativa criada em sua própria cabeça, que diz respeito unicamente a ele. ${ }^{21}$ Mas essa objetificação revela, em seu fundo, não desprezo ou reprovação, mas precisamente fascínio. Koch parece fascinado pela narrativa que descreve. ${ }^{22}$ De forma que, se há um moralismo aqui, é aquele de Crimp em relação à objetificação de Koch.

O trecho de Koch interessa porque deixa entrever no centro da própria narrativa criada a ambiguidade e a dialética fundamentais da obra de Warhol como um todo: aquela

\footnotetext{
${ }^{20}$ Tradução nossa. Como a prosa de Koch é sinuosa, deixo aqui o trecho original: "Blow Job is something of a portrait film - the portrait of an anonymity. The recipient looks like a once fresh-faced, foursquare Eagle Scout, a veteran of countless archery contests and cookouts, who discovers in the process of becoming the all-American boy some weak psychic nerves that send him helplessly gliding to activities for which no merit badges are awarded, in which he discovers the body he acquired on all those jamborees and tramps in the woods is becoming a bit hollow-eyed, just a touch faisandé. Whereupon he takes that body to the Big Apple, where he finds it to be a very sellable commodity. Large numbers of Warhol leads began their careers as homosexual hustlers. It seems a pretty safe bet that the star of Blow Job belongs in their company".

${ }^{21}$ Sobre projeção como objetificação, ver Rae Langton, "Projection and Objectification", in Sexual Solipsism. Oxford: Oxford University Press, 2009, pp. 285-303.

${ }^{22}$ É verdade que ao longo de seu livro Koch demonstra desprezo pelos filmes tardios de Warhol, referindose a eles como uma "degradação". Mas, concorde-se ou não, ele tem argumentos para uma discussão no campo da arte. Aqui estamos nos referindo ao procedimento ensaístico, à escolha de palavras deste trecho especificamente, sobre um filme (Blow Job) que Koch, aliás, tem em alta estima.
} 
entre a faceta ideal da América e tudo o que se encontra em seu verso, obliterado por ela - a morte, o consumo e, no caso dos filmes, o inventário de uma sexualidade reprimida, notadamente a homossexualidade, o travestismo e o sadomasoquismo. Todo o melhor da obra warholiana é fundado numa dialética ambígua entre o desejo e a repulsa, o prazer e a náusea, a plenitude e o vazio em seu interior. Todas essas são faces de uma mesma moeda impressas sobre um rosto, como nas telas das Marilyns, das Jackies, entre outras. Os filmes de Warhol se propõem, em sua forma, como veículos para suas superstars: eles miram uma espécie de glamour intrínseco ao cinema, mas o que fazem emergir em sua superfície, ao fim e ao cabo desse processo, é uma projeção de estrelas degradadas (Edie Sedgwick, Viva, Mario Montez e todo o resto da fauna de metanfetaminados da Factory), impregnadas por uma sexualidade latente que está na origem do olhar de Warhol sobre as próprias coisas.

Voltando agora à questão do voyeurismo especificamente. Crimp argumenta que Blow Job fornece uma "ética do antivoyeurismo", pois, uma vez que os olhos do personagem estão cobertos por sombras, não conseguimos "fazer contato visual [...] e detectar a vulnerabilidade que essa submissão ao prazer implica. Não conseguimos possuí-lo sexualmente" (2002, p. 7). O argumento da vulnerabilidade é interessante, mas ele não implica exatamente que o filme não seja voyeurista (e de todo modo conseguimos ver os olhos do personagem sempre que ele olha para cima). Não ajuda também que Crimp tente vender o filme como "uma lição sobre como produzir um lindo retrato melhor do que dizendo "xis"” (p. 9), ou seja, como um esteticismo inócuo. Se o voyeurismo em Warhol pode ser relativizado, é por outra razão: pelo fato de que a presença da câmera via de regra afeta as performances dos atores — ainda que isso não pareça ocorrer especificamente em Blow Job. Por definição, o voyeurismo implica que aquele que é visto não saiba que está sendo olhado. Ele implica na ausência aparente do voyeur. Esse "problema” leva David James (1989) a pensar os filmes de Warhol nos termos do exibicionismo de seus intérpretes. Só que os intérpretes de Warhol estão longe de demonstrar prazer ao performar: ao contrário, os filmes frequentemente possuem um ar de tortura, de uma câmera que se apodera dos corpo e o força a permanecer ali, realizando certos gestos.

A questão é que boa parte dos filmes de Warhol, como vimos no primeiro capítulo (“1.4. Dispositivo e prazer de olhar”), opera por meio de um dispositivo. Isso vale sobretudo para os filmes em que a câmera é fixa. O dispositivo realiza uma dupla operação: ele estabelece uma situação interna ao mesmo tempo em que distancia o diretor 
dessa situação. Ele consiste em estabelecer uma arena, uma área com uma setagem, produzindo uma situação cujas consequências estão fora do alcance do diretor. Diferentemente da mise-en-scène, em que a câmera é uma instância ativa que expressa o olhar do diretor, no dispositivo não há necessariamente essa identificação. A câmera é um instrumento de um sistema mais amplo. O diretor pode armar a situação e "se retirar" — mesmo que seja para estar ao lado. É o que acontece em Warhol. A câmera é um "olho de vidro", um espelho cego para o qual os atores performam. E Warhol assiste a eles performarem para a câmera. Não importa que eles estejam autoconscientes, pois o voyeurismo se faz neste campo cego entre um ator que performa-para-a-câmera e um espectador (Warhol, ou nós) ausente, distanciado pelo dispositivo, um espectador que não se identifica à câmera.

Dito de outra forma, o dispositivo cria uma assimetria na relação ator-câmeradiretor: é nessa assimetria que o voyeurismo se faz. Essa relação assimétrica se repete se pensarmos na situação do espectador diante do filme. Pois Warhol, como vimos no primeiro capítulo, coloca o dispositivo em cena. O dispositivo em cena, como havíamos dito, cria uma situação de espectatorialidade duplicada: ele nos mostra que está mostrando. Assim, há uma situação interna (o ator que performa-para-a-câmera) da qual somos distanciados pelo dispositivo em cena. E o voyeurismo se faz novamente nesse distanciamento, nesse campo cego que ocupamos fora da relação direta, de espelho, entre câmera e ator.

A coisa muda quando Warhol passa a usar zooms (Chelsea Girls, My Hustler) e depois cortes (I, a Man). Nesses filmes, o olhar se liberta: a câmera revela uma intenção. A dinâmica aqui é mais próxima daquela da mise-en-scène. O voyeurismo se expressa diretamente pelo olhar da câmera. Em Chelsea Girls, a câmera passeia pelos corpos e rostos dos atores, frequentemente em desencontro com o que está sendo dito. Assim, não importa que os atores tenham consciência de estarem sendo filmados, pois eles não conduzem o olhar da câmera (Douglas Crimp nota que essa condução pelo ator acontece apenas em um filme de Warhol, Mario Banana, com Mario Montez, mas trata-se de uma clara exceção). A câmera, via de regra, é insubordinada, ela olha o que quer da cena que os atores percebam. Não há uma relação de solidariedade entre ela e a performance, mas antes uma relação de perversidade. Aqui, novamente, o voyeurismo se faz nesta fissura, nesse campo cego entre um ator que performa-para-a-câmera e uma câmera que olha aquilo que lhe interessa dentro dessa performance. 


\section{Universo queer}

Dissemos que quando Warhol passa a usar zooms e cortes seu "olhar" se libera. A câmera vai diretamente ao que interessa. Ela explora a geografia do corpo, dando continuidade a um processo iniciado lá atrás, em Sleep. Rostos, peitoral, costas, pé, bunda. Mais do que isso, a câmera de Warhol revela uma predileção: o corpo masculino é significativamente mais explorado do que o feminino. Às mulheres são reservados belos e fascinados close ups. No entanto, quando o nu feminino aparece, é via de regra para interagir com o masculino. Já o corpo masculino, sobretudo o do hustler, é alvo de muito mais escrutínio. Apesar de despir homens e mulheres igualmente, fascinar-se por ambos, à medida que a obra de Warhol evolui não resta dúvidas de que o olhar do artista tem um fundo essencialmente homoerótico. E que se trata de um olhar espontâneo, não de uma “concessão" a um nicho de mercado.

Isso nos leva à relação dos filmes de Warhol com o mundo do cinema gay propriamente dito. Essa relação costuma ser feita através da sensibilidade camp de Warhol. O camp era certamente um dos elos mais fortes de articulação identitária no mundo gay nos anos 1950 e 60 nos Estados Unidos, por meio de uma afinidade de gostos. Como esclarece Susan Sontag em seu clássico ensaio, o camp não é um movimento nem mesmo uma "ideia", mas uma sensibilidade, um gosto que se define, entre outras coisas, por uma predileção "pelo artifício e pelo exagero" (1987b, p. 318). Por isso mesmo, o camp possui uma íntima relação com o drag, o travestismo, que dentro do cinema underground americano ganhará corpo sobretudo nos filmes de Jack Smith reaparecendo também em alguns filmes do próprio Warhol, que nunca escondeu sua influência de Smith. As abordagens das relações entre o camp e o cinema underground - e aqui se inclui, além de Warhol e Smith, também alguns filmes de Kenneth Anger, Ron Rice e Barbara Rubin — tendem a se focar na apresentação, por esses filmes, de uma sexualidade "não normativa" e na irreverência paródica do camp enquanto formas de transgressão frente a uma cultura puritana e heteronormativa. Essa cultura ainda era marcada naquela época pelas "leis de obscenidade" da suprema corte americana, que invariavelmente se voltavam com mais rigor contra o comportamento homossexual. Janet Staiger (2000) mostra como o cinema underground americano, em sua apresentação de comportamentos e sexualidades "desviantes" e em seu constante embate com a censura, ${ }^{23}$

\footnotetext{
${ }^{23}$ Entre os episódios mais conhecidos de censura encontram-se a de Flaming Creatures, de Smith, e a de Un Chant d'amour (1950), de Jean Genet, quando de sua exibição na Film-Makers' Coop por Jonas Mekas.
} 
constituiu uma arena importante de abertura e diálogo para os movimentos civis dos anos 1960, sobretudo o da liberação gay, que culminaria na rebelião de Stonewall, marco na luta pelos direitos civis homossexuais, em 1969. Nessa "abertura" do underground, afirma ainda Staiger, Warhol teve papel particularmente importante com o sucesso de Chelsea Girls, cuja projeção alcançada na mídia mainstream se deveu em grande parte à fama já estabelecida de Warhol como artista pop. ${ }^{24}$

Aqui, no entanto, gostaríamos de nos focar na face interna da transgressão e do exibicionismo camp, um terreno menos social e mais subterrâneo: aquele do desejo. Em outras palavras, buscar não apenas o que os filmes mostram (seu "conteúdo"), mas como mostram. Uma das características do ativismo gay é a sobreposição das esferas pública e privada: lutamos não apenas para sermos "quem somos", mas para amarmos quem quisermos. Há uma estreita relação entre a luta gay e a esfera do desejo. O desejo pertence à esfera privada. No entanto, ele define quem somos. E isso que "somos" precisa ser verdadeiro tanto para o público quanto para o privado. É por isso que o desejo precisa eventualmente encontrar eco também na esfera pública. Aqui talvez possamos encontrar alguma importância social para os filmes de Warhol — uma importância que resida efetivamente nos filmes e não passe pela pessoa de Warhol, por exemplo em sua reconhecida performatividade queer e afeminada, fora dos padrões em sua época. ${ }^{25}$ Essa importância estaria não apenas nesses filmes como parte de uma história maior de transgressão e liberação, de demolição de uma cultura puritana e heteronormativa, mas em como eles constituem um lugar de identificação por meio da projeção do desejo.

Nosso objetivo aqui é dar conta do olhar, da sensibilidade do cineasta-Warhol. E esse olhar é um olhar essencialmente homossexual. Não por acaso, no momento em que os filmes de Warhol conseguiram extrapolar o ínfimo universo do cinema experimental, foi para encontrar um público majoritariamente gay nos filmes a partir de Chelsea Girls (o que certamente se explica pela explicitação desse "olhar gay", além, claro, da oferta de filmes mais consumíveis, pelo menos na aparência). O curioso é que sempre que os filmes de Warhol apresentam sexo propriamente dito, trocas de carícias explícitas, elas se dão entre homens e mulheres. Lonesome Cowboys, apesar do conteúdo homossexual evidente (o filme termina com dois cowboys abandonando o grupo rumo à Califórnia para

\footnotetext{
${ }^{24}$ Staiger menciona "coberturas" do underground feitas por revistas de grande circulação como a Newsweek e a Life nas quais Warhol constituía, evidentemente, o foco da atenção (2000, pp. 147-148).

${ }^{25}$ Warhol relata em Popismo (2013, p. 22) que, segundo Emile De Antonio, uma das razões que o levavam a não ser aceito em certos círculos de pintores na época era o fato de ele "desmunhecar".
} 
viver um idílio juntos), tem Viva como objeto central de todas as suas cenas de sexo. Bike Boy abre com Joe Spencer tomando banho nu, mas todas as interações visando sexo ocorrem com mulheres. O mesmo vale para I, a Man. My Hustler tematiza abertamente uma relação gay (entre o hustler e seu sugar daddy), mas essa relação permanece exclusivamente no plano do olhar e da fala, sem se consumar fisicamente. A coisa não muda em Flesh, dirigido por Morrissey, em que Joe D'Alessandro se prostitui para arranjar dinheiro para a namorada. Thomas Waugh (1996) fala aqui de um "shotgun approach", sugerindo que esses filmes tentavam contemplar o maior espectro possível de espectadores. Todavia, é difícil imaginar que filmes que exalam uma sexualidade tão gay pudessem agradar a uma plateia hétero: se um público heterossexual ia até esses filmes, ou era movido por interesse artístico ou composto por desavisados. A ausência de sexo gay em filmes claramente gays sem dúvida fala muito mais da repressão do imaginário homossexual na produção de imagens do que de uma mera estratégia comercial.

Os filmes de Warhol surgem num momento em que a produção erótica no cinema ainda era incipiente. Eles vêm antes da liberação de sexo explícito no cinema em 1969, que daria início à chamada "era de ouro" da pornografia nos Estados Unidos. Os anos 1960 serão marcados por uma constante luta entre a produção artística (filmes, publicações, peças) e a censura. Esta, de sua parte, era sempre mais tolerante com a nudez feminina do que com a masculina. Thomas Waugh (1996) relata que a principal forma de consumo homoerótico no cinema nos anos 1950 e 60 era por meio de pequenos filmes rudimentares de curta e média duração, produzidos por figuras como Bob Mizer e Richard Fontaine, exibidos nos chamados cinemas grindhouse na $42^{\mathrm{a}}$ Street, em Nova York. Esses filmes eram muitas vezes estrelados por fisiculturistas, e suas narrativas eram sobretudo um pretexto para o exibicionismo corporal de seus modelos. ${ }^{26}$ Assim, como afirma Waugh, é preciso entender os filmes de Warhol como parte dessa exploração de um território relativamente primitivo, não codificado, na produção de imagens pornográficas, sobretudo homoeróticas. Um primitivismo que, da parte de Warhol, é reforçado pelo fato de ele vir do cinema experimental e underground.

\footnotetext{
${ }^{26}$ Bob Mizer, também editava a famosa revista de fisiculturismo Physique Pictorial, cujo público consumidor era evidentemente gay. Antes de trabalhar para Warhol e Morrissey, Joe D'Alessandro chegou a modelar para a empresa de Mizer.
} 

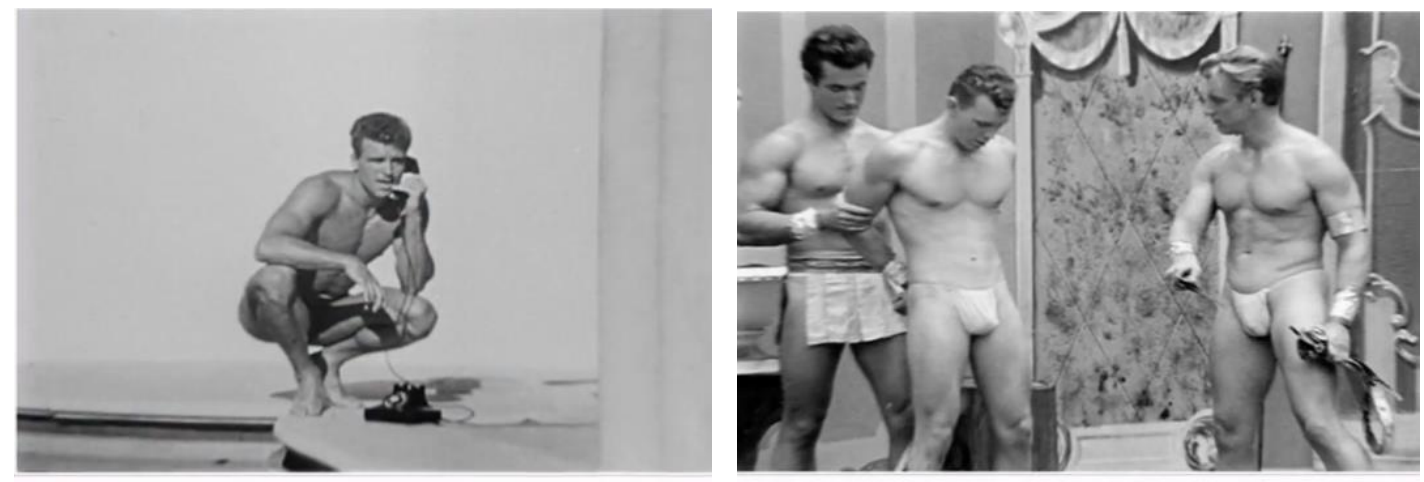

Filmes de Richard Fontaine, que estavam dos raros exemplares de cinema homoerótico nos anos 1950.

A latência e o olhar tateante dos filmes certamente têm a ver com esse contexto. Não tanto no sentido de um Warhol-pornógrafo, que colocava sexo nos filmes até os limites da censura (como Waugh e outros às vezes parecem sugerir). Mas no sentido de que a repressão - da censura estrita, mas também uma repressão formacional de geração, tanto mais forte sobre a homossexualidade, e que, nos escritos de Warhol, assume o ar quase de um recalque em relação ao tema ${ }^{27}$ — também produz um imaginário. A repressão torna excitante o que é proibido. A resposta: sexualizar tudo, impregnar tudo com uma sexualidade latente. A pornografia então causava escândalo: Blow Job é precisamente isto, uma aposta no escândalo. A ideia de pornografia (o "sonho" que se cumpriria em Blue Movie) era excitante para Warhol justamente porque era algo escasso, porque não existia. Hoje a ideia de pornografia é simplesmente banal e violenta. Ela está codificada e é conhecido por todos.

Se a produção de imagens eróticas era incipiente, mais ainda era a ideia de uma consciência artística gay. Os filmes de Warhol são anteriores aos eventos de Stonewall que gerariam, a partir dali, uma nova postura ativista que se faria sentir também na arte, no cinema e na crítica gay. A questão geracional se impõe. Num texto sobre Lonesome Cowboys, Mark Finch fala sobre a dificuldade de "encontrar relações fáceis entre a forma do filme e esse momento crucial na política dos direitos civis" dos anos 1960 (1989, p. 117). Ele fala do aspecto raté do filme, que passeia pelo western, pela pornografia e pelo "filme underground" sem se comprometer com nada. "Lonesome Cowboys é como uma espreguiçadeira na cena do cinema gay; enquanto a pornografia, os ativistas diários e os

\footnotetext{
${ }^{27}$ Warhol, em sua Filosofia (2008): "Deviam mostrar para as crianças, eu sempre pensei, como fazer amor, contar e mostrar para elas de uma vez por todas o nada que é. Mas não fazem isso, porque amor e sexo são business" (p. 57); "Sexo é mais excitante na tela e entre as páginas do que entre lençóis" (p. 58); "Sexo é uma nostalgia para quando você queria fazer sexo" (p. 68); "Depois de estar vivo, a outra coisa mais difícil é fazer sexo" (p. 114).
} 
undergrounders agarram com todas as forças a possibilidade de uma formação política, o filme pula fora de tudo e se recosta". Se o filme "tem uma característica consistente", afirma Finch, "é sua flacidez. Os cowboys se arrastam, seus cavalos vagam pela cidade [...] a trilha sonora alterna entre o audível e o inaudível. Crucialmente, isso não é o mesmo que desmunhecar — é flacidez, não camp" (p. 117).
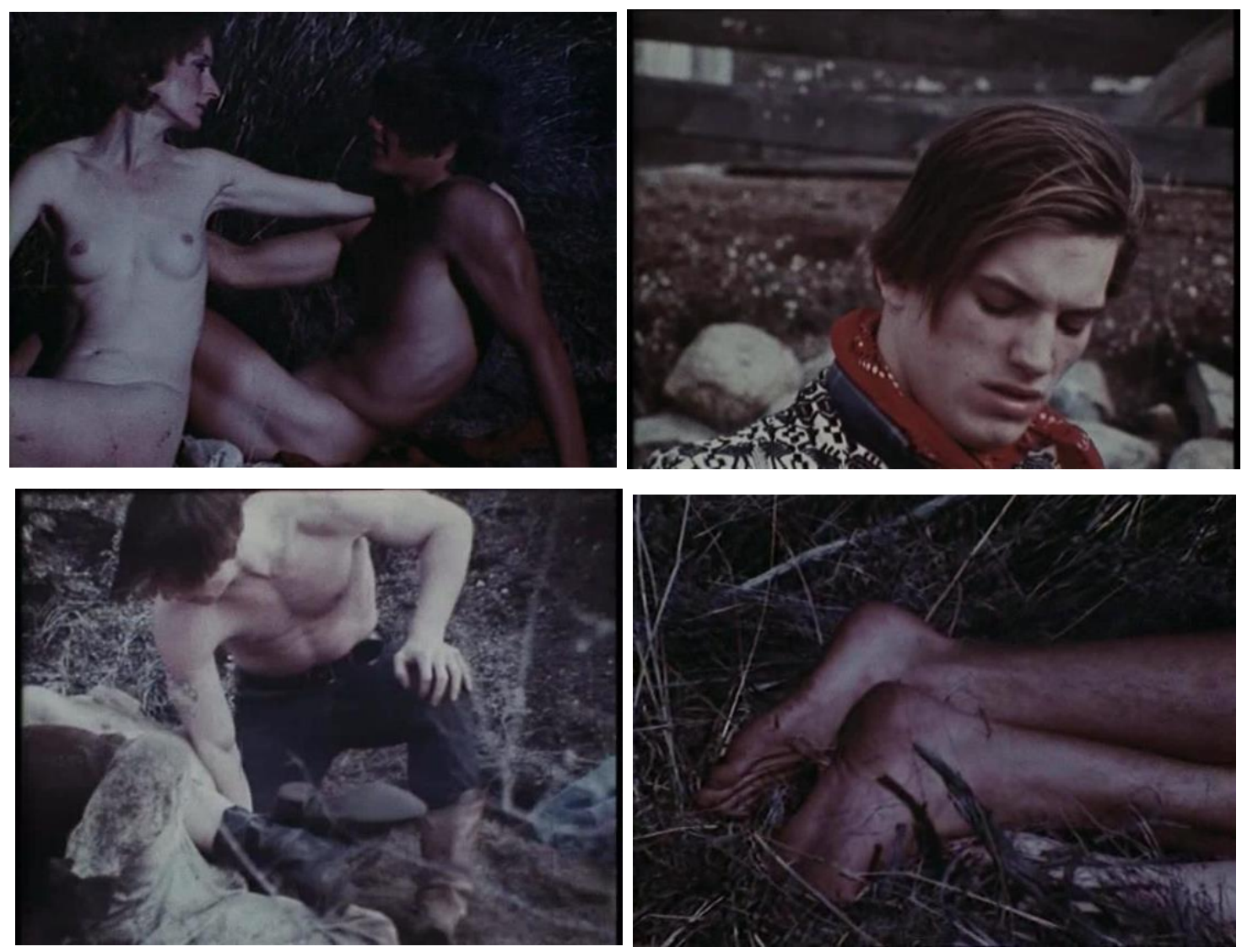

Lonesome Cowboys (1967)

Lonesome Cowboys é um fiasco em muitos sentidos, mas é também o filme mais impregnado por um imaginário gay fetichista de Warhol: os cowboys lutando entre si sem camisa, sua postura blasé ou mesmo ríspida em relação ao sexo feminino (ver a cena do estupro), o show drag do xerife da cidade. Se um olhar gay era perceptível no cinema de Warhol desde Sleep, aqui ele apenas se torna mais explícito ao encontrar seus objetosfetiche, seja o cowboy, seja a figura do biker em Bike Boy. Na realidade, temos a impressão de que esse olhar que encontra seus objetos de desejo é tudo o que resta nesses filmes tardios de Warhol. Em Bike Boy, Warhol põe Joe Spencer tomando banho por dez 
minutos, depois experimentando roupas numa loja. São cenas gratuitas, que só existem para a materialização do fetiche. O desprendimento em relação a qualquer rigor artístico, mas também a qualquer parâmetro comercial, seja narrativo, seja pornô, torna esses filmes uma expressão pura do desejo materializado no fetiche.

Bataille, em sua Teoria do dispêndio, afirma que "os homens asseguram sua subsistência ou evitam o sofrimento [...] para ter acesso à função insubordinada do dispêndio livre" (2013b, p. 61). Warhol leva essa noção de dispêndio ao extremo: todo o seu projeto de cinema é fundado numa gratuidade aberrante. Filmar, registrar, exercer seu olhar sobre as coisas, sem se importar com o resultado, com o "fim". Na realidade, toda a sua obra é fundada no registro "gratuito" daquilo que simplesmente que o atraía (o pop em Warhol é um gesto de positividade, não de reposta negativa), que o fascinava (como Edie Sedgwick), pelas quais ele sentia desejo. É esse desejo circulante que responde em boa parte pela força dos filmes de Warhol. Um desejo em estado puro justamente porque não é assimilável a nenhum tipo de atividade produtiva (narrativa, comercial, pornográfica, política). O filme como uma "espreguiçadeira": Sleep já era também um filme que "se espreguiçava" por mais de cinco horas. O desejo tem qualquer coisa de asocial. A potência dos filmes de Warhol e daqueles de um cineasta como Kenneth Anger, gay como Warhol e contemporâneo a ele, é dar vazão a um desejo puro, não domesticado, assumido em todas as suas potências contraditórias. É isso que assegura a força e a profundidade dessas obras. Em Fireworks (1947), de Anger, a descoberta da sexualidade vem acompanhada pelo pavor de um masoquismo culpado, enquanto em Scorpio Rising o fascínio fetichista pela figura do biker se funde a bizarras alusões ao militarismo e até mesmo ao nazismo. Em Warhol a languidez dá o tom, mas uma languidez enformada pelo voyeurismo, a objetificação e o fetichismo, sendo possível encontrar igualmente referências ao sadomasoquismo em Vinyl e Horse. ${ }^{28}$

Mas hoje o desejo é um problema e um "excedente" indesejável para a crítica e a teoria de cinema. Na maior parte do tempo, preferiríamos que ele não estivesse lá. Em outras épocas, tentou-se imaginar o desejo como força produtiva e mesmo a energia principal no interior da sociedade (Deleuze e Guattari, Lyotard e sua "economia libidinal"). Hoje simplesmente não sabemos o que fazer com ele, exceto eventualmente condená-lo quando assume feições que nos parecem opressivas (objetificação,

\footnotetext{
${ }^{28}$ Um exemplo na arte contemporânea que confrontam o espectador com as ambiguidades do desejo são as obras do artista brasileiro Jonathas Andrade. No cinema, poderíamos pensar igualmente nos filmes do cineasta americano contemporâneo Larry Clark.
} 
fetichização). A presença do desejo trai toda a ideia de um campo artístico fundado na objetividade crítica, na profundidade e no compromisso social. E, no entanto, a relação entre imagem e desejo é das mais profundas que se pode encontrar no nosso inconsciente social.

É significativo nesse sentido que a maioria das releituras dos filmes de Warhol pelo viés dos estudos queer tendam a se concentrar ora em sua faceta camp, ora na importância desses filmes como fenômeno social (sua exibição, censura e o eventual senso de comunidade em torno deles). Thomas Waugh é quem chega mais perto do "problema" do desejo, quando aproxima os filmes de Warhol das produções eróticas de Fontaine e Mizer e afirma que "pornografia, pura e simplesmente, é o contexto indispensável para entender os filmes" de Warhol (1996, pp. 64-65) — embora aí também haja a tendência de compreender os filmes como fato social, como exercício de gênero voltado para um público. É evidente que essa tendência não é prerrogativa dos estudos queer: trata-se antes de uma tendência dos estudos culturais em geral. O fato é que frequentemente a crítica dos filmes de Warhol, tanto em sua faceta "hétero" quanto nos estudos queer, ao se defrontar com a figura do desejo, tende a alternar entre duas posturas: ignorá-lo solenemente ou tentar instrumentalizá-lo.

Um caso que fica entre uma opção e outra é o texto de Douglas Crimp, citado acima, que procura reler os filmes de Warhol por um viés emancipador. Baseado na reconhecida indistinção moral de Warhol entre alta e baixa cultura, "profundidade e superfície", "realidade e artifício e alta sociedade e submundo" (JAMES apud CRIMP, p. 11), ele vê os filmes de Warhol como encarnação de um paradigma "estético-ético" de aceitação do Outro e de sua individualidade, onde todos "apenas são" ("They simply are") diante da câmera. Aqui, Crimp parece comprar a versão de Warhol de que seus filmes apenas mostravam as pessoas "fazendo o que sempre fizeram - ser elas mesmas". O cinema de Warhol se torna um reino ético universal do acolhimento absoluto da diferença. Há uma clara tentativa de positivar os filmes e afirmar Warhol como um "cineasta progressista". E quando o desejo entra na equação, é como possibilidade emancipadora: em Mario Banana, Crimp afirma, o personagem controla a cena na medida em que nos olha diretamente nos olhos, exercendo poder sobre nós. Um personagem emancipado, portanto. Embora sensível, a análise não responde pelo todo da obra de Warhol. Crimp afirma, citando David James, que "Warhol recusa a possessão autoral" daqueles que filma. Ora, a hipótese de uma possessão autoral do mundo é justamente o que move este trabalho: tentar afirmar que os filmes de Warhol impõem, sim, um olhar sobre o que 
filmam, que eles operam, desde os primeiros filmes, transformando tudo em superfície, chegando ao "corpo puro", sexualizando tudo, fazendo circular, por fim, um desejo nas imagens. Tratava-se de afirmar que a máquina, apesar de sua debilidade e aparente indiferença, possui um olhar. O problema do texto de Crimp é fechar os olhos para um desejo ambíguo, carregado de contradições (fascinação, objetificação, perversidade) em favor de uma leitura ética assepsiada de Warhol, na qual tudo está no seu lugar certo, devidamente acolhido e aceito.

\section{Blue Movie}

Como vimos, o sexo sempre animou os filmes de Warhol desde o início. Mas em algum momento ele finalmente chegaria à sua concretização literal: em Blue Movie, o primeiro filme de Warhol com cenas de sexo explícito a efetivamente circular - Couch, que também continha cenas explícitas, teve apenas exibições privadas. Blue Movie foi realizado após a tentativa de assassinato de Warhol por Valerie Solanas, em junho de 1968, que marca uma mudança significativa em sua carreira. Enquanto se recuperava das lesões provocadas pelo tiro, Warhol montou Lonesome Cowboy, que foi lançado nos cinemas próximo a Flesh, de Morrissey. Mas Blue Movie, contrariando a tendência das produções desde 1967, é dirigido apenas por Warhol, com Morrissey sendo creditado apenas como produtor. Isso é nítido - e decisivo - no filme. ${ }^{29}$

Blue Movie é todo Warhol. Muito longe de ser o ponto final de uma trajetória de concessão ao sensacionalismo e ao cinema comercial, o filme recupera todos os procedimentos caros a Warhol: o isolamento espacial, o despojamento da cena, a contiguidade dos corpos em relação à câmera, a duração prolongada, que aqui não exatamente excede a cena (como Eat, Drink, Sleep), mas tenta se colocar no ritmo da vida. Warhol (2013, p. 350), não à toa, dirá que depois de fazer filmes sobre pessoas comendo, dormindo e beijando chegara o momento de finalmente fazer um filme com apenas "sexo". No entanto, a tal cena de sexo propriamente dito ocorre em apenas um dos quatro rolos com cerca de 33 minutos que compõem o filme. Assim, "sexo", estritamente

\footnotetext{
${ }^{29}$ A única cópia de Blue Movie a que tivemos acesso estava dublada em alemão, o que prejudicou bastante nossa compreensão em relação ao que é dito pelos atores e seu estilo de atuação. Uma noção geral dos assuntos das conversas foi dada por relatos do filme. Ainda assim, nossa relação com a obra foi, infelizmente, amputada para um plano essencialmente visual, dado pelas posturas dos corpos e sua relação com a câmera.
} 
falando, constitui 1/4 do filme, embora seus efeitos estejam impregnados no filme inteiro, como sempre em Warhol.

Acima de tudo, a operação de Blue Movie é colocar o sexo no tempo. O primeiro rolo é feito todo de preparações: Viva e Louis Waldon apenas conversam, se tocam, se aproximam. Há cortes nesse rolo, strobe cuts, como nos outros filmes dessa "fase". A ele segue-se então o segundo rolo, no qual o ato sexual acontece. Esse rolo de cerca de 30 minutos é filmado numa única tomada, sem mudanças de enquadramento, sugerindo que a equipe talvez tenha se retirado do quarto para a cena. Os atores em alguns momentos parecem se "autodirigir", ora com Viva dizendo para Waldon deixar de "mostrar o pênis e as bolas para a câmera", ora com uma mudança de posição de ambos, para que fiquem horizontais ("de perfil") em relação à câmera. O sexo de fato dura menos de dez minutos e ocorre na segunda metade do rolo. Ao longo da cena, Viva e Waldon alternam entre momentos de autoconsciência irônica diante da câmera, como que para dissipar o nervosismo e o constrangimento, e outros em tentam se concentrar nas carícias para fazer a cena acontecer - num desses momentos, antes do ato, a campainha toca e os dois interrompem as carícias surpresos. Até que a penetração começa, mas pouco vemos: a câmera permanece à distância, num plano geral que capta toda a cama, de forma que observamos um pouco de tudo e um pouco de nada do papai-e-mamãe protagonizado pelos atores. A ausência de decupagem, de uma alternância de posições, de expressões, poses e posturas cria uma imagem muito diferente da codificação pornográfica: apenas duas massas, uma sobre a outra, banhadas pela mesma luz homogênea (o título Blue Movie se refere a um banho azul que o filme recebeu por erro na pós-produção, mas a cópia hoje disponível tende ao amarelo). E, muito mais do que transar, seja neste, seja nos outros rolos do filme, como é típico em Warhol, Viva e Waldon falam: fala, falam e falam sem parar.

Assim, passado o rolo em que transcorre o ato sexual, há ainda mais dois: mais 1 h15 de filme em que Viva e Waldon conversam nus, leem uma revista, assistem TV, comem hambúrgueres, se vestem, Viva sai, Waldon assiste ao pôr do sol, Viva volta e os dois cozinham e, finalmente, tomam banho juntos. A construção aqui é novamente anticlimática, porém de um modo inverso ao de Blow Job: a obrigação do sexo é cumprida logo de cara para "liberar" o filme. A motivo puro que Warhol quer isolar não é exatamente aquele do sexo, mas as poses e posturas de um casal - o que inclui o sexo, mas não só - numa tarde compartilhada, apartada do mundo, fechada em si mesma numa particularidade objetiva universal. 
O corpo é o mundo no cinema de Warhol. Em Sleep, os enquadramentos amplificavam e monumentalizam o corpo de John Giorno: os plongeés e contra-plongées sobre aquela estátua horizontal desacordada tornavam cada recorte do corpo um fragmento genérico e comum. A monumentalização cria um sentido cósmico: não precisamos sair do corpo de um homem para ter o mundo inteiro, como numa espécie de atomismo. Tudo está lá. Sua respiração é a respiração do universo. O corpo nu e anônimo se torna a um só tempo uma entidade impessoal e um elo absoluto: apenas a vida reduzida a seus sinais vitais. Os diversos estudos sobre a pele feitos por Warhol (a pele de Robert Indiana, em Eat; os poros de Giorno, em Sleep) fazem de seus filmes uma busca em expansão, obsessiva, por esse tecido de que somos todos feitos e cujo apelo erótico se dá indiferentemente de qualquer codificação sexual: apenas a pura matéria da pele, impressa sobre o grão da película, na qual projetamos nosso desejo por meio do dispositivo maquínico, nossa prótese. 

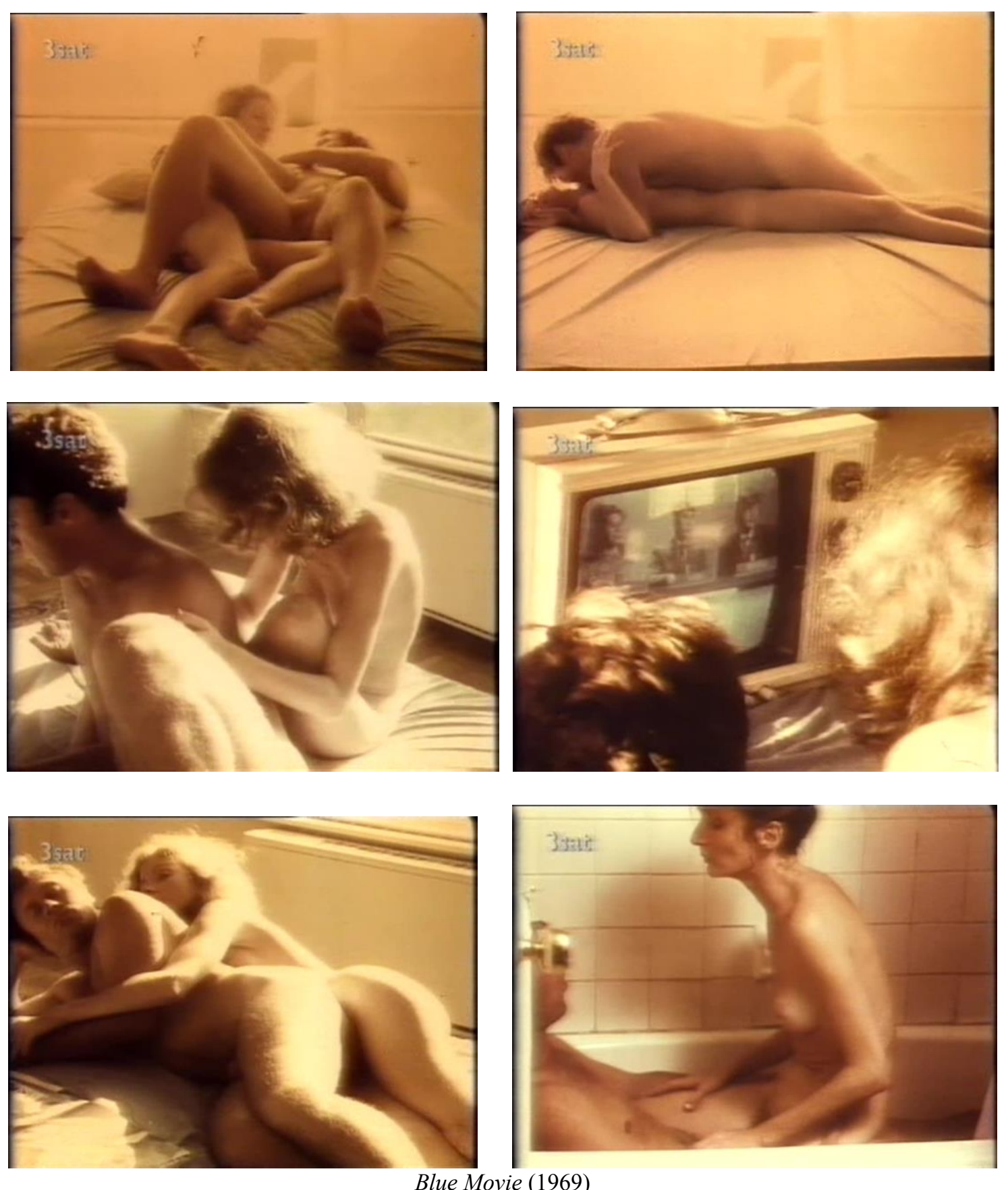

Blue Movie (1969) 


\section{Considerações finais}

De muitas maneiras, os filmes de Warhol testam os limites do cinema. Eles testam em sua duração, na flacidez das performances, na equiparação do filme à sua estrutura material (o rolo de película), no seu desinteresse geral em criar obras consistentemente acabadas. A própria ideia - que ainda e cada vez mais pauta a existência do cinema da obra de arte como mônada, universo fechado dotado de articulações internas que expressa um todo coerente e orgânico, entra em crise diante dos filmes de Warhol. Adriano Aprà e Enzo Ungari, já em 1971, falavam da dificuldade de analisar esses filmes a partir de um repertório crítico centrado em noções como 'a 'mensagem', a 'ideia', o 'projeto', o 'estilo, o 'conteúdo', a ‘forma'”. Em Warhol, o filme frequentemente se torna um processo (GIDAL, 1989, pp. 51-60), uma experiência que se imprime na película na forma de espaço-tempo. Ou, melhor, para retomar a expressão de Peter Wöllen (1998, p. 115) mencionada na introdução, o filme é um artefato, um objeto a partir do qual podemos intuir a sensibilidade do artista.

Nesse sentido, sugerimos ao longo deste trabalho que os filmes de Warhol se dão numa dialética entre dois polos: a máquina e o corpo, que também podem ser entendidos como o jogo entre a instância que "olha" e aquela que "é olhada". Essa duplicidade pode assumir outras formas e receber outros nomes, a depender dos aspectos que se queira ressaltar. Peter Wöllen (1989, p. 17), como vimos, fala dos filmes de Warhol nos termos de uma dialética entre o minimalismo e o camp, entre a austeridade formal e a orgia da performance. Poderíamos igualmente ver neles uma dialética entre, de um lado, um cinema estrutural-materialista (segundo as perspectivas de Gidal e Sitney) e, de outro, a inocência lumièriana recuperada (Mekas). Ou entre o registro industrial da máquina e o cotidiano banal, entre o inorgânico e o orgânico, entre o olho de vidro impassível da câmera e o desejo. Ou poderíamos, ainda, ver outra dialética fundamental em Warhol: aquela entre a estaticidade e o tempo.

Todas essas questões atravessam o "mais simples aparelho", para recuperar uma expressão de Dominique Païni (1997, p. 91), dos filmes de Warhol. No entanto, elas são questões de fundo, latentes nesse aparelho. Em uma visão mais imediata, os filmes continuam a ser pura e simplesmente sobre pessoas, sobre registrar pessoas diante da câmera. Em outras palavras, a polarização entre máquina e corpo não é colocada explicitamente pelos filmes em seu interior e resolvida de um ponto de vista temáticoformal. Ela é algo que antecede a obra, é a própria estrutura da sensibilidade do autor. $\mathrm{O}$ 
fato de os filmes não refletirem conscientemente sobre esses elementos talvez explique por que nem sempre é fácil conciliar os dois polos. A máquina, o estilo máquínico de Warhol, representa um corte irrecuperável, uma cisão que nos aliena do mundo. Quando ele encontra o tema da morte, da mercadoria ou da fantasmagoria do ícone em suas telas mais famosas dos anos 1960, parece haver aí uma conciliação temático-formal. No entanto, quando a máquina se volta para o eros, para o vivo e para a espalhafatosidade camp, não temos mais a mesma certeza de onde estamos pisando. Mas essa nãoconciliação também pode ser produtiva na medida em que consegue criar tensões entre as coisas. Nos filmes de Warhol, a máquina, através do dispositivo, produz transformações no corpo, ela obriga o corpo a performar, cria coisas, deseja esse corpo (ainda que de forma latente).

Resta, por fim, uma questão: Warhol fez cinema? Seus filmes são cinema? ${ }^{1}$ Que lugar eles ocupam no percurso da arte do século XX? Em primeiro lugar, não estou certo de que a categorização de uma obra precise ser exclusiva, isto é, que uma obra seja essencialmente uma coisa e não possa ser olhada, de um outro ponto de vista, como outra. Assim, não é evidente que, se reivindico os filmes de Warhol para o cinema, estou retirando-os, ipso facto, de outro lugar. Isso é um primeiro ponto. A favor do cinema, no entanto, poderíamos argumentar com o contexto histórico em que os filmes de Warhol despontam: o fato de que eles surgem no seio do cinema independente e de vanguarda norte-americano dos anos 1950 e 60 e como o impulso de Warhol para os filmes parece responder a um anseio pelo imaginário e pelo mito do cinema, por tudo o que ele representava então - discutimos um pouco essas questões na introdução, quando falamos do aproximação de Warhol em direção ao cinema.

Aqui, no entanto, gostaria de me deter no seguinte: o cinema precisa dos filmes de Warhol tanto quanto os filmes de Warhol precisam do cinema. O cinema precisa dos filmes de Warhol porque eles "testam" e recolocam questões sobre os seus limites; o cinema certamente ficaria mais magro e menos interessante sem os filmes de Warhol. E os filmes de Warhol "precisam" do cinema porque lá podem encontrar um tipo de espectatorialidade à sua altura. Uma espectatorialidade pautada na confrontação a partir da captura do tempo do espectador, muito diferente, portanto, da flanagem da galeria. Dito de outra forma, embora os filmes de Warhol possam ser perfeitamente exibidos galerias, videoinstalações e mesmo em saguões com um sentido puramente decorativo

\footnotetext{
${ }^{1}$ Essa pergunta-provocação me foi colocada pelo cineasta e pesquisador Carlos Adriano em minha banca de qualificação. Deixo aqui meu agradecimento a ele.
} 
(e o próprio Warhol certamente seria o último a censurar qualquer uma dessas formas), eles só têm a ganhar quando exibidos no cinema. Isso não implica, como dissemos antes, num exclusivismo: é apenas um argumento no imenso debate sobre o que esses filmes oferecem para nós e o que podemos fazer por eles. Sobre o que eles efetivamente criam e o que nós - como espectadores, críticos, pesquisadores, curadores e exibidores — podemos criar com eles. 


\section{Referências bibliográficas}

ANGELL, Callie. Something Secret: Portraiture in Warhol's Films. Sidney: Museum of Contemporary Art, 1994a

. The Films of Andy Warhol: Part II. Nova York: Whitney Museum of American Art, 1994b

APRÀ, Adriano. UNGARI, Enzo. Il cinema di Andy Warhol, Arcana, Roma 1971. Alguns trechos desse livro foram publicados por Adriano Aprà em seu site pessoal: http://www.adrianoapra.it/?p=1504 e http://www.adrianoapra.it/?p=1528, acesso em 02 de julho de 2017.

BARBOSA, André Antônio. Constelações da frivolidade no cinema brasileiro contemporâneo. Tese de doutorado. Rio de Janeiro: ECO/UFRJ, 2017.

BARTHES, Roland. A câmara clara: nota sobre a fotografia. Rio de Janeiro: Nova Fronteira, 2015

BATAILLE, Georges. O erotismo. Belo Horizonte: Autêntica Editora, 2013a . A parte maldita, precedida de "A noção de dispêndio". Belo

Horizonte: Autêntica Editora, 2013b

BAUDELAIRE, Charles. Sobre a modernidade. São Paulo: Paz e Terra, 2002.

BAUDRILLARD, Jean. "A arte da desaparição", in BAUDRILLARD, Jean. MACIEL, Kátia (org.). A arte da desaparição. Rio de Janeiro: Editora UFRJ, 2017.

BENHAMOU-HUET, Judith (org.). Warhol TV. Rio de Janeiro: Aeroplano, 2011. Catálogo da retrospectiva do Oi Futuro.

BERG, Gretchen. "Nothing to Lose: An Interview with Andy Warhol" [entrevista], in O'PRAY, Michael (org.). Andy Warhol: Film Factory. Londres: BFI, 1989, pp. 54-61.

BOCKRIS, Victor. Warhol: The Biography. Cambridge (MA): Da Capo Press, 2003. Ebook.

BRAKHAGE, Stan. "Metáforas da visão". Trad. Ismail Xavier e João Luiz Vieira, in XAVIER, Ismail (org.). A experiência do cinema, 1983. Rio de Janeiro: Edições Graal: Embrafilme, 1983, pp. 341-352.

BRESSANE, Julio. Deslimite. Rio de Janeiro: Imago, 2011. 
BUCHLOH, Benjamin. “Andy Warhol's One-Dimensional Art: 1956 - 1966”, in MICHELSON, Annette (org.). Andy Warhol (October Files 2). Cambridge:

Massachusetts Institute of Technology, 2001. Andy Warhol - Shadows and Other Signs of Life. Colônia (Alemanha): Verlag der Buchhandlung Walther König, 2008.

CRIMP, Douglas. "Our Kind of Movie”: the films of Andy Warhol. Cambridge/ Londres: The MIT Press, 2012. E-book.

DE DUVE, Thierry. "Andy Warhol, or The Machine Perfected”, in October, vol. 48 (Primavera, 1989), pp. 3-14.

DE HAAS, Patrick. Andy Warhol: Le Cinéma comme "braille mental". Paris: Éditions Paris Expérimental, coleção Les Cahiers de Paris Expérimental, 2005.

DELAHAYE, Michael. "Andy: La mise à nu", in Cahiers du Cinéma n $^{0} 205$, outubro de 1968.

DELEUZE, Gilles. Cinema 2: A imagem-tempo. São Paulo: Brasiliense, 2005.

DUARTE, Theo. "O cinema estrutural norte-americano (1965-1972): sobre os debates em torno do termo", in DUARTE, Theo; MOURÃO, Patrícia (orgs.). Cinema estrutural. Rio de Janeiro: Aroeira, 2015, pp. 42-61.

DUARTE, Theo. O cinema de vanguarda em diálogo com as artes visuais: contrastes e paralelos em experiências brasileiras e norte-americanas (1967-1971). Tese de doutorado. São Paulo: ECA/USP, 2017.

EPSTEIN, Jean. Écrits sur le cinéma: 1921-1947. Tome 1: 1921-1947. Paris : Éditions Seghers, 1974.

FRANCIS, Mark. POP. Londres/ Nova York: Phaidon,, 2005.

FINCH, Mark. "Rio Limpo: 'Lonesome Cowboys' and Gay Cinema”, in O'PRAY, Michael (org.). Andy Warhol: Film Factory. Londres: BFI, 1989, pp. 112-117.

FOSTER, Hal. O retorno do real: a vanguarda no final do século XX. São Paulo: Cosac Naify, 2014.

FOSTER, Hal. “Survey”, in FRANCIS, Mark. POP. Londres/ Nova York: Phaidon,, 2005, pp. 14-41. 
FREUD, Sigmound. "Três ensaios sobre a teoria da sexualidade", in Obras completas, volume VII. Um caso de histeria, três ensaios sobre a teoria da sexualidade e outros trabalhos (1901-1905). Rio de Janeiro: Imago, 2007.

FRIED, Michael. "Arte e objetidade", in Arte \& Ensaios, no. 9. Rio de Janeiro: PPGAV/EBAUFRJ, 2002.

GELDZAHLER, Henry. "Some Notes on 'Sleep'”, in Film Culture n' 32, primavera de 1964, p. 13.

GIDAL, Peter. Materialist Film. Londres / Nova York: Routledge, 1989. Andy Warhol: Films and Paintings: The Factory Years. Nova York: Da Capo Press, 1991.

JAMES, David. “The Producer as Author", in O'PRAY, Michael (org.). Andy Warhol: Film Factory. Londres: BFI, 1989, pp. 136-145.

JAMESON, Frederic. Pós-modernismo: a lógica cultural do capitalismo tardio. Trad. Maria Elisa Cevasco. São Paulo: Ática, 2007.

JUDD, Donald. "Objetos específicos", in FERREIRA, Glória; COTRIM, Cecilia (orgs.). Escritos de artistas: Anos 60/70. Rio de Janeiro: Jorge Zahar, 2006.

KOCH, Stephen. Stargazer: The Life, World and Films of Andy Warhol, Nova York/ Londres: Marion Boyars, 2002.

LEE, Pamela L. Chronophobia: On Time in the Art of the 1960s. Cambridge/ Londres: The MIT Press, 2004.

LEON, Benjamin. "Composer la lumière para le corporel dans le cinema de Andy Warhol", in La Furia Umana. Link http:/www.lafuriaumana.it/index.php/2uncategorised/94-benjamin-leon-composer-la-lumiere-par-le-corporel-dans-le-cinemad-andy-warhol, acesso em 02 de julho de 2017.

MEKAS, Jonas. “Sixth Independent Film Award”, in Film Culture no 33, 1964.

MEKAS, Jonas; MOURÃO, Patrícia (org.). Jonas Mekas. São Paulo: Centro Cultural Banco do Brasil; Pró-reitoria de Cultura e Extensão Universitária — USP, 2013.

MESQUITA, Tiago. Através do espelho: a constituição da pintura inicial de Andy Warhol (1956 - 1968). Dissertação de mestrado. São Paulo: FFLCH/USP, 2009. 
MIGLIORIN, Cezar. "O dispositivo como estratégia narrativa", in Digitagrama $\mathrm{n}^{\circ}$ 3, primeiro semestre de 2005. Link:

http://www.estacio.br/graduacao/cinema/digitagrama/numero3/cmigliorin.asp, acesso em 02 de julho de 2017.

MICHELSON, Annette. "Em direção a Snow". Trad. Joaquim Toledo Jr., in DUARTE, Theo; MOURÃO, Patrícia (orgs.). Cinema Estrutural. Rio de Janeiro: Aroeira, 2015, pp. 178-195.

MURPHY, J.J. The Black Hole of the Camera: The Films of Andy Warhol. Londres/ Berkeley/ Los Angeles: University of California Press, 2012.

OLIVEIRA JR., Luiz Carlos. "Retratos em movimento", in Anais do XXIV Compós: Brasília/DF, 2015. Link: http:/www.compos.org.br/biblioteca/compos-2015-64b6f039ab85-4109-8b55-0be33e3f46cc_2842.pdf, acesso em 02 de julho de 2017.

O’PRAY, Michael (org.). Andy Warhol: Film Factory. Londres: BFI, 1989.

PAÏNI, Dominique. Le Cinéma, un art moderne. Paris: Cahiers du Cinéma, 1997.

PERNIOLA, Mario. O sex appeal do inorgânico. Trad. Nilson Moulin. São Paulo: Studio Nobel, 2005.

RANCIÈRE, Jacques. As distâncias do cinema. Rio de Janeiro: Contraponto, 2012.

RAYNS, Tony. "Death at work: Evolution and Entropy in Factory Films", in O'PRAY, Michael (org.). Andy Warhol: Film Factory. Londres: BFI, 1989, pp. 160-169.

RENOIR, Jean. "Contrato dos diretores", in Escritos sobre cinema, 1926-1971. Rio de Janeiro: Nova Fronteira, 1990.

SCHECHNER, Richard. "O que é performance?", in O Percevejo, Revista de teatro, crítica e estética, ano 11, $\mathrm{n}^{\circ} 12,2003$.

SHARITS, Paul. "Palavras por página”. Trad. Luís Felipe Flores, in DUARTE, Theo; MOURÃO, Patrícia (orgs.). Cinema Estrutural. Rio de Janeiro: Aroeira, 2015.

SHAVIRO, Steven. "The Life, After Death, of Postmodern Emotions" in Criticism, v. 46, n. 1, p. 125- 141. Wayne State University Press: 2004. O corpo cinemático. Trad. Anna Fagundes. São Paulo: Paulus, 2015.

SITNEY, P. Adams. Visionary Film: The American Avant-Garde, 1943-2000. Nova 
York: Oxford University Press, 2002.

SMITH, Patrick S. Andy Warhol's Art and Films. Ann Arbor: UMI Research Press, 1981.

SONTAG, Susan. "A imaginação pornográfica”, in $A$ vontade radical. Rio de Janeiro: Cia. das Letras, 1987a.

L\&PM, 1987. pp. 318-337. "Notas sobre o camp", in Contra a interpretação. Porto Alegre:

STAIGER, Janet. Perverse Spectators: The Practices of Film Reception. Nova York/ Londres: New York University Press, 2000.

WALL, Jeff. "Marcas da indiferença", Trad. Denise Bottmann, in Revista ZUM, n 12, abril de 2017

WARHOL, Andy. A filosofia de Andy Warhol: de A a B e de volta a A. Trad. José Rubens Siqueira. Rio de Janeiro: Cobogó, 2008.

WARHOL, Andy; HACKETT, Pat. Popismo: os anos sessenta segundo Andy Warhol. Trad. José Rubens Siqueira. Rio de Janeiro: Cobogó, 2013.

WAUGH, Thomas. "Cockteaser”, in DOYLE, Jennifer; FLATLEY, Jonathan; MUÑOZ, Esteban (orgs.). Pop Out: Queer Warhol. Durham/ Londres: 1996.

WÖLLEN, Peter. "Raiding the Icebox", in O'PRAY, Michael (org.). Andy Warhol: Film Factory. Londres: BFI, 1989, pp. 14-27. . Signs and Meaning in the Cinema. Londes: BFI, 1998.

VERTOV, Dziga. "Resolução do conselho dos três em 10-4-1923". Trad. Marcelle Pithon, in XAVIER, Ismail (org.). A experiência do cinema, 1983. Rio de Janeiro: Edições Graal: Embrafilme, 1983, pp. 252-259. 


\section{Filmografia}

Este é um pequeno apanhado dos filmes dirigidos por Warhol ordenados por seu ano de filmagem. Ele está longe de uma filmografia completa. Contemplamos basicamente os filmes mencionados neste trabalho, acrescidos de alguns poucos outros - a maior parte filmes que não pudemos assistir por falta de cópias disponíveis, mas cujos relatos em livros e textos nos sugerem que esses filmes podem ter relevância. Screen Tests não estão listados. Nosso objetivo é dar apenas um vislumbre da produção cinematográfica de Warhol. Filmes com projeção a 16 fotogramas por segundo estão indicados entre parênteses.

\section{3}

Kiss (1963-64) 16mm.. P/B. Silencioso. 54 min. (16 fps)

Eat (1964) 16mm.. P/B. Silencioso. 39 min. (16 fps)

Haircut (No. 1) (1963) 16mm. P/B. Silencioso. 27 min. (16 fps)

Tarzan and Jane Regained... Sort Of (1963) 16mm. P/B e Cor. Som. $80 \mathrm{~min}$.

Sleep (1963) 16mm. P/B. Silencioso. 5 hr. 21 min. (16 fps)

\section{4}

Blow Job (1964) 16mm. P/B. Silencioso. $41 \mathrm{~min}$. (16 fps)

Couch (1964) 16mm. P/B. Silencioso. $58 \mathrm{~min}$. (16 fps)

Empire (1964) 16mm. P/B. Silencioso. 8 hr. 5min. (16 fps)

Harlot (1964) 16mm. P/B. Som. $66 \mathrm{~min}$.

Henry Geldzahler (1964) 16mm. P/B. Silencioso. 99 min. (16 fps)

Mario Banana \# 1 (1964) 16mm. Cor. Silencioso. 4 min. (16 fps)

Mario Banana \# 2 (1964) 16mm. P/B. Silencioso. 4 min. (16 fps)

Shoulder (1964) 16mm. P/B. Silencioso. 4 min. (16 fps)

Soap Opera (1964) 16mm. P/B. Som. $47 \mathrm{~min}$.

\section{5}

Beauty \# 2 (1965) 16mm. P/B. Som. $66 \mathrm{~min}$.

Camp (1965) 16mm. P/B. Som. $66 \mathrm{~min}$.

Horse (1965) 16mm. P/B. Som. $100 \mathrm{~min}$.

Kitchen (1965) 16mm. P/B. Som. $66 \mathrm{~min}$.

My Hustler (1965) 16mm P/B. Som. $67 \mathrm{~min}$.

Poor Little Rich Girl (1965) 16mm. P/B. Som. 66 min.

Screen Test \# 1 (1965) 16mm. P/B. Som. 66 min.

Screen Test \# 2 (1965) 16mm. P/B. Som. 66 min. 
The Life of Juanita Castro (1965) 16mm. P/B. Som. $66 \mathrm{~min}$.

Vinyl (1965) 16mm. P/B. Som. $67 \mathrm{~min}$.

\section{6}

The Chelsea Girls (1966) 16mm. P/B and Cor. Som. 204 min. (dupla projeção)

Eating Too Fast (1966) 16mm P/B. Som. 66 min.

Hedy (1966) 16mm. P/B. Som. $66 \mathrm{~min}$.

\section{7}

Bike Boy (1967) 16mm. Cor. Som. $109 \mathrm{~min}$.

I, a Man (1967) 16mm. Cor. Som. 95 min.

The Loves of Ondine (1967-68) 16mm. Cor. Som. 85 min.

The Nude Restaurant (1967) 16mm. Cor. Som. $100 \mathrm{~min}$.

\section{8}

Lonesome Cowboys (1968) 16mm. Cor. Som. 109 min.

San Diego Surf (1968) 16mm. Cor. Som. 90 min.

Blue Movie (1968) 16mm. Cor. Som. $133 \mathrm{~min}$. 